Invited review

\title{
Differences between the last two glacial maxima and implications for ice-sheet, $\delta^{18} \mathrm{O}$, and sea-level reconstructions
}

\author{
Eelco J. Rohling a, b, *, 1 , Fiona D. Hibbert ${ }^{\text {a, }}{ }^{\text {, Felicity H. Williams }}{ }^{\text {a, b, } 1}{ }^{\text {, Katharine M. Grant }}{ }^{\text {a }}$, \\ Gianluca Marino a, Gavin L. Foster ${ }^{\text {b}}$, Rick Hennekam ${ }^{\text {c, d }}$, Gert J. de Lange ${ }^{\mathrm{d}}$, \\ Andrew P. Roberts ${ }^{a}$, Jimin Yu ${ }^{\mathrm{a}}$, Jody M. Webster ${ }^{\mathrm{e}}$, Yusuke Yokoyama ${ }^{\mathrm{f}, \mathrm{g}, \mathrm{h}}$ \\ ${ }^{a}$ Research School of Earth Sciences, The Australian National University, Canberra, ACT 2601, Australia \\ b Ocean and Earth Science, University of Southampton, National Oceanography Centre, Southampton SO14 3ZH, UK \\ ${ }^{c}$ Department of Ocean Systems, Royal Netherlands Institute for Sea Research (NIOZ), Utrecht University, PO Box 59, 1790 AB Den Burg, Texel, The \\ Netherlands \\ ${ }^{\mathrm{d}}$ Department of Earth Sciences-Geochemistry, Faculty of Geosciences, Utrecht University, Utrecht, The Netherlands \\ e School of Geosciences, The University of Sydney, NSW 2006, Australia \\ ${ }^{\mathrm{f}}$ Atmosphere and Ocean Research Institute, The University of Tokyo, 5-1-5 Kashiwanoha, Chiba 277-8564, Japan \\ g Department of Earth and Planetary Science, Graduate School of Science, The University of Tokyo, 7-3-1 Hongo, Bunkyoku, Tokyo 113-0033, Japan \\ ${ }^{\mathrm{h}}$ Department of Biogeochemistry, Japan Agency for Marine-Earth Science and Technology, 2-15 Natsushimacho, Yokosuka 237-0061, Japan
}

\section{A R T I C L E I N F O}

\section{Article history:}

Received 8 May 2017

Received in revised form

31 August 2017

Accepted 20 September 2017

Available online 10 October 2017

\section{Keywords:}

Last Glacial Maximum

Penultimate Glacial Maximum

Sea level

Ice volume

$\delta^{18} \mathrm{O}$

Arctic ice shelf

Last Interglacial

Glacioisostatic adjustment

\begin{abstract}
A B S T R A C T
Studies of past glacial cycles yield critical information about climate and sea-level (ice-volume) variability, including the sensitivity of climate to radiative change, and impacts of crustal rebound on sealevel reconstructions for past interglacials. Here we identify significant differences between the last and penultimate glacial maxima (LGM and PGM) in terms of global volume and distribution of land ice, despite similar temperatures and radiative forcing. Our analysis challenges conventional views of relationships between global ice volume, sea level, seawater oxygen isotope values, and deep-sea temperature, and supports the potential presence of large floating Arctic ice shelves during the PGM. The existence of different glacial 'modes' calls for focussed research on the complex processes behind ice-age development. We present a glacioisostatic assessment to demonstrate how a different PGM ice-sheet configuration might affect sea-level estimates for the last interglacial. Results suggest that this may alter existing last interglacial sea-level estimates, which often use an LGM-like ice configuration, by several metres (likely upward).
\end{abstract}

() 2017 Elsevier Ltd. All rights reserved.

\section{Introduction}

The volume and spatial distribution of continental ice masses during ice ages over the last 3 million years have been the focus of much research for several reasons. First, temporal changes in the radiative balance of climate are important because ice masses have high albedo and reflect incoming solar radiation (e.g., Hansen et al., 2007, 2008; Köhler et al., 2010, 2015; Rohling et al., 2012; PALAEOSENS project members, 2012; Martínez-Botí et al., 2015;

\footnotetext{
* Corresponding author. Research School of Earth Sciences, The Australian National University, Canberra, ACT 2601, Australia.

E-mail address: eelco.rohling@anu.edu.au (E.J. Rohling).

1 Joint first authors.
}

Friedrich et al., 2016). Second, temporal development of ice-age cycles provides critical information about the nature of long-term climate cooling over the past few million years, in response to $\mathrm{CO}_{2}$ reduction and interactions among ice, land cover, and climate (e.g., Clark et al., 2006; Köhler and Bintanja, 2008; de Boer et al., 2010, 2012; Hansen et al., 2013). Third, variable amplitude of individual ice ages helps to determine the relationship between climate change, astronomical climate forcing cycles, and climate feedbacks on timescales of 10s-100s of kiloyears (e.g., Oglesby, 1990; Imbrie et al., 1993; Raymo et al., 2006; Colleoni et al., 2011, 2016; Ganopolski and Calov, 2011; Carlson and Winsor, 2012; Abe-Ouchi et al., 2013; Hatfield et al., 2016; Liakka et al., 2016). Fourth, the size and spatial distribution of land ice during past glacials determines crustal rebound processes when ice masses 
melt, which in turn affects sea-level reconstructions for subsequent interglacials. The latter are key to investigations of sea-level changes above the present level during warmer-than-present interglacials (e.g., the Last Interglacial, LIG, 130-118 kyr ago (ka); Hibbert et al., 2016; Hoffman et al., 2017; Hansen et al., 2017), which can reveal ice-sheet disintegration processes of relevance to the future (e.g., Dutton and Lambeck, 2012; Dutton et al., 2015a,b; Yamane et al., 2015; DeConto and Pollard, 2016).

Despite the relevance of these issues, we lack detailed information about ice volumes and their spatial extent during glacial maxima. Based on intervals of maximum global ice volume (lowest sea level), the Last Glacial Maximum (LGM) spanned the $26.5-19$ ka interval (Clark et al., 2009), while the Penultimate Glacial Maximum (PGM) spanned 155-140 ka, comprising two sea-level minima separated by a minor rise centred on 145 ka (Grant et al., 2014). In general, we know most about the LGM, and information decreases markedly for older glacial maxima. Even for the PGM, information is so limited that studies often invoke an LGM-like ice volume (e.g., Lambeck and Chappell, 2001; Yokoyama and Esat, 2011). Initial assessment of Red Sea glacial sea-level lowstands seemed to support that view (Rohling et al., 1998), but only constrained the LGM sea-level drop to have been at least as low as that of the PGM, without giving a maximum value. Here we show that subsequent improvements to the Red Sea record firmly indicate a greater sea-level drop during the LGM than during the PGM. Independent evidence from western Mediterranean palaeoshorelines also suggests that the LGM sea-level drop exceeded the PGM sea-level drop by about $10 \mathrm{~m}$ (Rabineau et al., 2006).

Robust quantitative assessment of sea-level differences between the last two glacial maxima is especially important because their spatial ice-mass distributions were markedly different (Table 1 summarises previously modelled ice-volume changes, relative to the present). Geological data and numerical modelling strongly suggest that the Eurasian ice sheet (EIS) covered a larger area during the PGM than during the LGM (Svendsen et al., 2004; Colleoni et al., 2011, 2016) (Fig. 1), with most estimates suggesting a PGM EIS volume equivalent to a 33-53 $\mathrm{m}$ global sea-level fall (sea-level equivalent, SLE) (Table 1); this is approximately twice the size of the LGM EIS (14-29 m $\mathrm{SLE}$; Table 1 and Clark and Tarasov, 2014). Such contrasting ice-mass distributions between successive glacial maxima highlight significant complexity in the processes that drive glaciation into different 'modes' (e.g., Liakka et al., 2016). The difference also has repercussions for glacioisostatic adjustment (GIA) studies of sea-level history during the LIG, which was about $1{ }^{\circ} \mathrm{C}$ warmer than the Holocene (Clark and Huybers, 2009; Turney and Jones, 2010; McKay et al., 2011; Hoffman et al., 2017; Hansen et al., 2017), with sea levels that reached 4-10 m higher than today (Rohling et al., 2008; Dutton and Lambeck, 2012; Grant et al., 2012; Stocker et al., 2013; Dutton et al., 2015a, 2015b). Dendy et al. (2017) investigated the sensitivity of the predictions of the last interglacial highstand to uncertainties in the configuration of the major northern hemisphere ice sheets during MIS 6. They focused on the sensitivity of the GIA correction to three major components of sea-level uncertainty during the MIS 6/5 transition: the age model and duration of deglaciation; the number of glacial cycles modelled during the GIA analysis; and the relative distribution of ice volume between the North American and Eurasian ice sheets, assuming that total ice volume for these complexes remained the same at MIS 2 and MIS 6. A key result is that sensitivity to different ice-sheet configurations is in the $\sim 5 \mathrm{~m}$ range (relative to the +4 to $+10 \mathrm{~m}$ observed for LIG sea level). This calls for exploration of further total ice-volume and ice-mass distribution scenarios for the MIS 6/5 transition.

Little evidence exists regarding the PGM North American Ice Sheet complex (NAIS), because the LGM advance obliterated virtually all PGM glaciomorphological evidence (we use EIS and NAIS to refer to all Eurasian and North American ice sheets, respectively, rather than separating all ice masses). For example, even when assuming an LGM-like ( $130 \mathrm{~m}_{\mathrm{SLE}}$, Clark et al., 2009) or smaller total PGM sea-level drop, with comparable Antarctic ice volume (Table 1) and a 33 to 53 or even $71 \mathrm{~m}_{\text {SLE }}$ EIS (Table 1), it follows that the NAIS must have been smaller than during the LGM. There is GIA modelling support for a smaller PGM NAIS to account for sea-level observations in Bermuda (Potter and Lambeck, 2003; Wainer et al., 2017), and climate modelling results agree best with global environmental proxy data in scenarios that combine a large EIS with a small NAIS ( $30 \mathrm{~m}_{\text {SLE }}$ ) (Colleoni et al., 2016). The lack of glaciomorphological evidence for the PGM NAIS also qualitatively supports a larger NAIS at the LGM than at the PGM.

Here we compile highly resolved data from multiple mutually independent sea-level reconstruction methods to gauge PGM sea level relative to the LGM. All have methodological and glacioisostatic uncertainties, and chronological uncertainties affect comparisons between records. But within individual records from the same method, high coherence is commonly achieved. Hence, confidence is higher for PGM-LGM comparisons within individual records than for relative sea-level comparisons among records. We use our PGM-LGM sea-level compilation in conjunction with a glaciogeomorphological synthesis of the PGM EIS and NAIS extent (Fig. 1, Appendix I; see acknowledgements for data access), as well as information from published ice-sheet modelling studies, to test the small-NAIS hypothesis. We then consider the implications of PGM-LGM differences in ice volume and extent, with respect to: 1) concepts of glacial inception; 2) glacioisostatic corrections to last interglacial sea levels; and 3) global sea-level/ice-volume $/ \delta^{18} \mathrm{O}$ relationships.

\section{PGM-LGM sea-level comparison}

We use five primary data sources to quantify PGM versus LGM ice volume/sea level (Fig. 2, Table 2). The first two are (near) continuous relative sea-level records derived from surface-water $\delta^{18} \mathrm{O}$ residence-time effects in the highly evaporative Red Sea and Mediterranean Sea (Siddall et al., 2003; Rohling et al., 2014). The third source is a (near) continuous time-series of past ice volume/ sea level from deep-sea seawater $\delta^{18} \mathrm{O}$, hereafter named $\delta_{\text {sw }}$ (e.g., Martin et al., 2002; Sosdian and Rosenthal, 2009; Elderfield et al., 2012). The fourth source for our assessment of a PGM-LGM sealevel offset concerns fossil coral position data $\left(Z_{\mathrm{cp}}\right)$ from a comprehensive database that has been harmonised in terms of dating and uplift-correction protocols (Hibbert et al., 2016). The fifth source consists of western Mediterranean palaeo-shorelines (Rabineau et al., 2006). The latter was discussed before, while the other four sources are detailed below.

\subsection{Red Sea and Mediterranean records}

The marginal-sea method for sea-level reconstruction relies on the fact that water residence time in the highly evaporative, semienclosed Red Sea and Mediterranean Sea is a function of sea-level change because of the narrow and shallow straits that connect the basins with the open ocean. In today's Red Sea, the Bab-elMandab Strait is only $137 \mathrm{~m}$ deep, mean annual evaporation is $\sim 2 \mathrm{~m} \mathrm{y}^{-1}$, and the basin has a narrow catchment with no major river systems or other hydrological complications (Siddall et al., 2004). For the Mediterranean, the Strait of Gibraltar is $284 \mathrm{~m}$ deep, mean annual evaporation is $\sim 1 \mathrm{~m} \mathrm{y}^{-1}$, and large river systems provide considerable hydrological complications. Thus, relative sea-level reconstructions have a higher signal-to-noise ratio at Bab-elMandab than at Gibraltar. Accordingly, $1 \sigma$ precision of individual 
Table 1

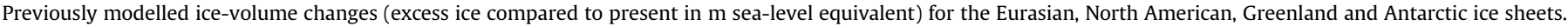

\begin{tabular}{|c|c|c|c|c|c|c|c|c|c|c|}
\hline \multirow[t]{2}{*}{ Study } & \multicolumn{2}{|l|}{ Eurasia } & \multicolumn{2}{|c|}{ North America } & \multicolumn{2}{|c|}{ Greenland } & \multicolumn{2}{|l|}{ Antarctica } & \multicolumn{2}{|l|}{ TOTAL } \\
\hline & LGM & PGM & LGM & PGM & LGM & PGM & LGM & PGM & LGM & PGM \\
\hline \multicolumn{11}{|l|}{ Colleoni et al., 2016 (PGM centred on $140 \mathrm{ka}$ ) } \\
\hline Topo1 & $n / r$ & $70^{\mathrm{a}, \mathrm{b}}$ & $n / r$ & $78^{\mathrm{a}, \mathrm{d}}$ & $n / r$ & $2^{\mathrm{c}}$ & $n / r$ & $17^{\mathrm{a}}$ & $n / r$ & $\sim 175^{\mathrm{b}}$ \\
\hline Topo2 & $n / r$ & $70^{\mathrm{a}, \mathrm{b}}$ & $n / r$ & $30^{\mathrm{a}, \mathrm{c}, \mathrm{d}}$ & $n / r$ & $2^{c}$ & $n / r$ & $17^{\mathrm{a}}$ & $n / r$ & $\sim 120^{\mathrm{b}}$ \\
\hline \multicolumn{11}{|l|}{ Wekerle et al., 2016 (PGM centred on $140 \mathrm{ka}$ ) } \\
\hline K140_Topo1 & $n / r$ & $71^{\mathrm{a}}$ & $n / r$ & $80^{\mathrm{c}, \mathrm{d}}$ & $n / r$ & $2^{\mathrm{c}}$ & $n / r$ & 17 & $n / r$ & 167 \\
\hline K140_Topo2 & $n / r$ & $71^{\mathrm{a}}$ & $n / r$ & $36^{\mathrm{c}, \mathrm{d}}$ & $n / r$ & $2^{\mathrm{c}}$ & $n / r$ & 17 & $n / r$ & 123 \\
\hline REF_Topo1 (GRISLI) & $n / r$ & 52 & $n / r$ & $84^{\mathrm{d}}$ & $n / r$ & $2^{\mathrm{c}}$ & $n / r$ & 17 & $n / r$ & 163 \\
\hline REF_Topo2 (GRISLI) & $n / r$ & 50 & $n / r$ & $59^{\mathrm{d}}$ & $n / r$ & $2^{c}$ & $n / r$ & 17 & $n / r$ & 149 \\
\hline Lambeck et al., 2006, 2010, $2017^{\text {g }}$ (PGM centred on $150 \mathrm{ka}$ ) & $18.25^{\mathrm{e}}$ & $52.5^{\mathrm{e}}$ & $85^{\mathrm{f}}$ & $68^{\mathrm{f}}$ & f & f & $n / r$ & $n / r$ & 130 & 130 \\
\hline de Boer et., $2014^{\mathrm{h}}$ (PGM centred on $144 \mathrm{ka}$ ) & 33.5 & 33.2 & 49.8 & 58.3 & 0.9 & 2.7 & 12.6 & 12.6 & 98.0 & 107.7 \\
\hline \multicolumn{11}{|l|}{ this study (PGM centred on $152 \mathrm{ka}$ ) } \\
\hline ICE-1 & $23^{c}$ & $23^{c}$ & $85.2^{c}$ & $85.2^{\mathrm{c}}$ & $2^{c}$ & $2^{\mathrm{c}}$ & $18.1^{\mathrm{c}}$ & $18.1^{\mathrm{c}}$ & 129.5 & 129.5 \\
\hline ICE-2 & $23^{c}$ & 20.7 & $85.2^{c}$ & 76.7 & $2^{c}$ & 1.1 & $18.1^{\mathrm{c}}$ & $10.2^{\mathrm{c}}$ & 129.5 & 109.5 \\
\hline ICE-3 & $23^{c}$ & 60 & $85.2^{c}$ & 32 & $2^{c}$ & 1.1 & $18.1^{\mathrm{c}}$ & $15.8^{\mathrm{c}}$ & 129.5 & 109.5 \\
\hline ICE-4 & $23^{c}$ & 60 & $85.2^{\mathrm{c}}$ & 32 & $2^{c}$ & 1.1 & $18.1^{\mathrm{c}}$ & $15.8^{\mathrm{c}}$ & 129.5 & 109.5 \\
\hline CMIP5/PMIP3 composite (Abe-Ouchi et al., 2015) & 16.6 & $n / r$ & 78.6 & $n / r$ & & $n / r$ & 22.3 & $n / r$ & 121.5 & $n / r$ \\
\hline ICE-4G (Peltier, 1994, 1996) (LGM at $21 \mathrm{ka})^{\mathrm{i}}$ & $24.86^{\mathrm{j}}$ & $n / r$ & 64.24 & $n / r$ & $6.38^{\mathrm{k}}$ & $n / r$ & 18.09 & $n / r$ & 114.12 & $n / r$ \\
\hline ICE-5G v.1.2 (Peltier, 2004) (LGM at $26 \mathrm{ka})^{\mathrm{i}}$ & $22.73^{j}$ & $n / r$ & 83.71 & $n / r$ & $2.45^{\mathrm{k}}$ & $n / r$ & 18.04 & $n / r$ & 127.48 & $n / r$ \\
\hline ICE-6G v.2 (Argus et al., 2014; Peltier et al., 2015) (LGM at $26 \mathrm{ka})^{\mathrm{i}}$ & $22.23^{j}$ & $n / r$ & 88.14 & $n / r$ & $2.34^{\mathrm{k}}$ & $n / r$ & 13.23 & $n / r$ & 126.81 & $n / r$ \\
\hline Siegert et al., 2001 (LGM at $\sim 20 \mathrm{ka}$ ) & 14 & $n / r$ & $n / r$ & $n / r$ & $n / r$ & $n / r$ & $n / r$ & $n / r$ & $n / r$ & $n / r$ \\
\hline van den Berg et al., 2008 (LGM at $\sim 25 \mathrm{ka}$ ) & $\sim 22$ & $n / r$ & $n / r$ & $n / r$ & $n / r$ & $n / r$ & $n / r$ & $n / r$ & $n / r$ & $n / r$ \\
\hline Patton et al., 2016 (LGM at $\sim 22 \mathrm{ka}$ ) & 17 & $n / r$ & $n / r$ & $n / r$ & $n / r$ & $n / r$ & $n / r$ & $n / r$ & $n / r$ & $n / r$ \\
\hline Marshall et al., 2002 & $n / r$ & $n / r$ & 69 to 94 & $n / r$ & $n / r$ & $n / r$ & $n / r$ & $n / r$ & $n / r$ & $n / r$ \\
\hline Tarasov et al., 2012 (LGM at $\sim 20 \mathrm{ka}$ ) & $n / r$ & $n / r$ & $70.1 \pm 2$ & $n / r$ & $n / r$ & $n / r$ & $n / r$ & $n / r$ & $n / r$ & $n / r$ \\
\hline Denton and Hughes, 2002 & $n / r$ & $n / r$ & $n / r$ & $n / r$ & $n / r$ & $n / r$ & 14 & $n / r$ & $n / r$ & $n / r$ \\
\hline Ivins and James, 2005 (LGM at $21 \mathrm{ka}$ ) & $n / r$ & $n / r$ & $n / r$ & $n / r$ & $n / r$ & $n / r$ & 10.12 & $n / r$ & $n / r$ & $n / r$ \\
\hline Whitehouse et al., 2012 (LGM at 20 ka) & $n / r$ & $n / r$ & $n / r$ & $n / r$ & $n / r$ & $n / r$ & $9 \pm 1.5$ & $n / r$ & $n / r$ & $n / r$ \\
\hline Briggs et al., 2014. (LGM at $24 \mathrm{ka}$ ) & $n / r$ & $n / r$ & $n / r$ & $n / r$ & $n / r$ & $n / r$ & $\begin{array}{l}5.6 \text { to } \\
14.3\end{array}$ & $n / r$ & $n / r$ & $n / r$ \\
\hline Argus et al., 2014. (ICE-6G) & $n / r$ & $n / r$ & $n / r$ & $n / r$ & $n / r$ & $n / r$ & 13.6 & $n / r$ & $n / r$ & $n / r$ \\
\hline Huybrechts, 2002 (LGM at $\sim 21 \mathrm{ka}$ ) & $n / r$ & $n / r$ & $n / r$ & $n / r$ & 2 to 3 & $n / r$ & 14 to 18 & $n / r$ & $n / r$ & $n / r$ \\
\hline Huy2 (Simpson et al., 2009) & $n / r$ & $n / r$ & $n / r$ & $n / r$ & 4.1 & $n / r$ & $n / r$ & $n / r$ & $n / r$ & $n / r$ \\
\hline Huy3 (Lecavalier et al., 2014) & $n / r$ & $n / r$ & $n / r$ & $n / r$ & $>4.7$ & $n / r$ & $n / r$ & $n / r$ & $n / r$ & $n / r$ \\
\hline $\begin{array}{l}\text { Range (excepting ICE- } 1 \text { to ICE- } 4 \text { values and any initial, offline boundary } \\
\text { estimates) }\end{array}$ & $\begin{array}{l}14 \text { to } \\
29\end{array}$ & $\begin{array}{l}33.2 \text { to } \\
52.5\end{array}$ & $\begin{array}{l}50.6 \text { to } \\
94\end{array}$ & $\begin{array}{l}32 \text { to } \\
84\end{array}$ & $\begin{array}{l}2 \text { to } \\
\sim 6\end{array}$ & 2 & 9 to 22.3 & $\begin{array}{l}10.2 \text { to } \\
17\end{array}$ & $\begin{array}{l}98 \text { to } \\
130\end{array}$ & $\begin{array}{l}107 \text { to } \\
163\end{array}$ \\
\hline
\end{tabular}

$n / r$ Not reconstructed.

a Initial volumes used as boundary conditions for offline GCM climate modelling, rather than modelled ice-volume estimates per se.

b Peyaud (2006), based on the Lambeck et al. (2006) PGM model estimate of $140 \mathrm{~m}_{\mathrm{SLE}}$ total ice volume, of which the EIS constitutes $50 \%$.

c Values based on LGM ICE-5G files made available by R. Peltier at atnwww.atmosp.physics.utoronto.ca/ peltier/data.php, which differ slightly from the published ICE-5G reconstruction of Peltier (2004).

d Laurentide only.

e Eurasian $=$ Fennoscandian in this reconstruction.

f North American estimates include Greenland Ice Sheet.

$g$ Values used in the most recent iteration of the ANU model (values from A. Purcell, pers. comm.).

h Values used were obtained from ice files provided by de Boer (pers. comm., and now available in slightly different format on http://www.staff.science.uu.nl/ boer0160/ data.php), re-gridded and assuming ice/water density constants of $1000 / 920 \mathrm{~kg} / \mathrm{m}^{3}$, to translate values to $\mathrm{m}_{\mathrm{SLE}}$.

i Values based on ICE-5G version 1.2. of R. Drummond, available at https://wiki.lsce.ipsl.fr/pmip3/doku.php/pmip3:design:21k:icesheet:index.

j Eurasian = Fennoscandian, Barents/Kara Seas, and British-Irish Ice Sheets.

k These values, provided by R. Drummond (see note $i$ ), are combined volumes for the Greenland and Iceland Ice Sheets, although each ice sheet is modelled separately in ICE$4 \mathrm{G},-5 \mathrm{G},-6 \mathrm{G}$.

Red Sea values from this method is about $\pm 6 \mathrm{~m}$ (Siddall et al., 2003 2004), compared with $\pm 9 \mathrm{~m}$ to $\pm 14 \mathrm{~m}$ for individual Mediterranean values at interglacial to glacial conditions, respectively (Rohling et al., 2014). Near-continuous records can be evaluated probabilistically, accounting for both age uncertainties and sea-level uncertainties. These assessments identify probability maxima and their 95\% probability bounds (Grant et al., 2012, 2014; Rohling et al., 2014), which we use here. The two basins are independent; they are not connected, and link with separate oceans with different climate and ocean circulation dynamics (Schott et al., 2009; Buckley and Marshall, 2016).

A data-gap exists in the Red Sea LGM record due to an indurated 

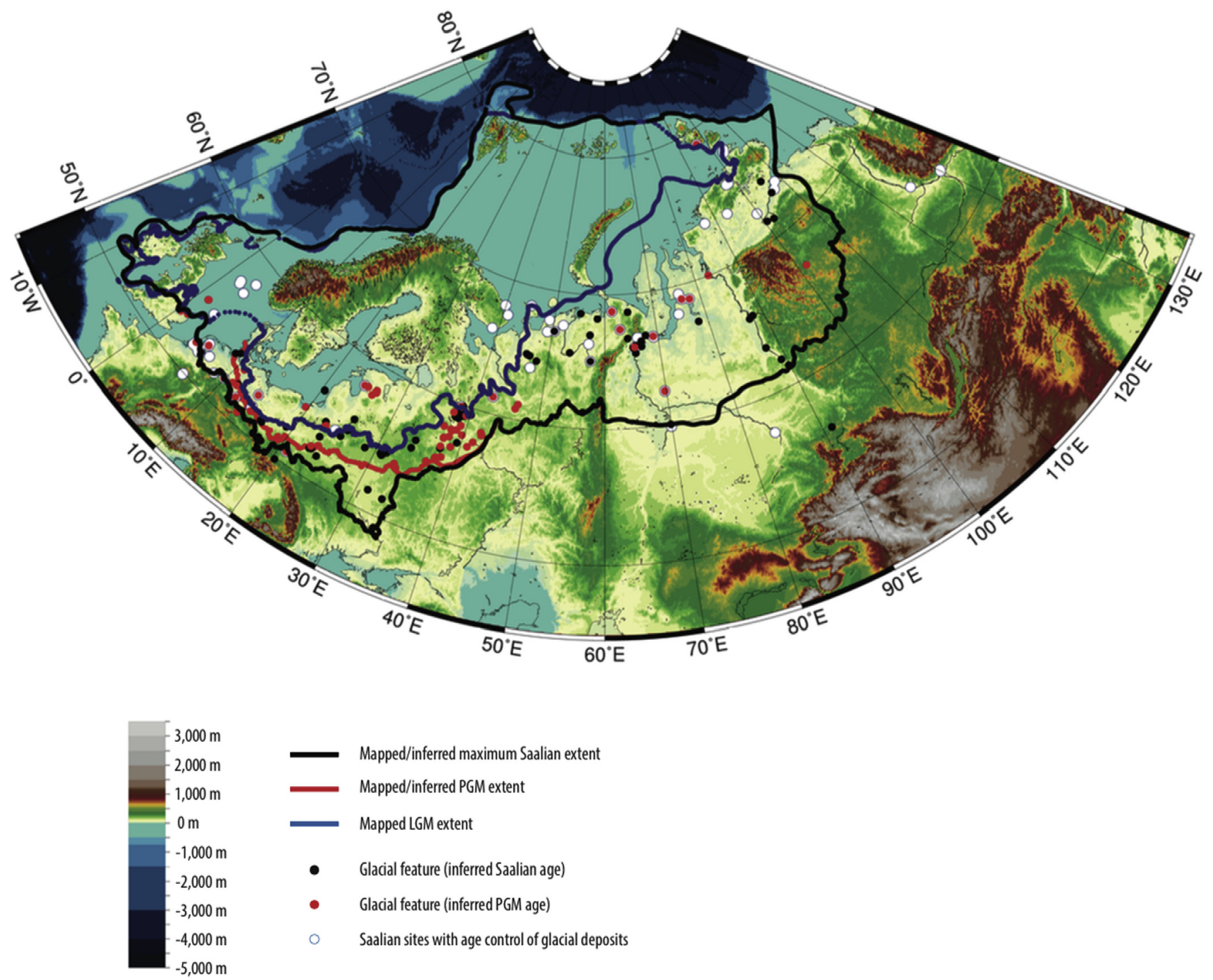

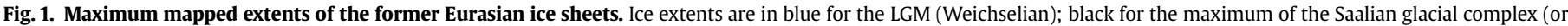

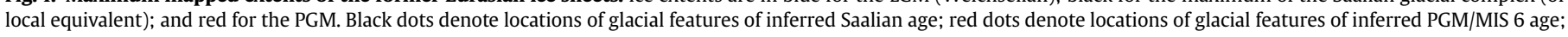

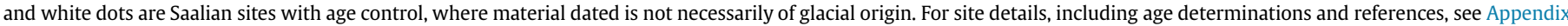

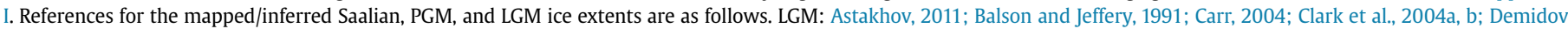

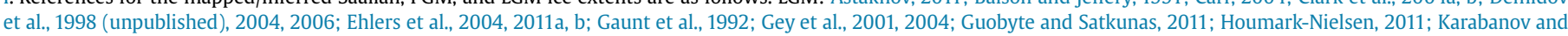

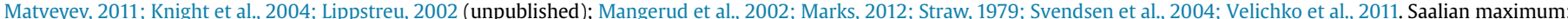

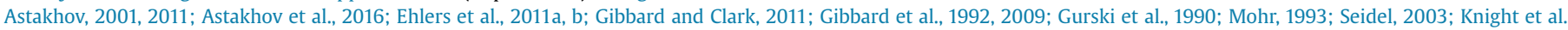

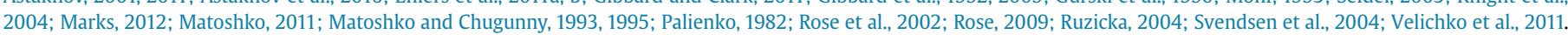

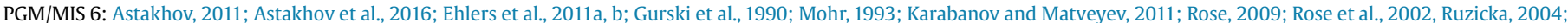
Velichko et al., 2011.

layer without planktonic foraminifera (e.g., Fenton et al., 2000 and references therein); only a few sea-level values could be recovered from this "aplanktonic" layer (Fig. 2b). However, sparse LGM data from bulk carbonate are supported by other Red Sea records that indicate a $5-5.5 \%$ change in foraminiferal $\delta^{18} \mathrm{O}$ between the LGM and present (Arz et al., 2003, 2007), compared with 4\% between the PGM and present (Rohling et al., 2009). Moreover, the aplanktonic LGM Red Sea conditions offer strong independent evidence that LGM sea level was lower than in the PGM. It formed under extreme salinities ( $\mathrm{S}=\sim 50$ to $\sim 70$ ) due to near-isolation of the Red Sea from the world ocean by the shallow Hanish Sill, Bab-elMandab Strait ( $137 \mathrm{~m}$ deep, relative to an LGM global mean sealevel drop of $\sim 130 \mathrm{~m}$ ); such extreme conditions were not reached during the PGM (Rohling et al., 1998; Fenton et al., 2000; Siddall et al., 2003). This implies either that: (a) the sill was uplifted between the PGM and LGM; and/or (b) sea level dropped more during the LGM than the PGM. Sill uplift has been quantified at $0.02-0.04 \mathrm{~m} \mathrm{kyr}^{-1}$, which gives at most $5 \mathrm{~m}$ of uplift from PGM to LGM (Rohling et al., 1998; Siddall et al., 2003). This is insufficient to explain the large LGM-to-PGM environmental contrast, so we conclude that sea level dropped much more during the LGM than in the PGM.

Our new Mediterranean $\delta^{18} \mathrm{O}$ stack-based RSL record (Fig. 2a and Fig. 3) includes $\delta^{18} \mathrm{O}$ data from four cores: LC21 ( $35^{\circ} 40^{\prime} \mathrm{N}, 26^{\circ} 35^{\prime} \mathrm{E}$, $1522 \mathrm{~m}$ water depth) (Grant et al., 2012); MS21 $\left(32^{\circ} 20.7^{\prime} \mathrm{N}\right.$, 31 39.0'E, $1022 \mathrm{~m}$ water depth) (Hennekam, 2015); M40-67 $\left(34.814167^{\circ} \mathrm{N}, 27.296000^{\circ} \mathrm{E}\right.$, water depth $\left.2157 \mathrm{~m}\right)$, and $\mathrm{M} 40-71$ $\left(34.811160^{\circ} \mathrm{N}, 23.194160^{\circ} \mathrm{E}\right.$, water depth $2788 \mathrm{~m}$ ) (Weldeab et al., 

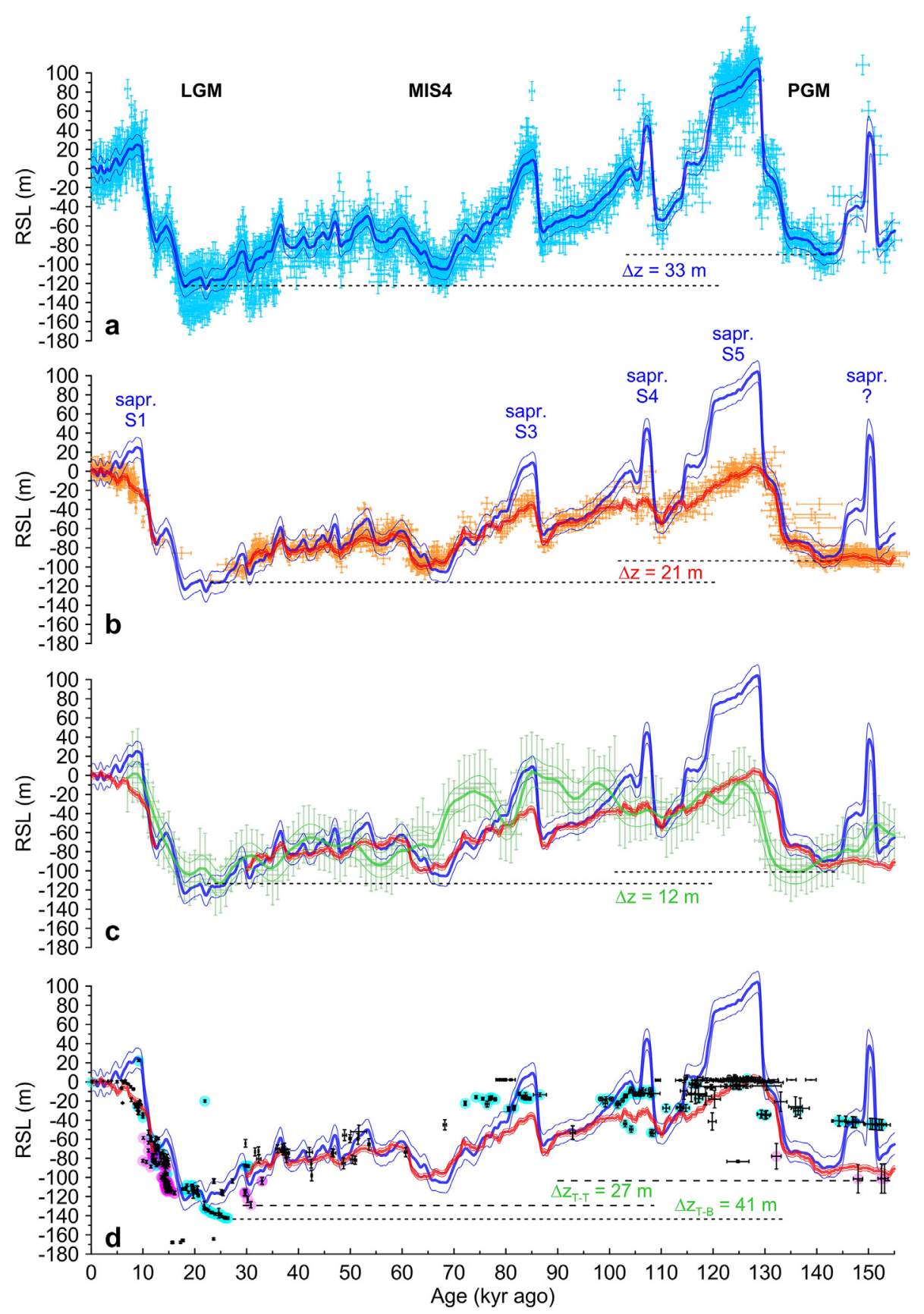

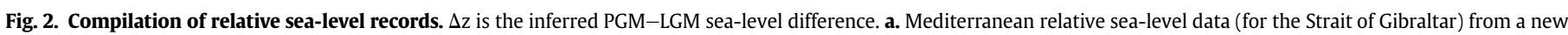

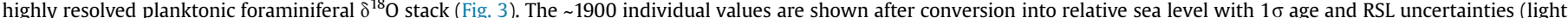

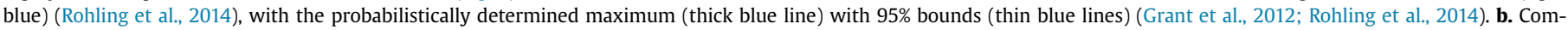

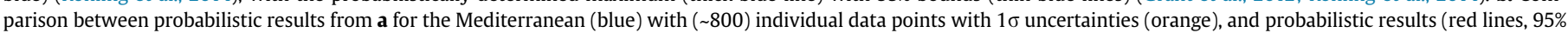

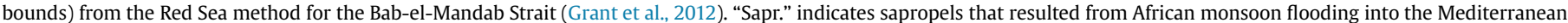

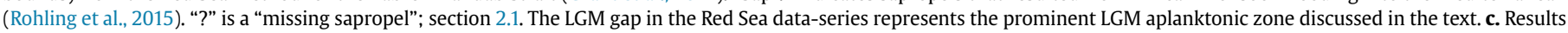

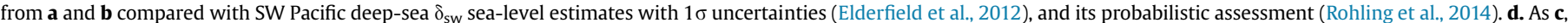

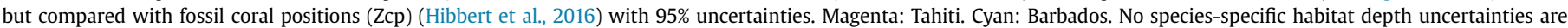

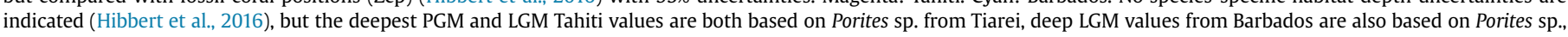
but possess wider depth ranges. Hence, we focus on the PGM Tahiti-LGM ${ }_{\text {Tahiti }}$ comparison (Table 2).

2003a,b). $\delta^{18} \mathrm{O}$ records include data for the surface-dwelling planktonic foraminifer Globigerinoides ruber (white) for all cores, and for the subsurface-dwelling planktonic foraminifer Neogloboquadrina pachyderma (dextral) for core LC21 (habitats after Rohling et al., 2004), and we use conversions to sea level after Rohling et al. (2014). The age model for each core is based on tuning to the Soreq Cave (Israel) speleothem $\delta^{18} \mathrm{O}$ record (Bar-Matthews et al., 2003; Grant et al., 2012; Hennekam, 2015), and recalibrating original ${ }^{14} \mathrm{C}$ datings with the most recent ${ }^{14} \mathrm{C}$ calibration curve (Reimer et al., 2013) using a $\Delta \mathrm{R}$ value of $35 \pm 70$ years (Siani et al., 2000).

In the Mediterranean, the marginal-basin method has limitations at times of strong northern hemisphere insolation maxima, when African monsoon intensification led to large-scale freshwater 
Table 2

Results of PGM-LGM sea-level comparisons.

\begin{tabular}{|c|c|c|c|c|c|c|c|c|}
\hline & $\begin{array}{l}\text { Mean } \\
\mathbf{z}_{\mathrm{LGM}} \\
\end{array}$ & $95 \%$ bounds & $\begin{array}{l}\text { Mean } \\
\mathbf{z}_{\mathrm{PGM}} \\
\end{array}$ & $95 \%$ bounds & $\Delta \mathrm{z}$ & $\begin{array}{l}95 \% \text { bounds } \\
\text { to } \Delta z\end{array}$ & df & Probability that means are equal \\
\hline Mediterranean Sea & -124 & 11 & -90 & 11 & 34 & 15 & 3998 & $P \ll 0.0001$ \\
\hline Red Sea & $(-116)$ & 6 & -96 & 3 & 20 & 7 & 999 & $P \ll 0.0001$ \\
\hline Elderfield et al. (2012) & -113 & 13 & -101 & 13 & 12 & 18 & 1998 & $\mathrm{P}=0.09$ \\
\hline Corals (Tahiti only) & -129 & 3 & $(-101)$ & 15 & 28 & 15 & 3 & $\mathrm{P}=0.02$ \\
\hline Corals $\left(\mathrm{PGM}_{\text {Tahiti }}-\mathrm{LGM}_{\text {Barbados }}\right)$ & -142 & 1 & $(-101)$ & 15 & 41 & 15 & 8 & $P=0.0003$ \\
\hline Rabineau et al. (2006)* & -102 & 6 & -92 & 7 & 10 & 9 & $\mathrm{n} / \mathrm{a}$ & $\mathrm{n} / \mathrm{a}$ \\
\hline
\end{tabular}

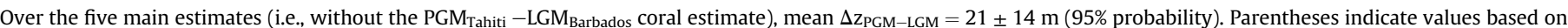

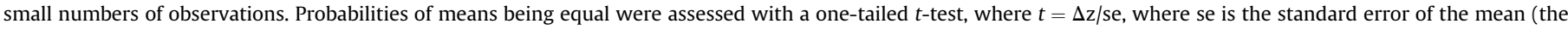

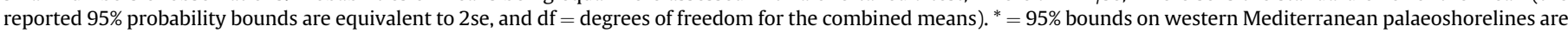

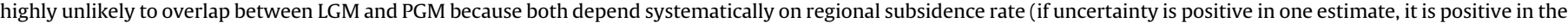
other); hence, the $t$-test is not applicable, as it assumes random-normal distributions instead of systematically related uncertainties.

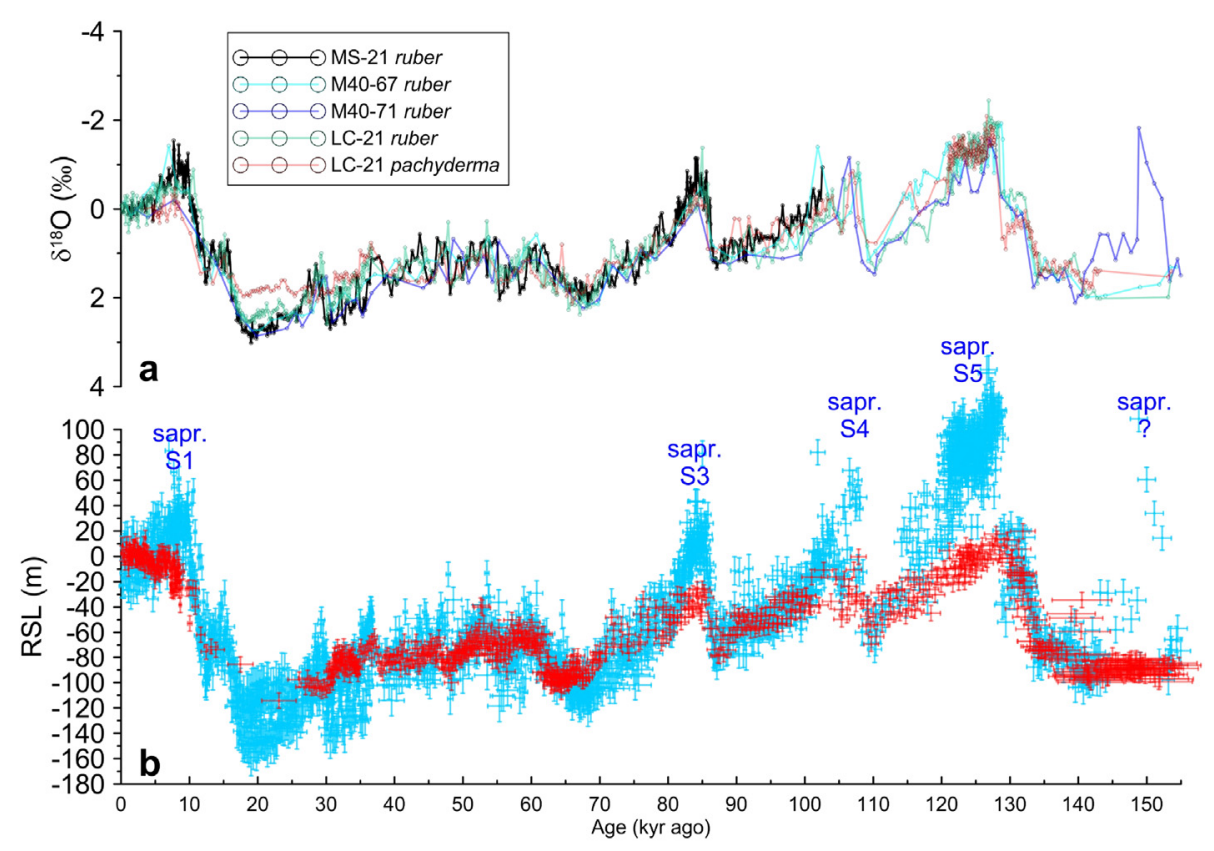

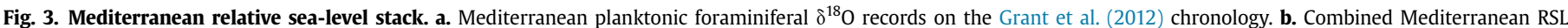

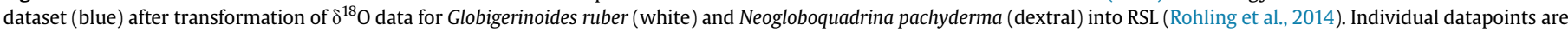

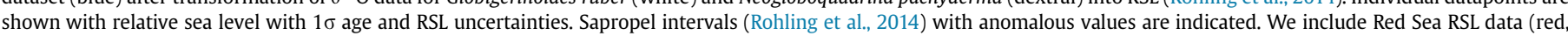

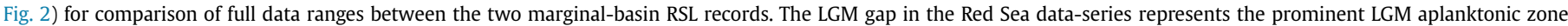
discussed in the text.

flooding into the basin from the Nile and other (now dry) North African river systems (e.g., Rohling et al., 2002, 2004, 2014, 2015; Larrasoaña et al., 2003; Scrivner et al., 2004; Osborne et al., 2008; Hennekam, 2015). Such times are identified in Mediterranean sediment cores based on sharply delineated intervals of low surface-water oxygen isotope $\left(\delta^{18} \mathrm{O}\right)$ anomalies (Fig. 3), increased sediment organic-matter accumulation under low-oxygen to anoxic deep-water conditions, and sediment barium enrichments (for a review, see Rohling et al., 2015). These organic-rich intervals are known as sapropels. Some sapropels have been oxidised after deposition (ghost sapropels), or organic carbon burial remained limited due to continued deep-water ventilation (missing sapropels), but in those cases the intervals can still be identified using other characteristic signals (Rohling et al., 2014). Hence, sapropel intervals are easily identified, and they do not affect our Mediterranean-based RSL values for the LGM or PGM (Figs. 2 and 3).

For both the Red Sea and Mediterranean records, individual data values (with uncertainties in both age and sea-level value) are not instructive for determining the PGM-LGM difference. Instead the overall structure of the records needs to be used, which accounts for covariations and autocorrelations within the record (systematic elements in the uncertainties). For this, we use Monte-Carlo-style probabilistic evaluations of the highly resolved data series that determine the probability maximum (modal value) and its 95\% probability interval. Here we use published results for the Red Sea (Grant et al., 2012) and new results from the same method for our new Mediterranean stack (Fig. 2a and b). Good signal agreement exists between the Mediterranean and Red Sea records, except during the sharply delineated Mediterranean sapropel intervals. In those intervals, freshwater-induced low $-\delta^{18} \mathrm{O}$ surface-water conditions (e.g., Rohling et al., 2002, 2004) yield spurious (high) sealevel extremes in the Mediterranean reconstruction (Fig. $2 \mathrm{~b}$ and Fig. 3), which can be discarded when identified using associated sapropel indicators (Rohling et al., 2014, 2015).

\subsection{Deep-sea seawater $\delta^{18} \mathrm{O}$}

Highly resolved time-series of past sea-level variability can also be obtained from $\delta_{\text {sw }}$ data (e.g., Sosdian and Rosenthal, 2009; 
Martin et al., 2002; Elderfield et al., 2012). These are derived from benthic foraminiferal carbonate $\delta^{18} \mathrm{O}$ data $\left(\delta_{\mathrm{c}}\right)$ that are corrected for temperature changes using $\mathrm{Mg} / \mathrm{Ca}$ analyses of the same benthic foraminifera (Martin et al., 2002; Sosdian and Rosenthal, 2009; Elderfield et al., 2010, 2012). Variations in $\delta_{\text {sw }}$ primarily represent global ice-volume changes that are related to global sea-level changes via isotope mass-balance calculations. But deep-sea temperature changes are relatively small $\left(\sim 3{ }^{\circ} \mathrm{C}\right.$ between glacials and interglacials), and the $\mathrm{Mg} / \mathrm{Ca}$ method cannot resolve them to better than about $\pm 1{ }^{\circ} \mathrm{C}(1 \sigma)$. Note that the deep-sea $\delta_{\text {sw }}$ method also involves assumptions about the ice- $\delta^{18} \mathrm{O}$ value when converting $\delta_{\text {sw }}$ into ice-volume estimates (this is further discussed on the basis of results from this study, in section 4.3). Overall, the deep-sea $\delta_{\text {sw }}$ method yields individual sea-level estimates with uncertainties of about $\pm 30 \mathrm{~m}$. Again, probabilistic assessment of highly resolved, coherent $\delta_{\text {sw }}$ records from single cores with strictly constrained stratigraphy allows recovery of the overall structure of changes with narrower uncertainties. Therefore, we use the results from a probabilistic assessment of a single coherent $\delta_{\text {sw }}$ record of SW Pacific abyssal waters that likely presents a well-integrated global signal (Elderfield et al., 2012). Specifically, we use a probabilistic assessment of that record, which highlights the overall signal structure, and accounts for both chronological and sea-level uncertainties (Rohling et al., 2014) (Fig. 2c).

\subsection{Fossil coral data}

Fossil corals provide valuable insights into past changes in sea level. However, they are discrete rather than continuous estimates and are associated with several locational (tectonic and glacioisostatic) as well as biological (e.g., palaeo-water depth) assumptions. For coral-based evidence of past sea levels, we extract fossil coral position data $\left(Z_{\mathrm{cp}}\right)$ from the methodologically harmonised database of Hibbert et al. (2016), with $2 \sigma$ uncertainties (Fig. 2d). We consider only samples that pass the following screening criteria: (a) $\%$ calcite $<2$; (b) ${ }^{232} \mathrm{Th}$ concentration < $2 \mathrm{ppb}$; and $(c)$ $\delta^{234} U_{\text {initial }}=147 \pm 5 \%$ (ages $<17 \mathrm{ka}$ and 71 to $130 \mathrm{ka}$ ), $\delta^{234} U_{\text {initial }}=142 \pm 8 \%$ (ages 17 to $71 \mathrm{ka}$ ), and $\delta^{234} U_{\text {initial }}=147$ $+5 /{ }_{-10} \%$ o (ages $>130 \mathrm{ka}$ ).

It is difficult to use fossil corals to determine sea-level lowstands of glacial maxima before the LGM because the evidence is hidden at poorly accessible water depths, buried under younger sediments, or overgrown by corals from subsequent lowstands. Consequently, no site currently has both LGM and PGM coral sea-level estimates. Drill cores from Tahiti, however, have corals from the PGM (Thomas et al., 2009) as well as corals 'bracketing' the LGM (Bard et al., 1996, 2010; Thomas et al., 2009; Deschamps et al., 2012). Tahiti is also unusual in that it has independently constrained subsidence rates (based on radiometrically dated lava flows; Bard et al., 1996; Le Roy, 1994), which - when assumed to be constant through time - help in obtaining good tectonically corrected elevations. A drill core from Tiarei (Tahiti; Thomas et al., 2009) has in-growthposition corals of the same genus (Porites sp.) for the PGM and the end of Marine Isotope Stage 3 (end of MIS 3; 29 ka). While taxonomically similar, these corals are from different assemblages and have been assigned different palaeo-waterdepth estimates, with the MIS 3 samples likely representing a deeper, fore-reef setting (Montaggioni, 2005). The same site (Tiarei) also has a taxonomically different in-growth-position coral at a similar tectonically corrected elevation as the MIS 3 corals, dated to $16 \mathrm{ka}$ (Pocillopora sp., Deschamps et al., 2012). Taken together, the corals dated at $\sim 29$ ka and 16 ka provide a minimum estimate of the LGM sea-level drop, given that LGM sea level likely fell below the elevation of these 'bracketing' corals. Based on this minimum LGM sea-level-drop estimate, we infer a coral-based minimum estimate for the PGM-LGM sea-level difference of $\sim 14 \mathrm{~m}$. If the mean $Z_{\mathrm{cp}}$ values for the end-of-MIS 3 and PGM corals are taken at face value (taking the end-of-MIS 3 as indicative of the LGM), then the inferred PGM-LGM sea-level difference is $\sim 27 \mathrm{~m}$ (Fig. 2d). Note that comparison with Barbados LGM data (also Porites; Bard et al., 1990; Fairbanks et al., 2005) suggests a potentially greater PGM-LGM offset $(\sim 41 \mathrm{~m})$, but this estimate is subject to differences between the geological and glacioisostatic settings of Barbados and Tahiti. We therefore concentrate on the 'face-value' estimate from Tahiti as the most representative coral-based estimate (Fig. 2d, Table 2).

We do not suggest that the data in Fig. $2 d$ represent a finished coral-based sea-level record because that would require - most importantly - additional high-quality coral data for both the LGM and PGM, and additional study-specific considerations that include stratigraphic and biological assemblage arguments, and glacioisostatic corrections among sites (for discussion, see Hibbert et al. (2016) and references therein). Given the current limited availability of (screened) data, such a complete assessment is not yet feasible. Instead, we merely use the data to show amplitude agreement between coral data and other reconstructions, and then focus on the PGM-LGM difference.

\subsection{Synthesis of PGM-LGM sea-level contrasts}

The depth difference $(\Delta z)$ between PGM and LGM sea-level estimates is highlighted in Fig. 2 for each method considered, and considered alongside the western Mediterranean palaeo-shoreline evidence of Rabineau et al. (2006) (see also Table 2). We find that all five methods (six with two coral options) reveal a coherent PGM-LGM sea-level offset with mean $\Delta z=21 \pm 14 \mathrm{~m}$ (95\% probability). In IPCC terminology (Stocker et al., 2013), therefore, it is virtually certain for the PGM-LGM that $\Delta z$ exceeds $0 \mathrm{~m}$, and extremely likely that $\Delta z$ falls between 7 and $35 \mathrm{~m}$. The fact that the five methods are independent of each other is strong validation of our $\Delta \mathrm{z}$ observations. Furthermore, a lower LGM global sea level (hence a larger global ice volume), relative to the PGM, agrees qualitatively with glacial-cycle model results driven by astronomical cycles and greenhouse gas $\left(\mathrm{CO}_{2}\right)$ fluctuations $(\Delta \mathrm{z}=\sim 10 \mathrm{~m})$ (Abe-Ouchi et al., 2013), and with the aforementioned Red Sea aplanktonic-zone observations.

To test the sensitivity of our approach for detecting sea-level differences, we also compare sea levels for the PGM with those

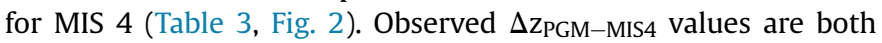
positive and negative. Even if the anomalous value with negative $\Delta$ z $_{\text {PGM-MIS4 }}$ is omitted, the $95 \%$ probability bounds for mean $\Delta z_{\text {PGM-MIS4 }}$ still overlap with zero. At $95 \%$ probability, therefore, PGM and MIS 4 sea levels cannot be distinguished, whereas PGM and LGM sea level were clearly different.

\section{PGM-LGM contrasts in ice extent and volume}

\subsection{Synthesis of PGM ice-sheet extents, mapping and dating}

Extensive mapping of glacial features (moraines, till and glacial outwash sequences, etc.) suggests that the southern limit of the EIS extended much further to the south during the Saalian maximum, relative to the LGM (see compilation of Svendsen et al. (2004), updated in Ehlers et al. (2011a) and references therein). The Saalian complex of glaciogenic landforms and sediments includes multiple glacial episodes between the Holsteinian and Eemian interglacials (Gibbard and Cohen, 2008), including the PGM. The maximum extent of each of these glaciations was not necessarily reached at the same time along the entirety of the ice margin; effectively they were spatially variable and diachronous glacial maxima. The PGM limits are well-documented only for the SW margins of the EIS (e.g., 
Table 3

Results of PGM-MIS4 sea-level comparisons.

\begin{tabular}{|c|c|c|c|c|c|c|c|c|}
\hline & $\begin{array}{l}\text { Mean } \\
\mathbf{z}_{\text {MIS4 }}\end{array}$ & $95 \%$ bounds & $\begin{array}{l}\text { Mean } \\
\mathbf{z}_{\mathrm{PGM}}\end{array}$ & $95 \%$ bounds & $\Delta \mathrm{z}$ & $\begin{array}{l}95 \% \text { bounds } \\
\text { ( } 2 \text { se equi-valent) }\end{array}$ & df & Probability that means are equal \\
\hline Mediterranean Sea & -105 & 11 & -90 & 11 & 15 & 15 & 3998 & $P=0.02$ \\
\hline Red Sea & -100 & 3 & -96 & 3 & 4 & 5 & 1998 & $P=0.06$ \\
\hline Elderfield et al. (2012) & -93 & 13 & -101 & 13 & -8 & 18 & 1998 & $P=0.19$ \\
\hline
\end{tabular}

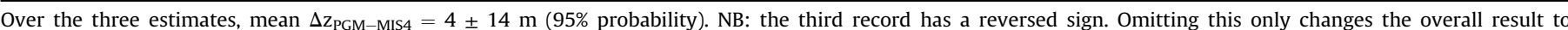
$\Delta \mathrm{z}_{\mathrm{PGM}-\mathrm{MIS} 4}=10 \pm 11 \mathrm{~m}$ (95\% probability). Probabilities of means being equal were assessed as in Table 2.

Netherlands, Busschers et al., 2005, 2008; Laban and van der Meer, 2004, 2011 and references therein; Germany, Ehlers et al., 2011b; Litt et al., 2007; Poland, Marks, 2011 and references therein). Reconstructions for the eastern sector are more tentative (e.g., Astakhov, 2011, 2013; Velichko et al., 2011; Möller et al., 2015; Astakhov et al., 2016), and much of the literature is restricted to Russian sources (for reviews, see Astakhov, 2013; Astakhov et al., 2016).

The record of the PGM glaciation in North America is more fragmentary than that for Eurasia. In general, the Laurentide LGM ice limits are the most extensive (e.g., Dyke et al., 2002), except for some protrusions of older glacial material, e.g., in Illinois (type section for the pre-LGM Illinoian glaciation that includes the PGM, Curry et al., 2011), where several glacial till members and glacial ridges extend beyond the Wisconsinan (LGM) limits, with OSL constraints that suggest three advances within MIS 6 (McKay and Berg, 2008; McKay et al., 2008; Webb et al., 2012). More extensive pre-LGM (including Illinoian) ice limits have also been reported in Ohio (e.g., Pavey et al., 1999; Szabo and Totten, 1995; Szabo et al., 2011; Fugitt et al., 2016), Pennsylvania (Braun, 2011 and references therein), Missouri (e.g., Rovey and Balco, 2011), and Wisconsin (Syverson and Colgan, 2011), but age control and correlations are problematic. For the Cordilleran Ice Sheet (contributing to our broad NAIS interpretation), continental-ice presence is documented in NW Canada and Alaska only for the Late Pleistocene (i.e., post-PGM). The sedimentary record captures a succession of plateau/montane glaciations (often successively less extensive than the previous), but only a single continental glaciation (Liverman et al., 1989; Jackson et al., 1991; Young et al., 1994; Duk-Rodkin et al., 1996; Harris, 2005; Barendregt and DukRodkin, 2011; Clague and Ward, 2011; Jackson et al., 2011; Demuro et al., 2012; Turner et al., 2013). Uncertain, and often inconsistent age control again hinders correlation of these pre-LGM glaciations (e.g., Stroeven et al., 2010, 2014).

Marine records offer a (potentially) continuous record of PGM ice-sheet dynamics. The input of ice-rafted debris (IRD) allows reconstruction of ice sheet dynamics, ice source, and iceberg-melt location (Ruddiman, 1977; Bond and Lotti, 1995; Hemming, 2004). The marine record of Eurasian glacial episodes (e.g., Spielhagen et al., 2004; Sejrup et al., 2005; Toucanne et al., 2009; Obrochta et al., 2014; Löwemark et al., 2016) and geophysical mapping (e.g., Polyak et al., 2001, 2004; Jakobsson et al., 2010; Niessen et al., 2013; Dove et al., 2014), indicate differences between the LGM and PGM glaciations, with suggestions that the PGM/MIS 6 glaciation was one of the more extensive glacial episodes. Conversely, IRD from North America (Hudson Strait) does not seem to have reached the North Atlantic IRD belt during the penultimate glacial cycle (Obrochta et al., 2014), while it still occurred in the Labrador Sea, in close proximity to the eastern North American margin (Channell et al., 2012). This contrasts with large quantities of North American IRD in the IRD belt during the last glacial cycle (e.g., Ruddiman, 1977; Hemming, 2004), which suggests likely differences in ice-mass distribution and ice-stream dynamics between the PGM and LGM NAIS.
Robust correlations and chronology of mapped pre-LGM ice advances have proven elusive, not least due to difficulties in continental-scale correlation of glacial features/stratigraphic units and the proliferation of stratigraphic terminology. These difficulties are compounded when comparing terrestrial records of glaciation with marine records (e.g., Mix et al., 2001). For example, the last glacial interval in the marine record, MIS2 (Imbrie et al., 1984; Martinson et al., 1987; Lisiecki and Raymo, 2005), represents an interval of maximum global ice volume, which does not necessarily correspond to the timing of maximum mapped glacial extents on land, which are themselves globally asynchronous (e.g., Ehlers and Gibbard, 2007). Correlations between glacial units, and correlations to the marine record are also affected by methodological constraints of the various absolute dating methods. The PGM falls outside the range of the radiocarbon method, and for other absolute methods (optically stimulated luminescence (OSL) and cosmogenic nuclide dating) care must be taken with both sampling and interpretation because of inherent methodological assumptions (e.g., Aitken, 1998; Gosse and Phillips, 2001) and geological uncertainties (e.g., erosion, prior exposure and shielding issues associated with cosmogenic nuclide dating, Fabel and Harbor, 1999; Putkonen and Swanson, 2003; and incomplete bleaching of quartz and feldspar grains in glacial settings for OSL dating, e.g., Gemmell, 1988). Relative age control for some glacial sediments has been achieved using the stratigraphic position of glacial deposits relative to interglacial sediments (e.g., peats, the ages of which are occasionally constrained by U-series dating), and tephra (e.g., the Old Crow tephra that provides a youngest age limit for underlying glaciogenic sediments in North America; e.g., Ward et al., 2008). Available PGM terrestrial evidence for the EIS with currently available dating constraints is summarised in Fig. 1. Note that we make no judgement regarding the reliability of ages, and include sites only where the original authors specifically attribute glacial sediments/features to the PGM, where this is either identified as MIS 6 or the youngest Saalian/Illinoian glacial episodes. Our database for these PGM-specific data is available at the URL listed in the acknowledgements.

The mapped extents in Fig. 1 help to constrain the maximum PGM ice-sheet area, but are not indicative of ice-sheet thickness (i.e., topography, volume). Instead, model inversion techniques with varying assumptions and input datasets (e.g., Peltier, 2004; Lambeck et al., 2006; Abe-Ouchi et al., 2015) are needed to provide dynamic ice histories with volume, extent, and topographic constraints (see Stokes et al., 2015 for an overview on modelling past ice sheets). Ice-sheet extent, form, and thickness result from interactions between glaciological and climatological factors on local, regional, and global scales. Limits to ice-sheet extent include ice rheology (Glen, 1958) and ice-flow mechanisms driven by iceelevation gradients, including the ice-thickness/basal-melting negative feedback (Payne, 1995; Marshall and Clark, 2002), and variations in basal conditions such as topography, sub-glacial till rheology (e.g., Clark and Pollard, 1998; Licciardi et al., 1998), and geothermal heat flux (e.g., Pattyn, 2010). Regional ice thickness depends primarily on near-surface temperatures and rates of snow 
accumulation and ablation (e.g., Seguinot et al., 2014). In addition, the mass balance of an ice sheet can be affected by factors such as: dust deposition that alters snow and ice albedo (e.g., Krinner et al., 2006; Bar-Or et al., 2008); albedo feedbacks from changes in vegetation cover around the ice sheet (e.g., Gallimore and Kutzbach, 1996); and changes in the sources and pathways of moisture advection. Differences in these factors may account (partly) for the different spatial EIS extents between the PGM and LGM. For example, dust transportation is thought to have been more intense during the LGM than the PGM (e.g., Naafs et al., 2012). In addition, the PGM EIS was affected by large pro-glacial lakes, which (because of large heat capacities) can cool regional summer climates, and which also modify precipitation through meso-scale atmospheric feedbacks (e.g., Krinner et al., 2004; Colleoni et al., 2009). No geological evidence exists for such lakes during the LGM (Mangerud et al., 2004).

Even under favourable conditions for glaciation, other controls such as topographic (including ice-sheet) barriers may block moisture advection, limiting ice-sheet growth above a certain height (e.g., Kageyama and Valdes, 2000; Ullman et al., 2014; Liakka et al., 2016). Ice-sheet orography by itself affects local weather systems - e.g., lee-side cyclogenesis by increasing the advection of cold air, with impacts on precipitation - in addition to altering atmospheric stationary-wave patterns over the ice topography (e.g., Cook and Held, 1988; Roe and Lindzen, 2001; Abe-Ouchi et al., 2007; Löfverström et al., 2014). Such influences affect ice-sheet ablation and elevation through temperature changes at both local and regional scales (e.g., Roe and Lindzen, 2001; Liakka et al., 2012). For example, NAIS-elevation changes during the last glacial cycle altered both the position and strength of the North Atlantic jet stream (e.g., Kageyama and Valdes, 2000; Abe-Ouchi et al., 2007). This caused changes in North Atlantic storm tracks and European precipitation (Liakka et al., 2016): a higher NAIS results in a more zonal jet stream (Roe and Lindzen, 2001; Löfverström et al., 2014), with drier (wetter) conditions in northern (southern) Europe (Löfverström et al., 2014). Conversely, a small NAIS has limited impact on European precipitation (Liakka et al., 2016). Other impacts on the storm track relate to sea-ice and sea-surface temperature distributions (Kageyama and Valdes, 2000): during the LGM, for example, extensive Arctic/North Atlantic sea-ice cover is thought to have caused considerable southward storm-track displacement (e.g., Kageyama et al., 1999). These various influences likely account for the significant difference in EIS distributions between the PGM and LGM (e.g., Liakka et al., 2016), given that $(i)$ the PGM had less extensive and seasonally open sea-ice conditions, relative to extensive and severe sea-ice conditions during the LGM (e.g., Spielhagen et al., 2004; Nørgaard-Pedersen et al., 2007; Polyak et al., 2010; de Vernal et al., 2013; Arndt et al., 2014; Löwemark et al., 2016), and (ii) the NAIS was smaller/lower during the PGM than during the LGM (e.g., Svendsen et al., 2004; Ehlers et al., 2011a).

Stationary wave patterns also affect the southernmost boundary of the NAIS, by enhancing or decreasing local ablation (Cook and Held, 1988; Roe and Lindzen, 2001; Liakka et al., 2012). Certain configurations induce warming in the northwest of North America, cooling over the central continent, and a warm anomaly in the east; this pattern facilitates southward ice-sheet expansion over the central continent, and poleward deflection of the ice margin in the east (Liakka et al., 2012). A reduced wavelength of the stationary wave - a function of differences in the zonal-mean background state, latitude, and size of the NAIS (Cook and Held, 1988; Ringler and Cook, 1997; Liakka et al., 2012, 2016) - tends to shift the centre of mass eastward, which facilitates southward penetration of a NAIS lobe along the eastern continental boundary (Roe and Lindzen, 2001). Ice-volume hysteresis may also be (partly) related to variations in the latitudinal extent of the Laurentide ice sheet (Abe-Ouchi et al., 2013). Overall, differences between PGM and LGM reconstructions of the NAIS likely reflect differences in the zonal-mean atmospheric circulation and the induced temperature anomalies (e.g., Liakka et al., 2012).

\subsection{PGM ice-volume estimates}

We now use our PGM-LGM $\Delta \mathrm{z}$ of $21 \pm 14 \mathrm{~m}$ to calculate ranges of PGM ice volumes for the EIS and NAIS, based on published icesheet reconstructions (Table 1). Relative to an LGM sea-level drop of about $130 \mathrm{~m}$, our $\Delta z$ suggests a PGM sea-level drop of $109 \pm 14 \mathrm{~m}$. A selection of recent ice-volume estimates for the PGM and LGM ice sheets is given in Table 1, with a focus on models that are constrained by geological or sea-level evidence, which illustrates the evolution of estimates within the last decade (notably, a reduction in LGM EIS estimates). Comparisons between estimates may be complicated by differing methods (e.g., whether estimates are constrained by glacio-geomorphological observations), the assumptions made when calculating mSLE (e.g., choice of water/ice densities, and whether the modern ocean area is used or a reduced value due to sea-level lowering), and incremental model development, which can lead to differences between originally published values and those from subsequent modelling.

Assuming a PGM sea-level drop of $109 \pm 14$ m, a PGM EIS volume of 33-53 m $\mathrm{SLE}$, and comparable Antarctic excess ice volume between the PGM and LGM (assuming $17 \mathrm{~m}_{\mathrm{SLE}}$ as an upper bound, based on geologically constrained glaciological modelling; Table 1), the inferred values imply a North American NAIS volume as small as 59 to $39 \mathrm{~m}_{\mathrm{SLE}}\left( \pm 14 \mathrm{~m}_{\mathrm{SLE}}\right.$ ), respectively. A caveat applies with respect to attribution of component contributions to the overall sea-level drop, namely that various indicators for the maximum EIS extent may represent different glacial advance phases at different locations (Svendsen et al., 2004; Lambeck et al., 2006; Hughes et al., 2013; Colleoni et al., 2016) (Fig. 1). In that case, PGM EIS volume may have been overestimated; a conservative limit may be calculated for the PGM NAIS by assuming a $29 \mathrm{~m}_{\text {SLE }}$ limit for the PGM EIS, similar to the upper limit for the LGM EIS and in agreement with ice-sheet models that suggest a maximum EIS of $40 \mathrm{~m}_{\mathrm{SLE}}$ (Bintanja et al., 2005; Abe-Ouchi et al., 2015) (which conflicts with datadriven estimates of 50-71 $\mathrm{m}_{\mathrm{SLE}}$; Table 1 ). This conservative limit for PGM NAIS volume is $63 \pm 14 \mathrm{~m}_{\text {SLE }}$, so that we infer a PGM NAIS ice-volume range of $39-63 \mathrm{~m}_{\mathrm{SLE}}\left( \pm 14 \mathrm{~m}_{\mathrm{SLE}}\right)$ from our $\Delta z$ assessment, while previous PGM NAIS reconstructions infer a volume of 30-84 m SLE (Table 1). In contrast to our PGM NAIS ice-volume range of 39-63 $\mathrm{m}_{\mathrm{SLE}}\left( \pm 14 \mathrm{~m}_{\mathrm{SLE}}\right)$, LGM NAIS estimates range over 51-94 $\mathrm{m}_{\mathrm{SLE}}$ (Table 1).

Overall, our analysis indicates that PGM global land-based ice volume was smaller than LGM global land-based ice volume; more robust analysis requires improved individual component icevolume estimates. A strong case exists for a small PGM NAIS, from a combination of climate and ice-sheet modelling (Colleoni et al., 2014, 2016; Wekerle et al., 2016), GIA modelling (Potter and Lambeck, 2003; Lambeck et al., 2006, 2010, 2017; Wainer et al., 2017), and North Atlantic IRD observations (Obrochta et al., 2014), in addition to our sea-level assessment (this study).

\section{Implications of PGM-LGM ice-volume differences}

\subsection{Implications for concepts of glacial inception}

To provide a wider climatic context to the PGM-LGM icevolume differences documented in this study, we also determined PGM-LGM contrasts in other key climate parameters (Table 4). For this analysis, we performed Monte-Carlo-style 
Table 4

PGM-LGM comparisons between important climate parameters.

\begin{tabular}{|c|c|c|c|c|c|c|}
\hline & LGM & $95 \%$ bounds & PGM & $95 \%$ bounds & $\Delta_{\text {PGM-LGM }}$ & $95 \%$ bounds \\
\hline Insolation $\left(\mathrm{W} \mathrm{m}^{-2}\right)^{\mathrm{a}}$ & 464.34 & & 463.97 & & -0.37 & \\
\hline Summer energy (Ga-Joules $\left.\mathrm{m}^{-2}\right)^{\mathrm{b}}$ & 2.89 & & 2.97 & & 0.08 & \\
\hline $\mathrm{CO}_{2}$ (p.p.m.v.) ${ }^{\mathrm{c}}$ & $182.17(181.59)$ & $4.27(1.45)$ & $188.79(188.32)$ & $6.72(1.41)$ & $6.62(6.74)$ & $7.96(2.02)$ \\
\hline$\Delta F_{\mathrm{CO} 2}\left(\mathrm{~W} \mathrm{~m}^{-2}\right)^{\mathrm{c}, \mathrm{d}, \mathrm{e}, \mathrm{f}, \mathrm{g}, \mathrm{h}, \mathrm{j}}$ & $-2.41(-2.43)$ & $0.16(0.06)$ & $-2.11(-2.12)$ & $0.20(0.05)$ & $0.30(0.32)$ & $0.26(0.08)$ \\
\hline $\mathrm{CH}_{4}$ (p.p.b.v.) & $354.20(356.49)$ & $18.24(17.45)$ & $354.04(350.02)$ & $42.63(7.59)$ & $-0.16(-6.47)$ & $46.37(19.03)$ \\
\hline$\Delta F_{\mathrm{CH} 4}\left(\mathrm{~W} \mathrm{~m}^{-2}\right)^{\mathrm{i}, \mathrm{j}}$ & $-0.25(-0.25)$ & $0.02(0.01)$ & $-0.25(-0.25)$ & $0.04(0.01)$ & $0.00(-0.01)$ & $0.05(0.02)$ \\
\hline$\Delta F_{\mathrm{GHG}}\left(\mathrm{W} \mathrm{m}^{-2}\right)^{\mathrm{j}}$ & $-3.03(-3.03)$ & $0.36(0.09)$ & $-2.74(-2.73)$ & $0.38(0.09)$ & $0.29(0.30)$ & $0.52(0.13)$ \\
\hline Antarctic Temperature $\left({ }^{\circ} \mathrm{C}\right)^{\mathrm{k}}$ & $-9.60(-9.61)$ & $3.24(0.77)$ & $-9.03(-9.03)$ & $3.24(0.72)$ & $0.57(0.58)$ & $4.58(1.05)$ \\
\hline Antarctic Temperature $\left({ }^{\circ} \mathrm{C}\right)^{1}$ & $-9.18(-9.21)$ & $3.25(0.78)$ & $-8.49(-8.50)$ & $3.33(0.87)$ & $0.69(0.71)$ & $4.65(1.17)$ \\
\hline$\Delta \delta^{18} \mathrm{O}_{\text {benthic }}$ stack $^{\mathrm{m}}$ & 1.78 & 0.10 & 1.77 & 0.10 & -0.01 & 0.14 \\
\hline
\end{tabular}

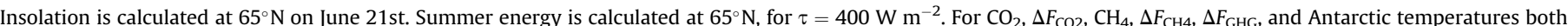
median and probability maximum (latter in parenthesis) values and their $95 \%$ bounds are reported. The standard error associated to the $\Delta \delta^{18} \mathrm{O}_{\mathrm{benthic}}$ stack is $0.05 \%$.

a Laskar et al., 2004.

b Huybers, 2006.

c Monnin et al., 2001.

d Monnin et al., 2004.

e Schmitt et al., 2012.

f Schneider et al., 2013.

g Landais et al., 2013.

h Ahn and Brook, 2014.

i Loulergue et al., 2008.

j Köhler et al., 2010.

k Stenni et al., 2010.

${ }^{1}$ Parrenin et al., 2013.

m Lisiecki and Raymo, 2005.

probabilistic assessments ( $n=10,000$ simulations) based on the uncertainties associated with the various records. For $\mathrm{CO}_{2}, \mathrm{CH}_{4}$, and Antarctic temperature records (Monnin et al., 2001, 2004; Loulergue et al., 2008; Lourantou et al., 2010; Stenni et al., 2010; Schmitt et al., 2012; Schneider et al., 2013; Landais et al., 2013; Parrenin et al., 2013; Ahn and Brook, 2014), we account for uncertainties associated with chronology (AICC 2012, Veres et al., 2013; Bazin et al., 2013) and proxy measurement in each record to determine the $68 \%\left(16^{\text {th }}-84\right.$ th percentile $)$ and $95 \%\left(2.5^{\text {th }}-97.5\right.$ th percentile) probability intervals, the median ( $50^{\text {th }}$ percentile), and the probability maximum (modal value) with its $95 \%$ probability interval (e.g., Grant et al., 2012; Rohling et al., 2014; Marino et al., 2015). We probabilistically calculate greenhouse gas (GHG) components of Earth's radiative balance $\left(\Delta F_{\mathrm{CO} 2}, \Delta F_{\mathrm{CH} 4}\right.$, and $\left.\Delta F_{\mathrm{GHG}}\right)$ from ice-core time series of $\mathrm{CO}_{2}$ and/or $\mathrm{CH}_{4}$, referencing radiative forcing estimates to the values at AD1000 (cf. Rohling et al., 2012). This probabilistic analysis accounts for $(i)$ chronological and measurement uncertainties for $\mathrm{CO}_{2}$ (Monnin et al., 2001, 2004; Schmitt et al., 2012; Schneider et al., 2013; Landais et al., 2013; Ahn and Brook, 2014) and/or $\mathrm{CH}_{4}$ time series (Loulergue et al., 2008), and (ii) uncertainties associated with conversion of $\mathrm{CO}_{2}$ and/or $\mathrm{CH}_{4}$ to $\Delta F_{\mathrm{CO} 2}, \Delta F_{\mathrm{CH} 4}$, and $\Delta F_{\mathrm{GHG}}$. Input data for the Monte Carlo routines are the ice-core 'gas ages' with uncertainties of the AICC2012 chronology (Veres et al., 2013; Bazin et al., 2013) and $\mathrm{CO}_{2}$ and/or $\mathrm{CH}_{4}$ data with analytical uncertainties (Monnin et al., 2001, 2004; Loulergue et al., 2008; Schmitt et al., 2012; Schneider et al., 2013; Landais et al., 2013; Ahn and Brook, 2014). Each data point was separately and randomly sampled $n$ times within its uncertainties and converted to $\Delta F$ values, using the equations of Köhler et al. (2010) with their uncertainties. Each iteration was interpolated linearly and the probability distribution was assessed at each time step to determine probability intervals and probability maxima. Finally, minima in the median and probability maximum of each climate parameter (with 95\% probability bounds) were determined within the 19-26.5 kyr ago (cf. Clark et al., 2009) and 138-155 kyr ago intervals for the LGM and PGM, respectively. LGM and PGM minima for summer insolation and energy at $65^{\circ} \mathrm{N}$ were determined directly from the original datasets (Laskar et al., 2004;
Huybers, 2006) through the same time intervals. In our analysis we also considered deep-sea benthic foraminiferal carbonate $\delta^{18} \mathrm{O}$ from a stack of 57 globally distributed global records (Lisiecki and Raymo, 2005): PGM and LGM maxima are reported as anomalies ( $\Delta \delta^{18} \mathrm{O}_{\text {benthic }}$ ) with respect to the mean of the most recent 2 kyrs.

Our assessment reveals similar values of commonly used key climate parameters between the two glacial maxima (Table 4), in contrast to the significant sea-level difference between the PGM and LGM (section 2.4). The identified contrasts between the PGM and LGM highlight a need for future research to unravel the causes of ice-age development into either a PGM-like, or an LGM-like mode. Different PGM and LGM ice distributions between North America and Eurasia imply different moisture fluxes over the continents between these glacial cycles, partly due to interactions between NAIS size and atmospheric dynamics (e.g., Colleoni et al., 2016; Liakka et al., 2016), and partly due to complex interacting processes that drive glaciations toward large- or small-NAIS sizes (e.g., Colleoni et al., 2011). For example, not only summer insolation and GHG forcing (Table 4), but also ice-albedo feedbacks, vegetation-albedo feedbacks, dust deposition on snow/ice, sea-ice expansion, and sea surface temperature reduction need to be considered (e.g., Oglesby, 1990; Calov et al., 2009; Clark et al., 2009; Colleoni et al., 2011; Abe-Ouchi et al., 2013; Liakka et al., 2016). Moreover, ice-sheet accumulation may not be related directly to the commonly used summer insolation at specific latitudes, but may also be affected (more) by insolation in other seasons, particularly spring (Colleoni et al., 2011; Jakobsson et al., 2014a). Ice-sheet nucleation may, in addition, depend on chaotic aspects of the weather/climate system; for example, successive winters with heavy snowfall may - almost randomly - cause some locations to receive an initial snow cover with enough volume and albedo feedback to ensure its survival and subsequent growth potential (e.g., Oglesby, 1990). Finally, modelling studies (e.g., Abe-Ouchi et al., 2013) indicate that glacial culminations like the PGM and LGM reflect the outcome of temporal developments in forcings and feedbacks through the preceding glacial cycle that include insolation (e.g., Laskar et al., 2004; Colleoni et al., 2011), $\mathrm{CO}_{2}$ and $\mathrm{CH}_{4}$ concentrations (Monnin et al., 2001; Loulergue et al., 2008; Schmitt 
et al., 2012; Schneider et al., 2013; Landais et al., 2013), and sea level/ice volume (e.g., Waelbroeck et al., 2002; Rohling et al., 2009, 2014; Elderfield et al., 2012; Grant et al., 2014), and also in state variables such as surface and deep-sea temperature (e.g., Stenni et al., 2010; Elderfield et al., 2012; Parrenin et al., 2013; Rohling et al., 2012, 2014; Martínez-Botí et al., 2015; Snyder, 2016a,b). Climate simulations by Colleoni et al. (2014) suggest that orbital and greenhouse-gas changes for the penultimate glacial cycle were more favourable for glacial inception over Eurasia than over North America, relative to the last glacial cycle. Targeted high-resolution, coupled modelling of full glacial cycles on a global scale may further improve understanding of differences between the PGM and LGM, and other glacial maxima, and use of stable O-isotope-enabled models may then help to explore the major issue highlighted in section 4.3.

\subsection{Glacioisostatic corrections to Last Interglacial sea level}

Proxy-based sea-level reconstructions generally refer to a location-specific relative sea level (RSL). This is related to global mean sea level (GMSL) via a glacial isostatic correction: GIA correction $=$ GMSL - RSL. Different PGM and LGM ice-mass distributions may critically affect last interglacial glacioisostatic corrections, and therefore reconstructions of LIG GMSL. We present an exploration of this influence using several hypothetical scenarios (Figs. 4-7; Table 5). We solve the sea-level equation using the Kendall et al. (2005) method, which is adapted to account for feedback from Earth's rotational vector (Mitrovica et al., 2005). The model takes into account self-gravitational feedbacks, moving shorelines, and marine-terminating ice sheets, and the sea-level equation is solved in an iterative, pseudo-spectral manner (Mitrovica et al., 2005; Tamisiea, 2011; Williams, 2016) that incorporates a spherically symmetric Earth representation.

We use three model outputs: (a) a global grid of RSL values generated for a suite of earth-model parameterisations; (b) an RSL curve for several key reconstruction sites; and (c) a GMSL curve where ocean volume and area are corrected for GIA effects at each modelled time step. We model GIA for representative sites for key fossil-coral locations at Barbados $\left(13.116{ }^{\circ} \mathrm{N}, 59.542{ }^{\circ} \mathrm{W}\right)$, Tahiti $\left(17.567{ }^{\circ} \mathrm{S}, 149.58{ }^{\circ} \mathrm{W}\right)$, Western Australia $\left(22.32^{\circ} \mathrm{S}, 113.8^{\circ} \mathrm{E}\right)$, and the Seychelles ( $4.67{ }^{\circ}$ S, $55.5^{\circ}$ E) (e.g., Fairbanks, 1989; Stirling et al., 1995; Bard et al., 1996; Israelson and Wohlfarth, 1999 - as early examples from the extensive literature summarised by Hibbert et al., 2016). Hanish Sill, Bab-el-Mandab Strait (13.733 ${ }^{\circ} \mathrm{N}$, $42.533^{\circ} \mathrm{E}$ ), is the control point for Red Sea reconstructions, as is Camarinal Sill, Strait of Gibraltar $\left(35.92^{\circ} \mathrm{N}, 5.72{ }^{\circ} \mathrm{W}\right)$, for Mediterranean Sea reconstructions (Siddall et al., 2003; Grant et al., 2012, 2014; Rohling et al., 2014). Finally, we model a point for the easternmost Mediterranean, at Rosh Hanikra $\left(33.093^{\circ} \mathrm{N}, 35.105^{\circ} \mathrm{E}\right)$, for which a detailed LIG coastal stratigraphic sequence has been published (Sivan et al., 2016).

GIA assessment requires an ice history, which is a series of timepoint files with ice-height data on a global grid (here a $512 \times 256$ Gauss-Legendre grid). We developed four hypothetical ice histories based on the arguments in this study, in 2-kyr time steps (Table 5, Fig. 5). We emphasise that these are idealised hypothetical scenarios, designed to test the GIA response at each key location. For more conclusive GIA corrections, extensive reconstruction is needed of the time development of total ice mass and its distribution between continental locations, at discrete time steps through entire glacial cycles.

Our hypothetical "ICE-1" ice history (Fig. 5a) is a version of the ICE-5G model (Peltier, 2004) that is extended to cover 2 identical glacial cycles, placed before and after a 14-kyr interglacial highstand between 130 and 116 ka (Dutton and Lambeck, 2012). Because of the way this is constructed by copying the last glacial cycle, the peak amplitude for the PGM happens to fall on $152 \mathrm{ka}$. Our further hypothetical scenarios keep timing-structure the same, and only change total ice-volume amplitudes and relative NAIS:EIS ice-mass distributions as explained below. Amplitude changes
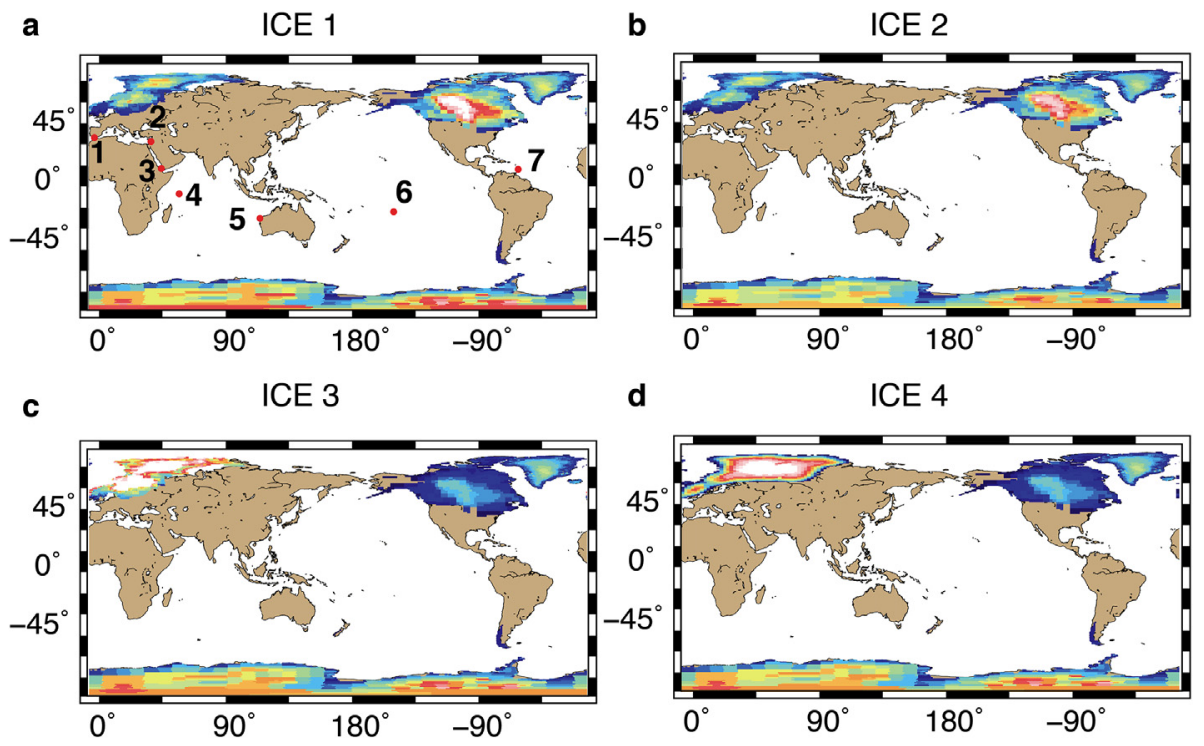

d

ICE 4
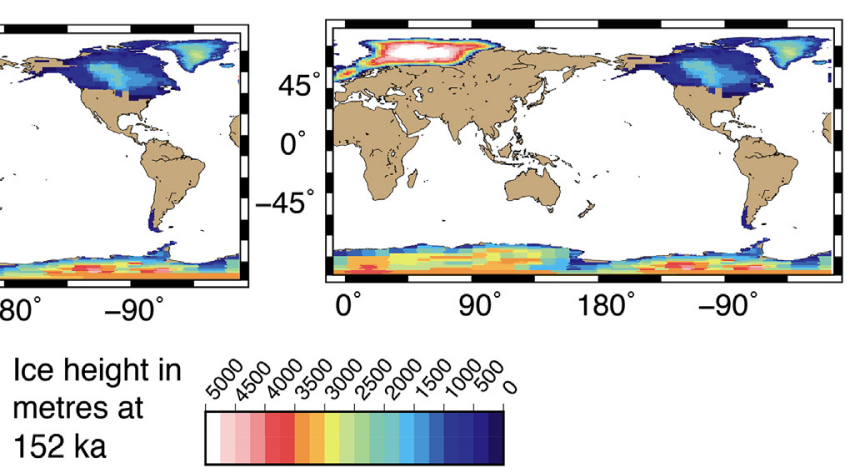

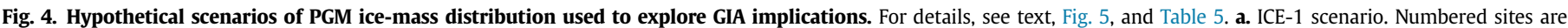

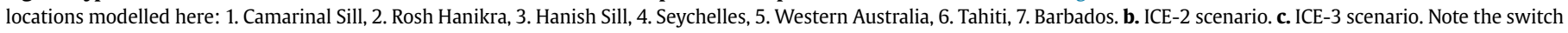
in ice heights compared to ICE-2. d. ICE-4 scenario. Note the different geographical boundaries of the EIS, relative to other scenarios. 
a

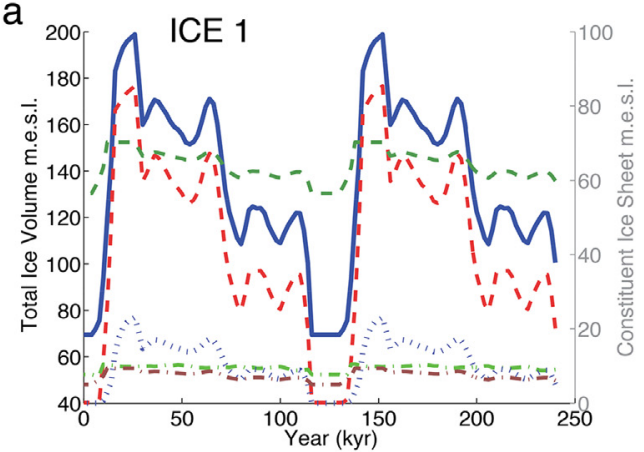

C

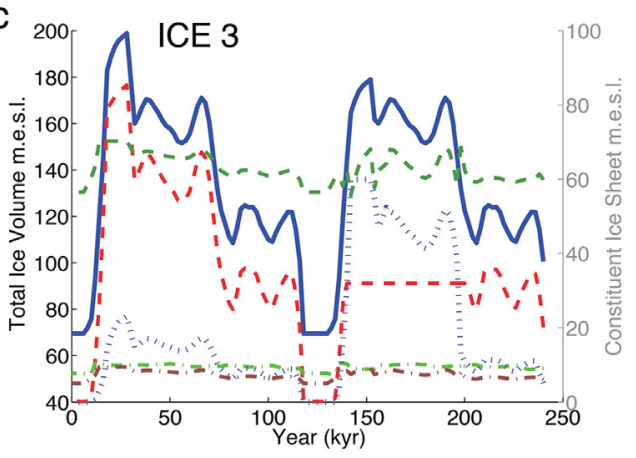

b

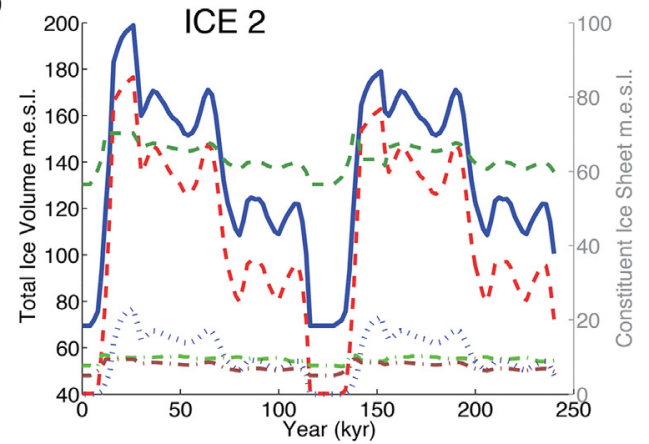

d

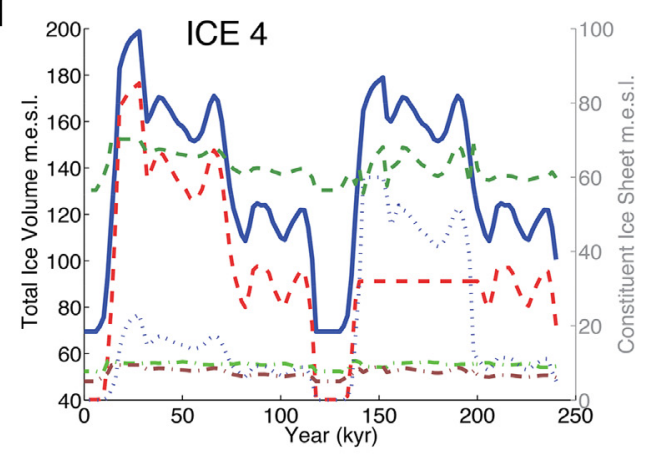

$$
\begin{array}{lll}
\text {-Total } & \text {-.. Greenland } & \text { WAIS } \\
\text { - - North American } \cdots \cdot \text { Eurasian } & - \text { - EAIS }
\end{array}
$$

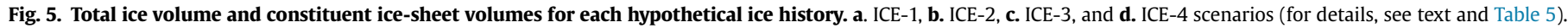

prior to $26 \mathrm{ka}$ are scaled according to the SPECMAP curve (Imbrie et al., 1984). Note that our scenarios are hypothetical and use arbitrary values from within ranges outlined above, to investigate the potential sense and scale of impacts; more definitive reconstructions are contingent upon future research to determine ice-mass distributions, Antarctic contributions, and GIA model developments (e.g., allowing for incorporation of inhomogeneous Earth models), etc.

In our hypothetical "ICE-2" ice history (Fig. 5b), the impact of reduced ice mass at the PGM is compared with the LGM, while keeping constant the NAIS:EIS mass-distribution proportionality. ICE-2 features a $16 \%$ sea-level change for the PGM, from an LGMlike $-130 \mathrm{~m}$ to a reduced value of $-109 \mathrm{~m}$. A $16 \%$ total icevolume reduction at maximum glaciation represents $\sim 21 \mathrm{~m}_{\mathrm{SLE}}$ of change when applied to the ICE-5G model. Change to an ice history requires adjustment over a sequence of time steps. To create ICE-2 by changing the PGM of ICE-1 (152 kyr ago), we also scaled the surrounding 154,152, 150, 148, 146, 144 and 142 ka time points: 154 ka has a $14 \%$ ice reduction; 152,150 , and 148 ka have $16 \%$ reduction; 146 ka has $10 \%$ reduction; and 144 and 142 ka have $8 \%$ reduction, relative to ICE-1.

Hypothetical ice history "ICE-3" (Fig. 5c) was designed to investigate how a changed PGM ice-mass distribution (i.e., smaller NAIS, larger EIS) affects RSL histories at our study sites. We constrained the NAIS to $32 \mathrm{~m}_{\mathrm{SLE}}$ between 200 and $140 \mathrm{ka}$, and EIS to a $60 \mathrm{~m}_{\mathrm{SLE}}$ maximum between 152 and $142 \mathrm{ka}$, and left the interglacial to present day identical to ICE-1 and ICE-2. Temporal scaling for the EIS through the penultimate glacial cycle is applied as follows (Fig. 5c): between 236 and $198 \mathrm{ka}$, we scaled the EIS volume of ICE2 by a factor of 1.25 , between 196 and 162 ka we scaled it by a factor of 3, from 160 to $154 \mathrm{ka}$ we scaled it by a factor of 3.2, from 140 to $136 \mathrm{ka}$ we scaled it by a factor 5.5, and from 152 to $142 \mathrm{ka}$ we held the ice volume at $60 \mathrm{~m}_{\mathrm{SLE}}$. All these adjustments were made within the geographical boundaries set out by ICE-5G. Within the extended ICE-1 glacial history, the NAIS reached a greater ice volume early in the penultimate glacial cycle. To accommodate this in ICE-3, we allowed initial penultimate glacial variation to the NAIS (up to $36 \mathrm{~m}_{\mathrm{SLE}}$ ), but when its ice volume would have increased further we capped it at $32 \mathrm{~m}_{\mathrm{SLE}}$. The required variation for total global volume was then distributed into the EIS, and any remnant required volume was pushed into the East and West Antarctic ice sheets (Fig. 5c).

In a hypothetical ice history "ICE-4" (Fig. 5d), impacts of allowing the EIS to occupy a larger area are assessed (cf. Fig. 1). In ICE-3, the EIS remained within its ICE-5G boundaries despite giving it greater mass. In ICE-4, we used the EIS distribution of de Boer et al. (2014), and spliced it into ICE-3 instead of the ICE-5G extent (EIS only). This new penultimate glacial EIS was scaled to match ICE-3 volume variations, with the same rule as applied to NAIS volume. Resulting ice-volume variations are identical to ICE-3 for all ice sheets; the only difference is the EIS spatial distribution.

All ice histories were run using a range of 495 Earth models that comprise 3 parameters for lithosphere thickness (71, 96, and $120 \mathrm{~km}), 11$ parameters for upper mantle viscosity $\left(1 \times 10^{20}\right.$ to $\left.1 \times 10^{21} \mathrm{~Pa} \mathrm{~s}\right)$, and 15 parameters for lower mantle viscosity $\left(2 \times 10^{21}\right.$ to $\left.5 \times 10^{22} \mathrm{~Pa} s\right)$. Results at each location are compared with an LGM-like PGM (ICE-1) (Table 6). Appendix Ib provides a global representation of the range in peak (maximum) RSL results within the LIG across all 495 Earth models, for each of our ice histories. While results for the LIG (Fig. 7) and for the wider interval of 160-110 ka (Fig. 6) are - for clarity - only shown for a VM2-like Earth model (with lithosphere thickness of $96 \mathrm{~km}$, and upper and lower mantle viscosities of $5 \times 10^{20}$ and $2.5 \times 10^{21}$ Pa s, respectively), they can be compared to Fig. 8 to understand the range of response possible across our wide suite of Earth parameters (Table 6). 

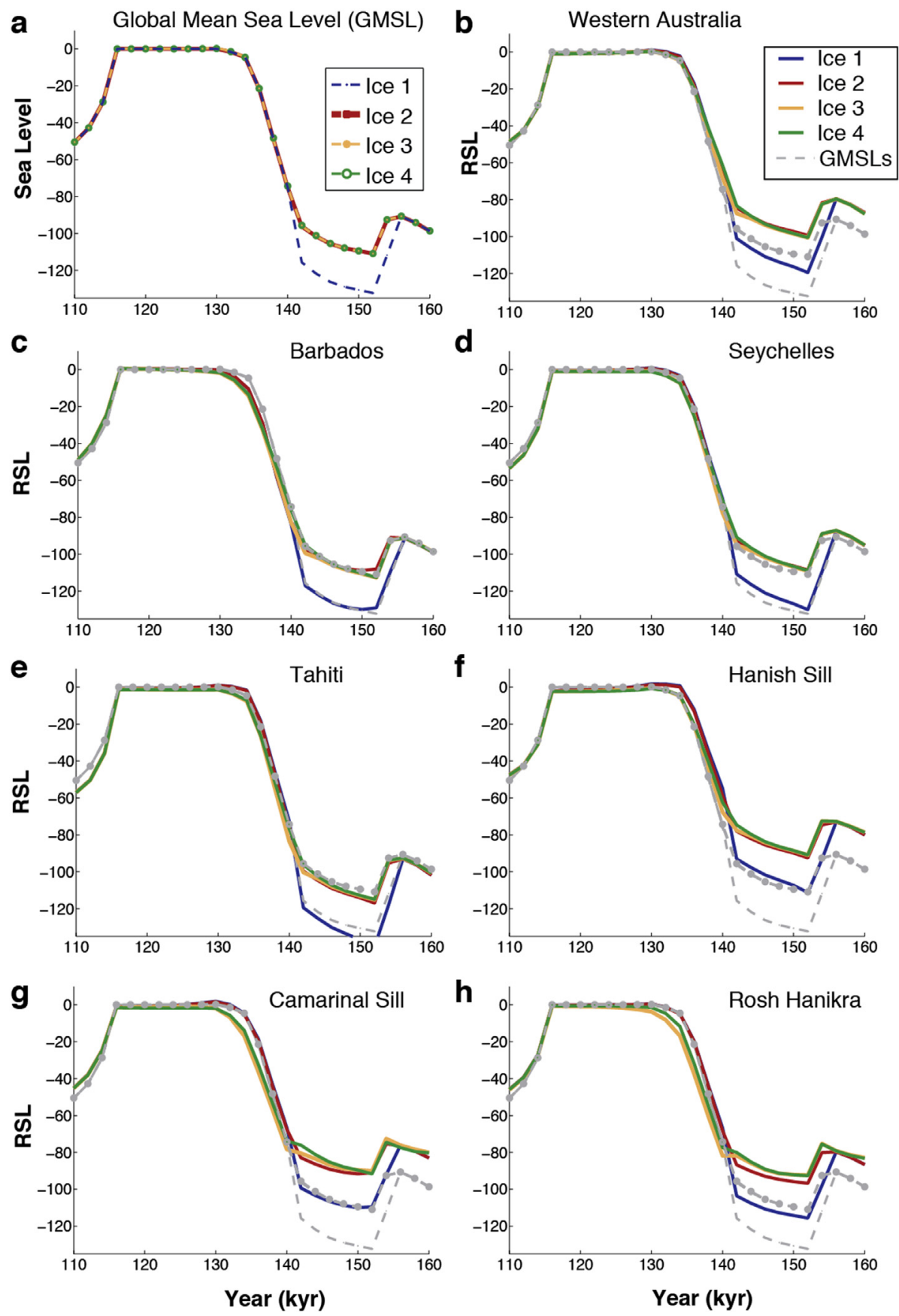

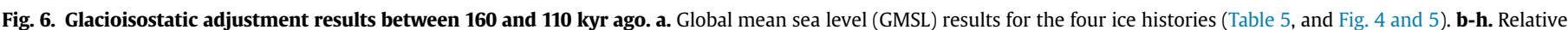

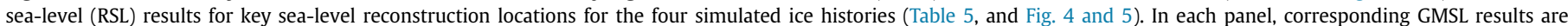

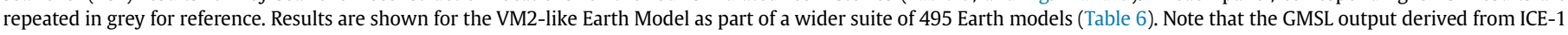
tracks a different ice volume, relative to GMSL outputs from scenarios ICE-2, -3 , and -4 , which over-plot one another.

Reviewing the RSL response at the LIG onset ( 130 ka), we find that key differences in sensitivity (to Earth model) and amplitude of RSL differences between a small (ICE-1, 2) or large EIS (ICE-3, 4) are systematic across locations. Some sites have relatively low sensitivity to, and small amplitude offset for, this change (Western Australia, Barbados). Others have intermediate impact $(2-6 \mathrm{~m}$ difference, with Earth-model sensitivity characterised in the range of 1-2.5 m; Hanish Sill, Tahiti, Seychelles), and some have even larger impacts, with additional sensitivity to ice-sheet configuration and Earth model (Camarinal Sill, Rosh Hanikra) (Fig. 7, Table 6).
Our results are explored in a global context for three different representative Earth models (Fig. 8 and Table 7). Each panel in Fig. 8 represents the difference between peak (maximum) RSL within the last interglacial for two ice histories: ICE 1 for an LGM-like PGM, and ICE 3 for a PGM with reduced total ice volume, larger EIS, and smaller NAIS, albeit with constant geographical ice-sheet boundaries. Fig. 8a, b, and c represent data generated using Earth models $\mathrm{E} 1, \mathrm{E} 2$, and E3, respectively (Table 7). All three panels indicate that a variation in PGM ice volume and distribution is likely to result in a change to the GIA correction during the interglacial period, and that 

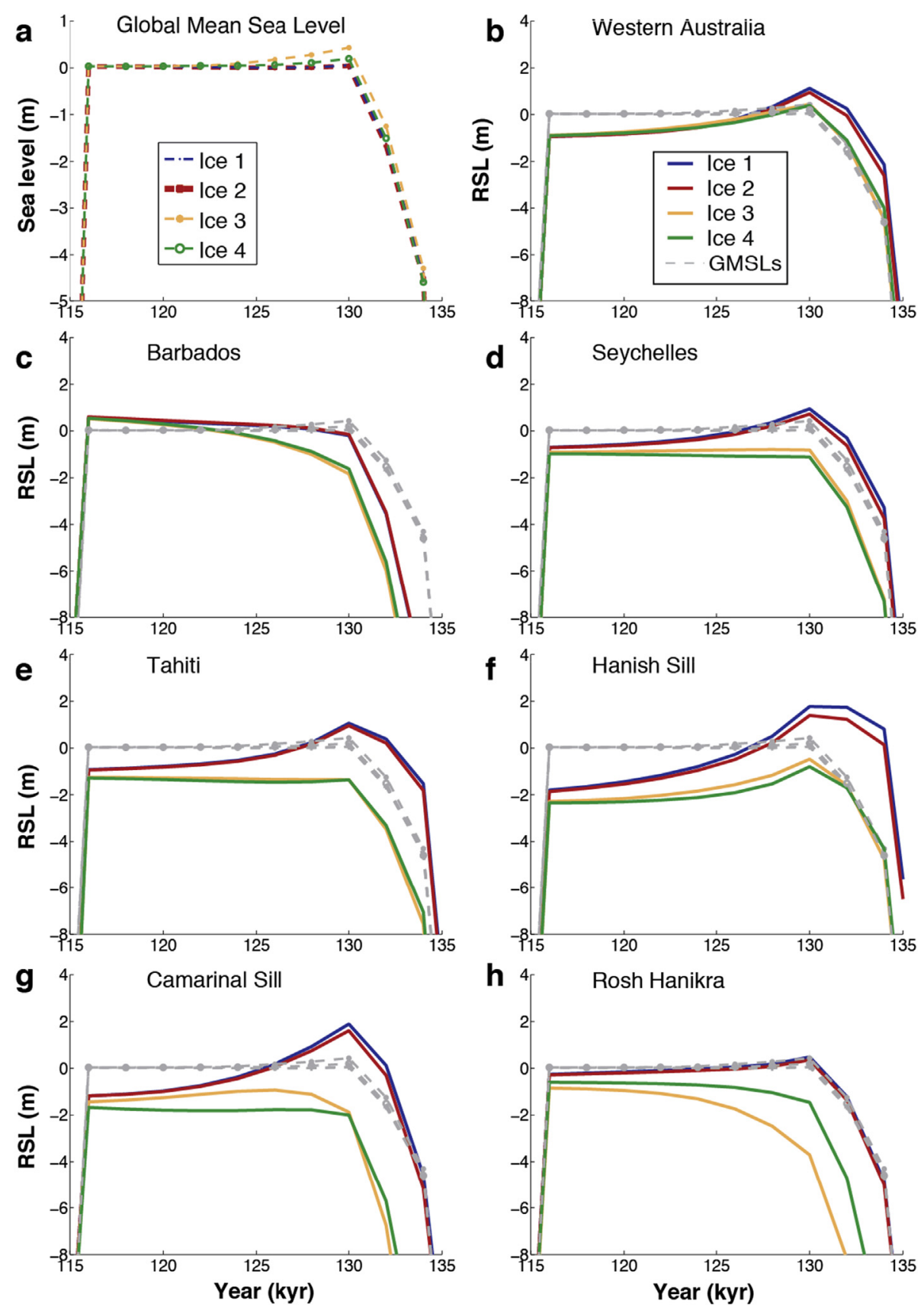

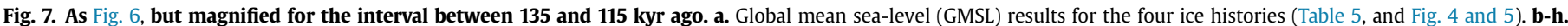

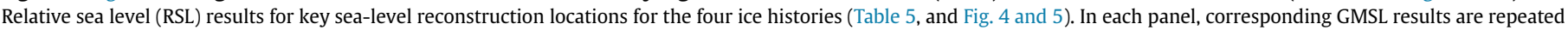

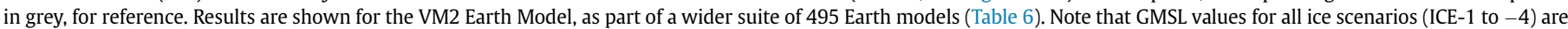
virtually indistinguishable through the interglacial period because they track the same global ice volume.

Table 5

Characteristics of hypothetical ice histories for GIA modelling.

\begin{tabular}{|c|c|c|c|c|}
\hline \multirow[t]{2}{*}{ Ice History } & \multicolumn{4}{|l|}{ Scenario Features } \\
\hline & Contains a 14-kyr LIG highstand & Reduced ice volume through PGM relative to LGM & Small NAIS, large EIS at PGM & Changed extent of PGM EIS \\
\hline ICE 1 & $\mathrm{X}$ & & & \\
\hline ICE 2 & $\mathrm{X}$ & $\mathrm{X}$ & & \\
\hline ICE 3 & $\mathrm{X}$ & $\mathrm{X}$ & $\mathrm{X}$ & \\
\hline ICE 4 & $\mathrm{X}$ & $\mathrm{X}$ & $\mathrm{X}$ & $\mathrm{X}$ \\
\hline
\end{tabular}

the magnitude of this GIA correction depends strongly on the choice of Earth model. Variation in LIG peak RSL between ICE-1 and
ICE-3 for E1 ranges from -2 to $+4 \mathrm{~m}$ for the sites considered here (Fig. 8a) and corresponds to 0 to $+2.9 \mathrm{~m}$ changes in the GIA 
Table 6

RSL at each study site for each ice-history scenario.

\begin{tabular}{|c|c|c|c|c|c|c|}
\hline \multirow{2}{*}{$\frac{\text { PGM (152 ka) }}{\text { Location }}$} & \multicolumn{2}{|l|}{ ICE 2 - ICE1 } & \multicolumn{2}{|l|}{ ICE 3 - ICE 1} & \multicolumn{2}{|l|}{ ICE 4 - ICE 1} \\
\hline & Mean Difference & Standard Deviation & Mean Difference & Standard Deviation & Mean Difference & Standard Deviation \\
\hline Western Australia & 19.8 & 0.4 & 18.1 & 0.7 & 17.9 & 0.8 \\
\hline Hanish Sill & 19.2 & 0.6 & 22.1 & 1.9 & 22.2 & 1.7 \\
\hline Camarinal Sill & 18.0 & 0.3 & 18.1 & 3.5 & 17.9 & 1.9 \\
\hline Rosh Hanikra & 19.2 & 0.2 & 24.1 & 4.3 & 24.8 & 3.9 \\
\hline Tahiti & 23.9 & 0.5 & 26.4 & 1.5 & 26.5 & 1.3 \\
\hline Barbados & 20.6 & 0.3 & 15.6 & 0.9 & 15.3 & 1.2 \\
\hline Seychelles & 21.1 & 0.6 & 20.9 & 0.7 & 21.1 & 0.7 \\
\hline Start of LIG (130 ka) & ICE 2 - ICE1 & & ICE 3 - ICE 1 & & ICE 4 - ICE 1 & \\
\hline Location & Mean Difference & Standard Deviation & Mean Difference & Standard Deviation & Mean Difference & Standard Deviation \\
\hline Western Australia & -0.4 & 0.2 & -1.3 & 0.7 & -1.1 & 0.8 \\
\hline Hanish Sill & -0.7 & 0.3 & -5.5 & 2.5 & -5.1 & 2.1 \\
\hline Camarinal Sill & -0.1 & 0.2 & -12.7 & 5.2 & -7.5 & 3.0 \\
\hline Rosh Hanikra & -0.2 & 0.1 & -15.8 & 7.2 & -11.0 & 6.3 \\
\hline Tahiti & -0.5 & 0.3 & -5.4 & 1.9 & -5.3 & 1.9 \\
\hline Barbados & 0.1 & 0.2 & -0.2 & 1.9 & 0.0 & 2.1 \\
\hline Seychelles & -0.3 & 0.3 & -2.2 & 1.0 & -2.5 & 1.1 \\
\hline End of LIG (116 ka) & ICE 2 - ICE1 & & ICE 3 - ICE 1 & & ICE 4 - ICE 1 & \\
\hline Location & Mean Difference & Standard Deviation & Mean Difference & Standard Deviation & Mean Difference & Standard Deviation \\
\hline Western Australia & -0.1 & 0.1 & -0.2 & 0.6 & -0.1 & 0.7 \\
\hline Hanish Sill & -0.2 & 0.2 & -2.3 & 1.7 & -2.1 & 1.4 \\
\hline Camarinal Sill & 0.0 & 0.1 & -5.2 & 4.4 & -2.6 & 2.0 \\
\hline Rosh Hanikra & -0.1 & 0.1 & -7.2 & 5.4 & -5.5 & 4.5 \\
\hline Tahiti & -0.2 & 0.2 & -2.2 & 1.4 & -2.2 & 1.4 \\
\hline Barbados & 0.0 & 0.1 & 0.6 & 1.6 & 0.7 & 1.9 \\
\hline Seychelles & -0.1 & 0.1 & -0.6 & 0.3 & -0.7 & 0.5 \\
\hline
\end{tabular}

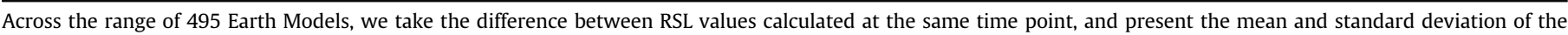
distribution of values across the 495 Earth models.

correction between the two scenarios. Repeating this exercise for the seven locations considered for all Earth models - given that peak RSL varies markedly between Earth models (Fig. 8b and c) the difference between GIA corrections for ICE- 1 and ICE-3 ranges between -0.6 and $+7.2 \mathrm{~m}$ (average values for each location over the full suite of Earth models). This range of likely adjustments is of the same order of magnitude as the existing range of GMSL estimates for the LIG (i.e., +4 to $+10 \mathrm{~m}$ above present), and therefore cannot be ignored. We infer that considering alternate ice-sheet configurations for the PGM will cause adjustments of several metres in GIA corrections, even at far-field sites (Fig. 8; Table 6). More precise PGM ice-volume and mass-distribution reconstructions, and improved GIA models, will be needed to obtain more conclusive LIG GMSL estimates. For example, Dendy et al. (2017) highlighted the inadequacy of constructing past ice histories by replicating the same glacial cycle. They quantified the scale of the sensitivity by comparing results from a MIS 6/5 deglaciation based on a particular age model (Waelbroeck et al., 2002; Shakun et al., 2015) with a deglaciation that replicated the most recent one. This uncertainty is likely to be refined further as constraints on age models for the MIS 6 deglaciation continue to evolve (Marino et al., 2015).

Our initial assessment with hypothetical scenarios indicates a high probability that LIG GMSL estimates will need to be altered significantly. One caveat applies, namely that the inferred adjustments are partly due to the selection of sites used, given that none seems to sample the major regions of negative adjustment in Fig. 8. This suggests that these commonly used key sites for LIG sea-level study may not be the most representative sampling for determining GMSL, and that sound LIG estimates will need a denser suite of sites at which LIG RSL observations are made. Then, the same exercise performed here for 7 sites should be performed for a wider suite, to evaluate the impact of different ice-mass distributions.

\subsection{The global $\delta^{18} \mathrm{O}$ :sea-level/ice-volume relationship}

The PGM-LGM value of $\Delta z$ estimated from $\delta_{\text {sw }}$ (Elderfield et al., 2012) appears less well defined and less conclusive than that estimated from the other sea-level records (Table 2). Ice-volume/ sea-level reconstructions from seawater $\delta^{18} \mathrm{O}$ records have so far either assumed a temporally invariant relationship, or one in which ice became isotopically more negative with increasing ice volume within a glacial cycle (e.g., Duplessy et al., 2002; Waelbroeck et al., 2002; Bintanja et al., 2005; Siddall et al., 2010; de Boer et al., 2014). Potential seawater $\delta^{18} \mathrm{O}$ bias among glacial cycles due to different ice-volume to ice- $\delta^{18} \mathrm{O}$ relationships would therefore affect all ocean- $\delta{ }^{18} \mathrm{O}$-based methods, including the Red Sea and Mediterranean sea-level methods. However, the relative impact of this bias depends on the signal-to-noise ratio of each record, and specifically on the strength of the marginal-sea residence-time effect in the Red Sea and Mediterranean. Relative to open-ocean deep-sea glacialinterglacial $\delta^{18} \mathrm{O}$ gradients $(\sim 1-1.5 \%$ ), Mediterranean and Red Sea $\delta^{18} \mathrm{O}$ gradients are $2-3$ times and $5-6$ times as large, respectively. A global seawater $\delta^{18} \mathrm{O}$ bias of, for example, $\sim 0.2 \%$ would therefore have limited impact in Red Sea or Mediterranean sea-level reconstructions, but would substantially affect the open-ocean $\delta_{\text {sw }}$ method.

With this in mind, we note that global deep-sea benthic foraminiferal carbonate $\delta^{18} \mathrm{O}$ records $\left(\delta_{\mathrm{c}}\right)$ commonly have PGM and LGM values that are identical within uncertainties (Table 4). Such records represent combined ice-volume and deep-sea temperature influences, in a proportional relationship of $\sim 22 \pm 3 \mathrm{~m}^{\circ} \mathrm{C}^{-1}(1 \sigma)$ (Adkins et al., 2002; Martin et al., 2002; Sosdian and Rosenthal, 2009; Elderfield et al., 2012). Thus, our mean $\Delta \mathrm{z}$ of $21 \mathrm{~m}$ implies $\sim 1{ }^{\circ} \mathrm{C}$ lower deep-sea temperatures during the PGM than the LGM (see also Rohling et al., 2014). SW Pacific Mg/Ca-based deep-sea temperature estimates suggest $1 \pm 0.5{ }^{\circ} \mathrm{C}$ lower values during the 

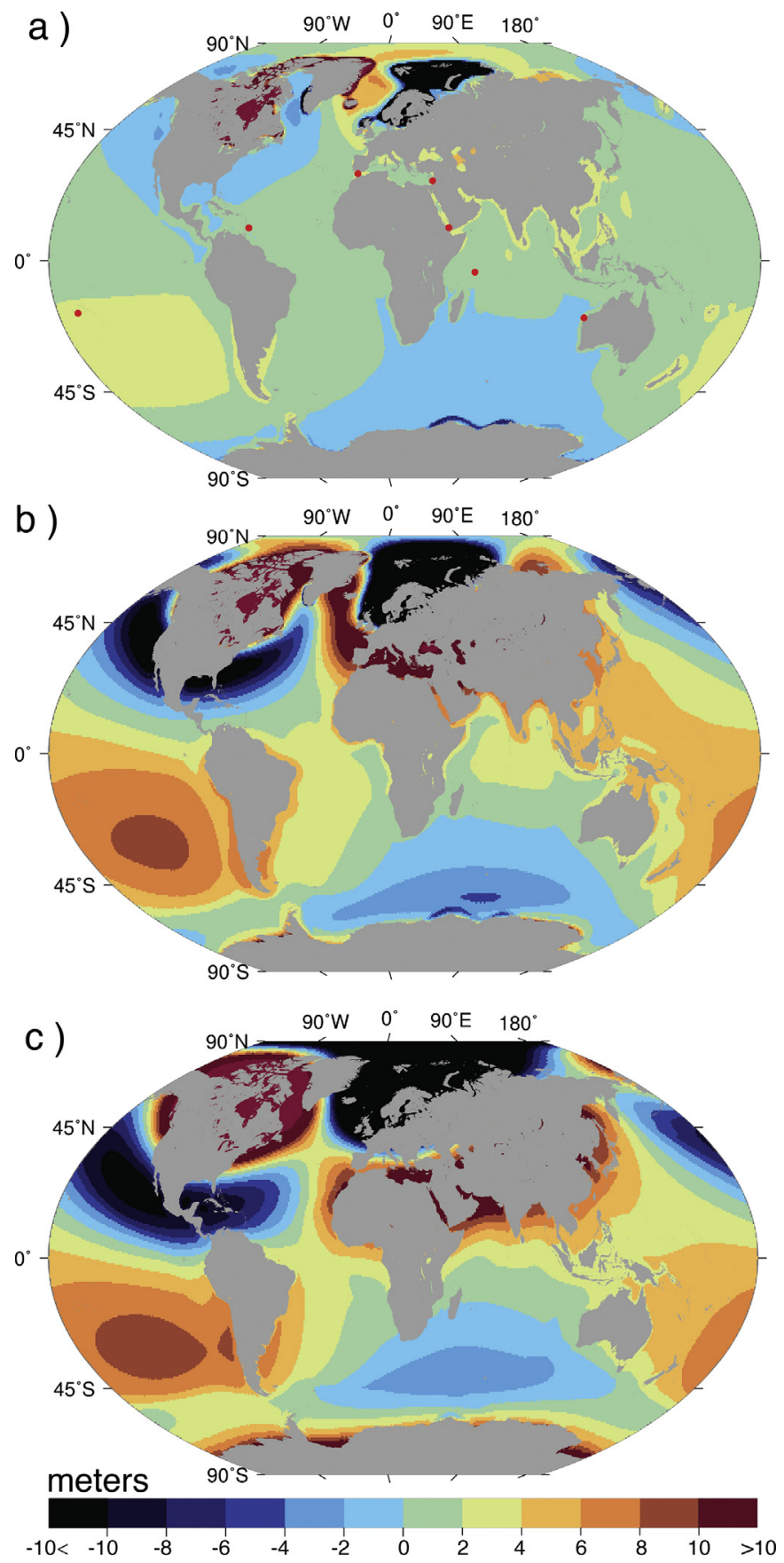

Fig. 8. Differences between peak (maximum) LIG RSL values for ice histories ICE-1 and ICE-3, for three different representative Earth models (Table 7). The analysis includes results from the entire LIG, between 116 and $130 \mathrm{ka}$. a. Using Earth model E1. b. Based on E2. c. For E3 (Table 7). Red dots in a represent key sites referenced in this study. Positive values indicate that the ICE-3 scenario generates lower peak (maximum) MIS 5e RSL values than the ICE-1 scenario.

wider PGM interval (160-140 kyr ago) than the LGM (Elderfield et al., 2012). Another $\mathrm{Mg} / \mathrm{Ca}$ study also suggests that Pacific PGM deep-sea temperatures were $\sim 1{ }^{\circ} \mathrm{C}$ lower than for the LGM (Martin et al., 2002). These anomalies fall well within the uncertainties of $\mathrm{Mg} / \mathrm{Ca}$ calibrations, which remain poorly constrained at these low temperatures, especially because near-freezing temperatures require extrapolation outside the present-day calibration window for the method (Martin et al., 2002; Elderfield et al., 2010). More importantly, it is difficult to imagine how deep-sea temperatures could have been much lower than in the LGM because (pressurecorrected) conditions are thought to have been close to freezing in much of the LGM deep sea already (Adkins et al., 2002). Deconvolution of deep Pacific $\delta_{\mathrm{c}}$ into temperature and sea-level related $\delta_{\text {sw }}$ components suggests similar deep-sea temperatures for the PGM and LGM (Siddall et al., 2010). Finally, Antarctic temperature reconstructions - from the continent adjacent to locations where abyssal ocean temperatures are acquired - indicate similar PGM and LGM temperatures (Table 4), which indirectly suggests similar deep-sea temperatures.

If PGM and LGM deep-sea temperatures were similar (within about $0.5{ }^{\circ} \mathrm{C}$ ), then a fundamental PGM-LGM offset is implied in the relationships between mean global-ocean $\delta_{\text {sw }}$ and sea level or ice volume. This might arise from: (a) ocean circulation differences among glacial cycles, filling different volumes of the deep sea with waters of different mean $\delta_{\mathrm{sw}}$ values, although such contrasts are thought to be averaged over multi-millennial periods (e.g., Siddall et al., 2010); (b) different moisture pathways feeding contrasting glacial configurations (e.g., Ullman et al., 2014; Colleoni et al., 2016), with impacts on atmospheric vapour isotopic fractionation and, hence, ice $\delta^{18} \mathrm{O}$; or (c) potential development of massive, largely floating Arctic ice shelves during certain glacials (e.g., PGM), and not during others (e.g., LGM) - these would cause negligible sea level change, but considerable mean ocean $\delta^{18} \mathrm{O}$ change (Niessen et al., 2013; Jakobsson et al., 2016). Below, we discuss these three options in turn.

Variations in $\delta_{\text {sw }}$ arise from: the waxing and waning of ice sheets (i.e., changes in global ice volumes); changes in the balance of evaporation and precipitation (e.g., Duplessy et al., 1991, 1992); changes in the balance between advection and mixing between water masses (e.g., Curry and Oppo, 1997); and changes in the processes and intensity of deep-water formation, where varying contributions of melt-water, entrained water, and brine to the newly formed deep waters may impose regional $\delta_{\text {sw }}$ anomalies. For example, pore-water $\delta_{\mathrm{sw}}$ measurements are different in the deep Pacific, and northern and southern Atlantic between the LGM and today (Adkins et al., 2002); the inferred changes suggest a large freshwater imbalance in the northern convecting regions during the LGM, with an important role for increased sea-ice formation and export. Given the great difference in Arctic sea-ice conditions that has been inferred between the PGM (less extensive and seasonally open) and LGM (extensive and severe sea-ice conditions) (Knies et al., 2000; Polyak et al., 2010; de Vernal et al., 2013; Niessen et al., 2013; Arndt et al., 2014; Jakobsson et al., 2010, 2014b; Löwemark et al., 2016), a difference in both the isotopic composition and volumetric contribution of northern-sourced deep waters might be expected between the two glacial periods. There are some hints of local $\delta_{s w}$ differences between the two glacial intervals (e.g., Skinner and Shackleton, 2005), with a shoaled hydrographic gradient separating northern- and southern-sourced deep waters and a potentially weaker North Atlantic overturning cell during the PGM. Oxygen-isotope tracer models may help to unravel varying changes in source $\delta_{\text {sw }}$ as well as different volumetric sourcecontributions to the deep sea in different locations.

Decoupling of the $\delta_{\text {sw: }}$ :ice-volume relationship could also occur if the moisture pathways of ice growth change between different glacial intervals (option $b$ above). Vapour sourced from surface waters records the initial surface-water $\delta_{s w}$ (source-water effect), so that regional variations in source $\delta_{\mathrm{sw}}$ have some initial impact on ice-sheet $\delta^{18} \mathrm{O}$. More importantly, ice $\delta^{18} \mathrm{O}$ also changes with the intensity of Rayleigh distillation, as accumulation changes from warm, low-elevation to colder, higher-elevation environments as glaciation progresses. Similarly, longer air trajectories with more Rayleigh distillation lead to accumulation of ice with lower $\delta^{18} \mathrm{O}$. As a result, each ice sheet will have a different isotopic time- 
Table 7

Summary of three representative Earth models used in Fig. 8.

\begin{tabular}{|c|c|c|}
\hline $\begin{array}{l}\text { Earth } \\
\text { Model }\end{array}$ & Parameterisations & Rationale \\
\hline E1 & $\begin{array}{l}96 \mathrm{~km} \text { thick lithosphere } \\
5 \times 10^{20} \mathrm{~Pa} \text { s upper mantle viscosity } \\
2.5 \times 10^{21} \text { Pa s lower mantle viscosity }\end{array}$ & VM2-like (Peltier, 2004). \\
\hline E2 & $\begin{array}{l}120 \mathrm{~km} \text { thick lithosphere } \\
5 \times 10^{20} \mathrm{~Pa} \text { s upper mantle viscosity } \\
1.3 \times 10^{22} \text { Pa s lower mantle viscosity }\end{array}$ & $\begin{array}{l}\text { Closest within suite of earth } \\
\text { models to a recent preferred } \\
\text { earth model for North American } \\
\text { ice history (Lambeck et al., 2017). }\end{array}$ \\
\hline E3 & $\begin{array}{l}71 \mathrm{~km} \text { thick lithosphere } \\
1.6 \times 10^{20} \text { Pa } \mathrm{s} \text { upper mantle viscosity } \\
5 \times 10^{22} \mathrm{~Pa} \text { s lower mantle viscosity }\end{array}$ & $\begin{array}{l}\text { Closest within suite of earth } \\
\text { models to recent preferred earth } \\
\text { model for the last deglaciation } \\
\text { (Lambeck et al., 2014). }\end{array}$ \\
\hline
\end{tabular}

“evolution” (e.g., Mix and Ruddiman, 1984) depending upon their volume/height and the latitudinal range over which they expand. As discussed before, the different configurations of the NAIS and EIS during the PGM, relative to the LGM, strongly suggest that their processes of glacial inception and ice-sheet growth were also different (e.g., Colleoni et al., 2011). Thus, differences in atmospheric circulation - and hence moisture supply and degree of isotopic fractionation - as induced by a lower PGM NAIS may have affected the isotopic composition of globally integrated ice volume, leading to potential misrepresentations of both amplitude and timing of the ice-volume signal (e.g., Mix and Ruddiman, 1984; Clark and Mix, 2002). So far, even the LGM isotopic compositions of various ice sheets (and their time-evolution) remain poorly constrained (e.g., Duplessy et al., 2002; Ferguson and Jasechko, 2015), and even less information is available for the PGM. Again, isotope-enabled models may help to characterise the potential impact of different moisture-transport pathways and fractionation effects in the $\delta_{\mathrm{sw}}$ :ice-volume difference between the PGM and LGM.

Contributions from options ( $a$ ) and (b), outlined above, cannot be excluded. But option (c), which involves potential development of massive, largely floating Arctic ice shelves during the PGM and not during the LGM, may be particularly important given the large size and longstanding character of the PGM $\delta_{c}$ :sea-level discrepancy relative to the LGM. Evidence of past floating ice shelves can be elusive or equivocal because, by their nature, they preserve few traces. However, ice-grounding features (e.g., parallel streamlined submarine landforms and ploughmarks) may be preserved in seafloor sediments, and their occurrence on bathymetric highs, in conjunction with regions devoid of glaciogenic seabed disturbance, has been used to suggest evidence of past floating ice (e.g., Polyak et al., 2001; Jakobsson et al., 2008). In the Arctic, erosional features have been found at depths of $\sim 1 \mathrm{~km}$ on the Lomonosov Ridge, Chukchi Borderlands, Yermak Plateau, East Siberian Margin, Baffin Bay, and Hovgaard Ridge (Fram Strait) (e.g., Polyak et al., 2001; Kuijpers et al., 2007; Dowdeswell et al., 2010; Gebhardt et al., 2011; Niessen et al., 2013; Arndt et al., 2014), while other portions of the Lomonosov and Mendeleev Ridges are largely devoid of glaciogenic features, which may suggest ice-free conditions (Jakobsson et al., 2010). Bathymetric highs in the Arctic may have acted as pinning points, allowing ice-rise formation that stabilised and facilitated ice-shelf thickening (Vogt et al., 1994; Grosswald and Hughes, 1999; Jakobsson et al., 2016).

(Largely) floating Arctic ice shelves during glacial intervals were proposed in the 1970s and 1980s (Mercer, 1970; Hughes et al., 1977; Broecker, 1975; Grosswald, 1980; Denton and Hughes, 1981; Williams et al., 1981; Chappell and Shackleton, 1986), but then were overlooked due to difficulties in obtaining data from the region and a lack of direct evidence for such shelves during the LGM (for an overview, see Jakobsson et al., 2016). Recent geophysical mapping in the Arctic, however, has led to a re-evaluation of large floating Arctic ice shelves during the Pleistocene. Various mechanisms have been proposed to account for the mapped submarine features, including the drifting of ice-shelf remnants or mega-bergs trapped in multi-year sea ice, or a transient surge or brief grounding of a floating ice shelf (Polyak et al., 2001, 2009; Engels et al., 2008; Dowdeswell et al., 2010; O'Regan et al., 2010; Gebhardt et al., 2011; Niessen et al., 2013; Dove et al., 2014). Age control for many of the features remains enigmatic, often relying on stratigraphic correlation and biostratigraphy; for example, identification of diagnostic MIS 5e nannofossils gives a likely, or minimum, MIS 6 age estimate for features on Morris Jesup Rise, Lomonosov Ridge, Yermak Plateau, Hovgaard Ridge, Mendeleev Ridge, and Arlis Plateau (Jakobsson, 1999; Polyak et al., 2001; Matthiessen and Knies, 2001; Kristoffersen et al., 2004; Spielhagen et al., 2004; Jakobsson et al., 2008, 2010, 2016; Arndt et al., 2014; Löwemark et al., 2016). Debate continues not only about the age of the submarine features (e.g., Flower, 1997; Niessen et al., 2013), but also about the scale of any ice shelves, from Arcticwide as proposed by Hughes et al. (1977) and more recently by Jakobsson et al. (2016), to (much) more limited extents (Engels et al., 2008; Jakobsson et al., 2010; Niessen et al., 2013; Stein et al., 2017).

The potential presence of an Arctic ice shelf raises questions about regional oceanography. Seasonally open waters (leads in the ice) are thought to have been continually present in portions of the Arctic throughout the last two glacial-interglacial cycles, albeit to a lesser degree during glacial periods (Hebbeln and Wefer, 1997; Lloyd et al., 1996; Spielhagen et al., 2004; Knies and Spielhagen, 2016). Such open waters may have provided an important moisture source for ice growth in Eurasia (Spielhagen et al., 2004). In order to reconcile the presence of a large ice shelf with continued warm-water advection into the Arctic (Lloyd et al., 1996; Knies et al., 2000; Spielhagen et al., 2004), deepening of the cold halocline and advection of Atlantic waters at greater depth than present have been proposed (e.g., Jakobsson et al., 2010; Cronin et al., 2012). The Lomonosov Ridge may have acted as a topographic barrier to Atlantic water circulation in the Amerasian Basin, possibly promoting ice-shelf growth in this region (Jakobsson et al., 2010). Extensive MIS 6 ice-shelf/shelves covering the central Arctic (e.g., Hughes et al., 1977; Jakobsson et al., 2016) suggest partial contact with warmer Atlantic waters in cavities under the ice shelf, analogous to modern Antarctic ice shelves (e.g., Kirschner et al., 2013), with a potential for continued exchange of warmer waters across Lomonosov Ridge below the grounded ice shelf. Alternatively, Kristoffersen et al. (2004) suggested that advection of warmer Atlantic waters to Lomonosov Ridge during MIS 6 was associated with surges or collapses of Saalian ice-sheets, which may have facilitated northward drift of deep-draft icebergs across Lomonosov 
Ridge from their discharge areas in the northern Barents-Kara region.

Overall, the above discussion indicates that evidence for grounded ice in the Arctic is unequivocal, and some seabed features have been attributed to ice-shelf processes (e.g., Polyak et al., 2001; Jakobsson et al., 2010, 2016; Niessen et al., 2013). However, the age and extent of any Arctic ice-shelves remain elusive, and the existence of Arctic (or even pan-Arctic) ice shelves remains an open and ongoing field of research. We investigate what a sea-waterdisplacing Arctic ice mass/shelf might imply for the $\delta_{\text {sw: }}$ ice-volume relationship for the PGM. First, assuming a modern Arctic Ocean area at about $800 \mathrm{~m}$ depth $\left(5.3 \times 10^{12} \mathrm{~m}^{2}\right)$ and a world-ocean surface area of $362 \times 10^{12} \mathrm{~m}^{2}$, our inferred sea-level discrepancy between the LGM and PGM ( $21 \mathrm{~m}_{\mathrm{SLE}} \pm 14 \mathrm{~m}$ at 95\% probability) would produce an ice shelf of the correct thickness $(\sim 1.4 \pm 0.9 \mathrm{~km})$ to account for the observed glacial erosional features in the Arctic. Massive Arctic ice shelves that consist of continental ice with low $\delta^{18} \mathrm{O}$ values - largely floating, but also as water-displacing grounded ice - would alter the relationship between $\delta_{\text {sw }}$ and sea level (and hence, land-based/grounded ice volume) relative to the LGM, even if the relationship between $\delta_{\text {sw }}$ and total (landbased + floating/water-displacing) global ice volume remained constant. It has been estimated that PGM Arctic ice shelves may have caused a $0.14 \pm 0.03 \%$ increase in global $\delta_{\mathrm{sw}}$ (and $\delta_{\mathrm{c}}$ ), with only a $0.4 \mathrm{~m}$ sea-level impact (Jakobsson et al., 2016). If we use the LGM land-ice-based ratio of $0.009 \pm 0.001 \mathrm{~m}$ per $\%$ o $(1 \sigma)$ (Adkins et al., 2002; Schrag et al., 2002), then such a $\delta_{\text {sw }}$ anomaly would equate to $16 \pm 10 \mathrm{~m}$ of sea-level change, at $95 \%$ probability. This again suggests that our observed $\Delta z=21 \pm 14 \mathrm{~m}$ (with indistinguishable deep-sea $\delta^{18} \mathrm{O}$ ) may be largely accounted for by the presence of massive PGM Arctic ice shelves, and by their absence during the LGM. Contribution of both land-based and floating/ water-displacing ice volume to PGM $\delta_{\mathrm{sw}}$ (and $\delta_{\mathrm{c}}$ ) results in a smaller sea-level drop, while contributions of only land-based ice to LGM $\delta_{\mathrm{sw}}\left(\right.$ and $\delta_{\mathrm{c}}$ ) gives a larger sea-level drop.

\section{Conclusions}

We provide independent evidence that continental ice volumes on North America (NAIS) and Eurasia (EIS) differed between the PGM and the LGM. During the PGM, the EIS likely reached 33-53

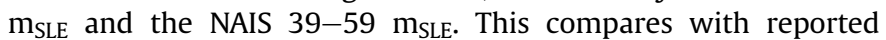
(Table 1) LGM values of 14-29 and 51-88 $\mathrm{m}_{\mathrm{SLE}}$ for the EIS and NAIS, respectively. Our results provide independent support for the inference that Arctic-wide ice shelves existed during the PGM and not the LGM, with a previously estimated volume of $\sim 16 \mathrm{~m}_{\mathrm{SLE}}$ (actual sea-level impact was negligible because the ice was displacing seawater). The existence of different ice-sheet configurations between Eurasia, North America, and the Arctic implies that complex ice-sheet nucleation processes and growth processes can lead to different glacial modes and that one glacial cycle cannot be used as an analogue for another. Among glacial cycles, we infer distinctly different relationships between mean global seawater $\delta^{18} \mathrm{O}$ and global continental ice volume/sea level, and/or between deep-sea and Antarctic temperatures. New research using PGM and LGM glaciation 'modes' may improve understanding of the controls on ice-mass distribution and on Arctic ice-shelf development during glacial inception. Comparison of the last two glacial cycles with older glacial cycles is needed to test if there are only two fundamental modes, or many. Finally, we infer that sea-level studies for the last interglacial - which was warmer and had higher sea levels than modern pre-industrial times - may contain considerable bias from erroneous assumptions about PGM ice volume and distribution. Depending on the global location of a given site of relative sealevel reconstruction, the adjustment to GIA correction as inferred here for different ice configurations can be several metres in a positive or negative direction. Results across three representative Earth models suggest that - if a global assessment were made based on the sites of LIG sea-level reconstruction considered here LIG global mean sea level would be estimated $\geq 2 \mathrm{~m}$ higher than conventional estimates (from the same sites) with GIA correction based on an LGM-like PGM ice distribution. This requires validation by more complete assessments because it has ramifications for studies of potential ice-reduction processes that are being used to evaluate sea-level risk in our warming future.

\section{Acknowledgements}

This work was supported by Australian Laureate Fellowship FL120100050 (E.J.R.), UK Natural Environment Research Council (NERC) consortium project iGlass (NE/1009906/1 and NE/1008365/ 1; E.J.R., F.D.H., F.H.W., A.P.R.), Australian Research Council DP1094001 (J.M.W.), and Japan Society for the Promotion of Science KAKENHI projects JP26247085, and JP15KK0151 (Y.Y.). F.H.W. acknowledges constructive discussions with Mark Tamisiea regarding the GIA modelling and results. We thank Tony Purcell (ANU) for providing LGM and PGM ice-volume estimates reported in Table 1, using the model detailed in Lambeck et al. (2006, 2010, 2017). Our study uses two databases, one on the coral sea-level markers (published in 2016), and the other on glaciomorphological evidence (this study). Both are available via http://www.highstand.org/ erohling/ejrhome.htm, where they will be regularly updated. The glaciomorphological dataset in a fixed form precisely as used in this study is also archived at https://doi.org/10.6084/m9.figshare. 5131963.v1.

\section{Appendix I}

Appendix 1a. Details and references for the new glaciogeomorphological database

The database contains locations and dates of PGM glaciogenic sediments, or other dated deposits (not necessarily of glacial origin) that directly over- or under-lie glacial deposits relating to the PGM. The database is available directly via the URL listed in the main-text acknowledgements (https://doi.org/10.6084/m9.figshare.5131963. v1). The field descriptors for the database are given in the table below.

\begin{tabular}{|c|c|c|}
\hline Column & Identifier & Description \\
\hline A & Identifier & Numerical database entry number \\
\hline $\mathrm{B}$ & Location & Geographic location \\
\hline $\mathrm{C}$ & Site & Local site name \\
\hline $\mathrm{D}$ & Latitude & Decimal latitude \\
\hline $\mathrm{E}$ & Longitude & Decimal longitude \\
\hline $\mathrm{F}$ & $\begin{array}{l}\text { Lat/Long } \\
\text { estimated? }\end{array}$ & $\begin{array}{l}\text { Whether the latitude or longitude of the site is } \\
\text { estimated }\end{array}$ \\
\hline G & $\begin{array}{l}\text { Unit } \\
\text { designation }\end{array}$ & $\begin{array}{l}\text { Stratigraphic unit (as determined by the original } \\
\text { authors), e.g., Saalian, Warthe etc. }\end{array}$ \\
\hline $\mathrm{H}$ & Feature & Type of deposit \\
\hline I & Reference & Publication source \\
\hline $\mathrm{J}$ & $\begin{array}{l}\text { Dating } \\
\text { method }\end{array}$ & Dating method \\
\hline $\mathrm{K}$ & $\begin{array}{l}\text { Material } \\
\text { dated }\end{array}$ & The type of material dated \\
\hline $\mathrm{L}$ & $\begin{array}{l}\text { Reported age } \\
\text { (ka) }\end{array}$ & Calculated age as originally reported \\
\hline M & $\begin{array}{l}\text { Age } \\
\text { uncertainty }\end{array}$ & Age uncertainty as originally reported \\
\hline $\mathrm{N}$ & Interpretation & $\begin{array}{l}\text { Palaeo-environmental interpretation of the deposit (by } \\
\text { the original authors) }\end{array}$ \\
\hline
\end{tabular}



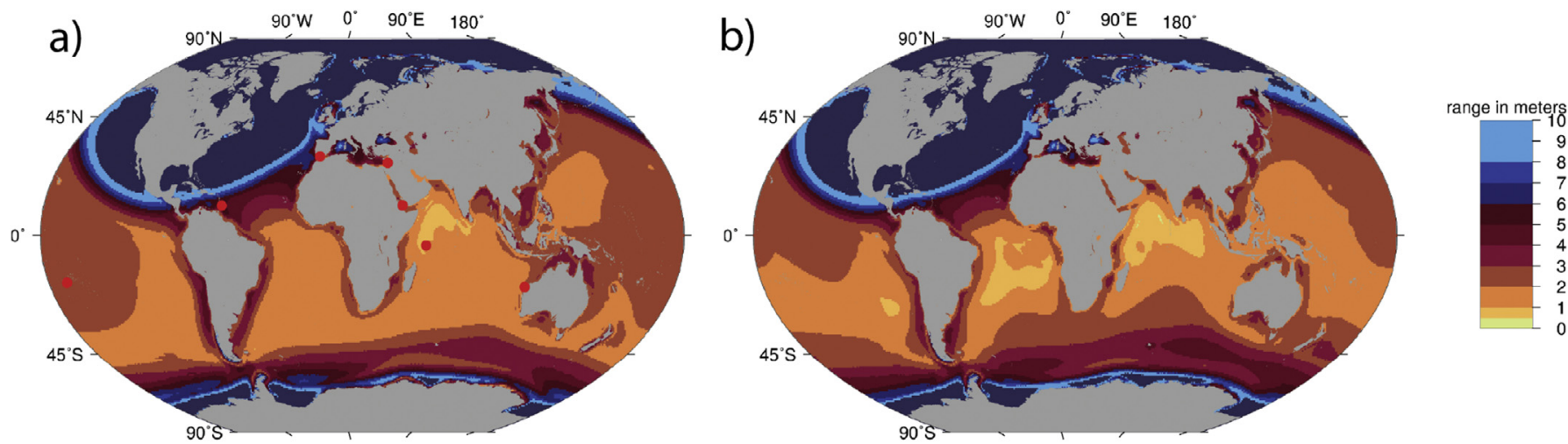

C)

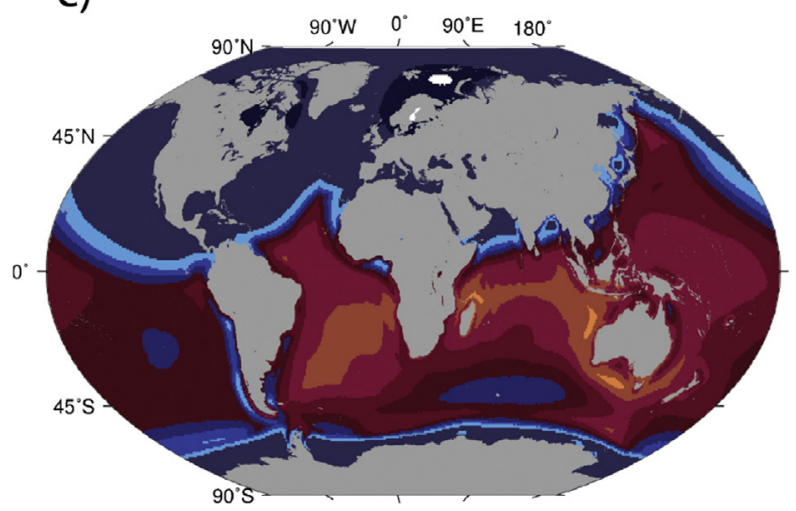

d)

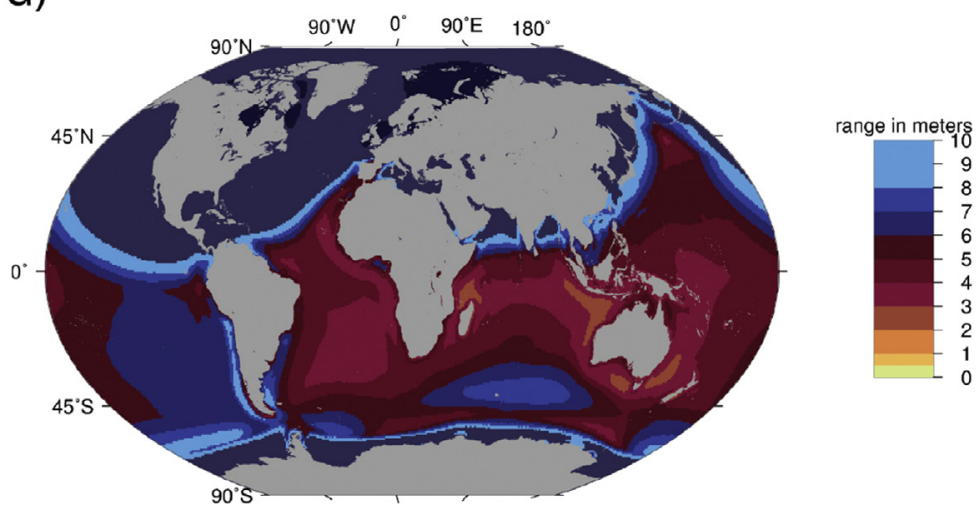

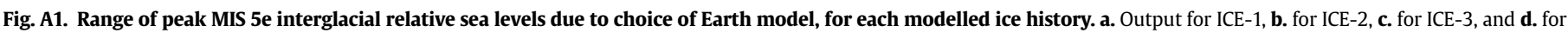

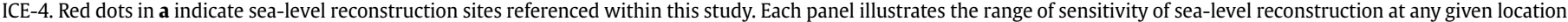

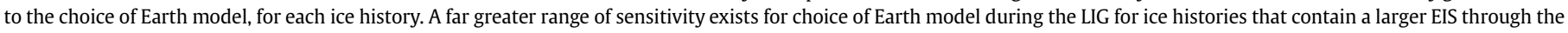
PGM (ICE-3 and ICE-4) than for ICE histories that infer an LGM-like PGM (ICE-1 and ICE-2).

\section{References}

Abe-Ouchi, A., Segawa, T., Saito, F., 2007. Climatic conditions for modelling the Northern Hemisphere ice sheets throughout the ice age cycle. Clim. Past. 3, 423-438.

Abe-Ouchi, A., Saito, F., Kawamura, K., Raymo, M.E., Okuno, J.I., Takahashi, K., Blatter, H., 2013. Insolation-driven 100,000-year glacial cycles and hysteresis of ice-sheet volume. Nature 500, 190-193.

Abe-Ouchi, A., Saito, F., Kageyama, M., Braconnot, P., Harrison, S.P., Lambeck, K., Otto-Bliesner, B., Peltier, W.R., Tarasov, L., Peterschmitt, J.Y., Takahashi, K., 2015 Ice-sheet configuration in the CMIP5/PMIP3 last glacial maximum experiments. Geosci. Model Dev. 8, 3621-3637.

Adkins, J.F., McIntyre, K., Schrag, D.P., 2002. The salinity, temperature, and $\delta^{18} \mathrm{O}$ of the glacial deep ocean. Science 298, 1769-1773.

Ahn, J., Brook, E.J., 2014. Siple Dome ice reveals two modes of millennial $\mathrm{CO}_{2}$ change during the last ice age. Nat. Commun. 5, 3732. https://doi.org/10.1038/ ncomms4723.

Aitken, M.J., 1998. An Introduction to Optical Dating. The Dating of Quaternary Sediments by the Use of Photon-stimulated Luminescence. Oxford University Press, Oxford, 267 pp.

Argus, D.F., Peltier, W.R., Drummond, R., Moore, A.W., 2014. The Antarctica component of postglacial rebound model ICE-6G_C (VM5a) based upon GPS positioning, exposure age dating of ice thicknesses, and relative sea level histories. Geophys. J. Int. 198, 537-563.

Arndt, J.E., Niessen, F., Jokat, W., Dorschel, B., 2014. Deep water paleo-iceberg scouring on top of Hovgaard Ridge-Arctic Ocean. Geophys. Res. Lett. 41, 5068-5074.

Arz, H.W., Pätzold, J., Müller, P.J., Moammar, M.O., 2003. Influence of Northern Hemisphere climate and global sea level rise on the restricted Red Sea marine environment during termination I. Paleoceanography 18, 1053,. https://doi.org/ 10.1029/2002PA000864.

Arz, H.W., Lamy, F., Ganopolski, A., Nowaczyk, N., Pätzold, J., 2007. Dominant
Northern Hemisphere climate control over millennial-scale glacial sea-level variability. Quat. Sci. Rev. 26, 312-321.

Astakhov, V., 2001. The stratigraphic framework for the Upper Pleistocene of the glaciated Russian Arctic: changing paradigms. Glob. Planet. Chang. 31, 283-295.

Astakhov, V., 2011. Ice margins of Northern Russia revisited. In: Ehlers, J., Gibbard, P.L., Hughes, P.D. (Eds.), Quaternary Glaciations - Extent and Chronology: a Closer Look. Elsevier, Amsterdam, pp. 323-336. Developments in Quaternary Science 15.

Astakhov, V.I., 2013. Pleistocene glaciations of northern Russia-a modern view. Boreas 42, 1-24.

Astakhov, V., Shkatova, V., Zastrozhnov, A., Chuyko, M., 2016. Glaciomorphological map of the Russian federation. Quat. Int. 420, 4-14.

Balson, S., Jeffery, D.H., 1991. The glacial sequence of the southern North Sea. In: Ehlers, J., Gibbard, P.L., Rose, J. (Eds.), Glacial Deposits in Great Britain and Ireland. A. A. Balkema, Rotterdam, pp. 245-254.

Bar-Matthews, M., Ayalon, A., Gilmour, M., Matthews, A., Hawkesworth, C.J., 2003. Sea-land oxygen isotopic relationships from planktonic foraminifera and speleothems in the Eastern Mediterranean region and their implication for paleorainfall during interglacial intervals. Geochim. Cosmochim. Acta 67, 3181-3199.

Bar-Or, R., Erlick, C., Gildor, H., 2008. The role of dust in glacial-interglacial cycles. Quat. Sci. Rev. 27, 201-208.

Bard, E., Hamelin, B., Fairbanks, R.G. Zindler, A., 1990. Calibration of the $14 \mathrm{C}$ timescale over the past 30,000 years using mass spectrometric U-Th ages from Barbados corals. Nature 345, 405-410.

Bard, E., Hamelin, B., Arnold, M., Montaggioni, L., Cabioch, G., Faure, G., Rougerie, F., 1996. Deglacial sea-level record from Tahiti corals and the timing of global meltwater discharge. Nature 382, 241-244.

Bard, E., Hamelin, B., Delanghe-Sabatier, D., 2010. Deglacial meltwater pulse 1B and Younger Dryas sea levels revisited with boreholes at Tahiti. Science 327, 1235-1237. 
Barendregt, R.W., Duk-Rodkin, A., 2011. Chronology and extent of Late Cenozoic ice sheets in North America: a magnetostratigraphical assessment. In: Ehlers, J., Gibbard, P.L., Hughes, P.D. (Eds.), Quaternary Glaciations - Extent and Chronology: a Closer Look. Elsevier, Amsterdam, pp. 419-426. Developments in Quaternary Science 15.

Bazin, L., Landais, A., Lemieux-Dudon, B., Toyé Mahamadou Kele, H., Veres, D., Parrenin, F., Martinerie, P., Ritz, C., Capron, E., Lipenkov, V., Loutre, M.F., 2013. An optimized multi-proxy, multi-site Antarctic ice and gas orbital chronology (AICC2012): 120-800 ka. Clim. Past. 9, 1715-1731.

Bintanja, R., van de Wal, R., Oerlemans, J., 2005. Modelled atmospheric temperatures and global sea levels over the past million years. Nature 437, 125-128.

Bond, G., Lotti, R., 1995. Iceberg discharges into the North Atlantic on millennial time scales during the last glaciation. Science 267, 1005-1010.

Braun, D.D., 2011. The glaciation of Pennsylvania, USA. In: Ehlers, J., Gibbard, P.L., Hughes, P.D. (Eds.), Quaternary Glaciations - Extent and Chronology: a Closer Look. Elsevier, Amsterdam, pp. 521-529. Developments in Quaternary Science 15.

Briggs, R.D., Pollard, D., Tarasov, L., 2014. A data-constrained large ensemble analysis of Antarctic evolution since the Eemian. Quat. Sci. Rev. 103, 91-115.

Broecker, W.S., 1975. Floating glacial ice caps in the Arctic Ocean. Science 188, 1116-1118.

Buckley, M.W., Marshall, J., 2016. Observations, inferences, and mechanisms of the atlantic meridional overturning circulation: a review. Rev. Geophys. 54, 5-63.

Busschers, F.S., Weerts, H.J.T., Wallinga, J., Cleveringa, P., Kasse, C., Wolf, H.D. Cohen, K.M., 2005. Sedimentary architecture and optical dating of Middle and Late Pleistocene Rhine-Meuse deposits-fluvial response to climate change, sealevel fluctuation and glaciation. Geol. Mijnb. 84, 25-41.

Busschers, F.S., Van Balen, R.T., Cohen, K.M., Kasse, C., Weerts, H.J.T., Wallinga, J., Bunnik, F.P.M., 2008. Response of the Rhine-Meuse fluvial system to Saalian icesheet dynamics. Boreas 37, 377-398.

Calov, R., Ganopolski, A., Kubatzki, C., Claussen, M., 2009. Mechanisms and time scales of glacial inception simulated with an Earth system model of intermediate complexity. Clim. Past. 5, 245-258.

Carlson, A.E., Winsor, K., 2012. Northern Hemisphere ice-sheet responses to past climate warming. Nat. Geosci. 5, 607-613.

Carr, S.J., 2004. the North Sea basin. In: Ehlers, J., Gibbard, P.L. (Eds.), Quaternary Glaciations Extent and Chronology - Part I: Europe. Elsevier, Amsterdam, pp. 261-270. Developments in Quaternary Sciences 2.

Channell, J.E.T., Hodell, D.A., Romero, O., Hillaire-Marcel, C., de Vernal, A., Stoner, J.S., Mazaud, A., Röhl, U., 2012. A 750-kyr detrital-layer stratigraphy for the north atlantic (IODP site U1302-U1303, orphan knoll, labrador sea). Earth Planet. Sci. Lett. $317-318,218-230$.

Chappell, J., Shackleton, N., 1986. Oxygen isotopes and sea level. Nature 324, 137-140.

Clague, J.J., Ward, B., 2011. Pleistocene glaciation of british Columbia. In: Ehlers, J., Gibbard, P.L., Hughes, P.D. (Eds.), Quaternary Glaciations - Extent and Chronology: a Closer Look. Elsevier, Amsterdam, pp. 419-426. Developments in Quaternary Science 15.

Clark, P.U., Huybers, P., 2009. Interglacial and future sea level. Nature 462, 856-857.

Clark, P.U., Mix, A.C., 2002. Ice sheets and sea level of the last glacial maximum. Quat. Sci. Rev. 21, 1-7.

Clark, P.U., Pollard, D., 1998. Origin of the middle Pleistocene transition by ice sheet erosion of regolith. Paleoceanography 13, 1-9.

Clark, P.U., Tarasov, L., 2014. Closing the sea level budget at the last glacial maximum. Proc. Natl. Acad. Sci. U. S. A. 111, 15861-15862.

Clark, C.D., Evans, D.J., Khatwa, A., Bradwell, T., Jordan, C.J., Marsh, S.H., Mitchell, W.A., Bateman, M.D., 2004a. Map and GIS database of glacial landforms and features related to the last British Ice Sheet. Boreas 33, 359-375.

Clark, C.D., Gibbard, P.L., Rose, J., 2004b. Pleistocene glacial limits in England, Scotland and wales. In: Ehlers, J., Gibbard, P.L. (Eds.), Quaternary Glaciations. Extent and Chronology Part I: Europe. Elsevier, Amsterdam, pp. 47-82. Developments in Quaternary Sciences 2.

Clark, P.U., Archer, D., Pollard, D., Blum, J.D., Rial, J.A., Brovkin, V., Mix, A.C., Pisias, N.G., Roy, M., 2006. The middle Pleistocene transition: characteristics, mechanisms, and implications for long-term changes in atmospheric $\mathrm{pCO}_{2}$. Quat. Sci. Rev. 25, 3150-3184.

Clark, P.U., Dyke, A.S., Shakun, J.D., Carlson, A.E., Clark, J., Wohlfarth, B., Mitrovica, J.X., Hostetler, S.W., McCabe, A.M., 2009. The last glacial maximum. Science 325, 710-714.

Colleoni, F., Krinner, G., Jakobsson, M., Peyaud, V., Ritz, C., 2009. Influence of regional parameters on the surface mass balance of the Eurasian ice sheet during the peak Saalian (140 kya). Glob. Planet. Change 68, 132-148.

Colleoni, F., Liakka, J., Krinner, G., Jakobsson, M., Masina, S., Peyaud, V., 2011. The sensitivity of the Late Saalian (140 ka) and LGM (21 ka) Eurasian ice sheets to sea surface conditions. Clim. Dyn. 37, 531-553.

Colleoni, F., Masina, S., Cherchi, A., Iovino, D., 2014. Impact of orbital parameters and greenhouse gas on the climate of MIS 7 and MIS 5 glacial inceptions. J. Clim. 27, 8918-8933.

Colleoni, F., Wekerle, C., Näslund, J.-O., Brandefelt, J., Masina, S., 2016. Constraint on the penultimate glacial maximum Northern Hemisphere ice topography ( $\approx 140$ kyrs BP). Quat. Sci. Rev. 137, 97-112.

Cook, K.H., Held, I.M., 1988. Stationary waves of the ice age climate. J. Clim. 1, 807-819.

Cronin, T.M., Dwyer, G.S., Farmer, J., Bauch, H.A., Spielhagen, R.F., Jakobsson, M., Nilsson, J., Briggs Jr., W.M., Stepanova, A., 2012. Deep Arctic Ocean warming during the last glacial cycle. Nat. Geosci. 5, 631-634.

Curry, W.B., Oppo, D.W., 1997. Synchronous, high-frequency oscillations in tropical sea surface temperatures and North Atlantic Deep Water production during the last glacial cycle. Paleoceanography 12, 1-14.

Curry, B.B., Grimley, D.A., McKay III, E.D., 2011. In: Ehlers, J., Gibbard, P.L. Hughes, P.D. (Eds.), Quaternary Glaciations - Extent and Chronology: a Closer Look. Elsevier, Amsterdam, pp. 467-487. Developments in Quaternary Science 15.

de Boer, B., Van de Wal, R.S.W., Bintanja, R., Lourens, L.J., Tuenter, E., 2010. Cenozoic global ice-volume and temperature simulations with 1-D ice-sheet models forced by benthic $\delta^{18} \mathrm{O}$ records. Ann. Glaciol. 51, 23-33.

de Boer, B., van de Wal, R.S.W., Lourens, L.J., Bintanja, R., 2012. Transient nature of the Earth's climate and the implications for the interpretation of benthic $\delta^{18} \mathrm{O}$ records. Palaeogeogr. Palaeoclimatol. Palaeoecol. 335-336, 4-11.

de Boer, B., Lourens, L., van de Wal, R.S., 2014. Persistent 400,000-year variability of Antarctic ice volume and the carbon cycle is revealed throughout the PlioPleistocene. Nat. Commun. 5, 2999,. https://doi.org/10.1038/ncomms3999.

de Vernal, A., Gersonde, R., Goosse, H., Seidenkrantz, M.S., Wolff, E.W., 2013. Sea ice in the paleoclimate system: the challenge of reconstructing sea ice from proxies-an introduction. Quat. Sci. Rev. 79, 1-8.

DeConto, R.M., Pollard, D., 2016. Contribution of Antarctica to past and future sealevel rise. Nature 531, 591-597.

Demidov, 1998 (unpublished - see Svendsen, J.I., Astakhov, V.I., Bolshiyanov, D.Y. Demidov, I., Dowdeswell, J.A., Gataullin, V., Hjort, C., Hubberten, H.W., Larsen, E., Mangerud, J., Melles, M., Möller, P., Saarnisto, M., Siegert, M.J., 1999. Maximum extent of the eurasian ice sheets in the Barents and Kara sea region during the weichselian. Boreas 28, 234-242.

Demidov, I.N., Houmark-Nielsen, M., Kjær, K.H., Funder, S., Larsen, E., Lyså, A., Lunkka, J.P., Saarnisto, M., 2004. Valdaian glacial maxima in the Arkhangelsk district of northwestern Russia. In: Ehlers, J., Gibbard, P.L. (Eds.), Quaternary Glaciations - Extent and Chronology - Part I: Europe. Elsevier, Amsterdam, pp. 321-336. Developments in Quaternary Sciences 2.

Demidov, I.N., Houmark-Nielsen, M., Kjaer, K.H., Larsen, E., 2006. The last Scandinavian Ice Sheet in northwestern Russia: ice flow patterns and decay dynamics. Boreas 35, 425-443.

Demuro, M., Froese, D.G., Arnold, L.J., Roberts, R.G., 2012. Single-grain OSL dating of glaciofluvial quartz constrains Reid glaciation in NW Canada to MIS 6. Quat. Res. 77, 305-316.

Dendy, S., Austermann, J., Creveling, J.R., Mitrovica, J.X., 2017. Sensitivity of Last Interglacial sea-level high stands to ice sheet configuration during Marine Isotope Stage 6. Quat. Sci. Rev. 171, 234-244.

Denton, G.H., Hughes, T.J., 1981. Ch. 8. In: Denton, G.H., Hughes, T.J. (Eds.), The Last Great Ice Sheets. Wiley Interscience, pp. 437-467.

Denton, G.H., Hughes, T.J., 2002. Reconstructing the Antarctic ice sheet at the Last Glacial Maximum. Quat. Sci. Rev. 21, 193-202.

Deschamps, P., Durand, N., Bard, E., Hamelin, B., Camoin, G., Thomas, A.L., Henderson, G.M., Okuno, J., Yokoyama, Y., 2012. Ice-sheet collapse and sea-level rise at the Bolling warming 14600 years ago. Nature 483, 559-564.

Dove, D., Polyak, L., Coakley, B., 2014. Widespread, multi-source glacial erosion on the Chukchi margin, Arctic Ocean. Quat. Sci. Rev. 92, 112-122.

Dowdeswell, J.A., Jakobsson, M., Hogan, K.A., O'Regan, M., Backman, J., Evans, J., Hell, B., Löwemark, L., Marcussen, C., Noormets, R., Cofaigh, C.Ó, 2010. Highresolution geophysical observations of the Yermak Plateau and northern Svalbard margin: implications for ice-sheet grounding and deep-keeled icebergs. Quat. Sci. Rev. 29, 3518-3531.

Duk-Rodkin, A., Barendregt, R.W., Tarnocai, C., Phillips, F.M., 1996. Late tertiary to late quaternary record in the Mackenzie Mountains, Northwest Territories, Canada: stratigraphy, paleosols, paleomagnetism, and chlorine-36. Can. J. Earth Sci. 33, 875-895.

Duplessy, J.C., Labeyrie, L., Juillet-Leclerc, A., Maitre, F., Duprat, J., Sarnthein, M., 1991. Surface salinity reconstruction of the north-Atlantic ocean during the last glacial maximum. Oceanol. Acta 14, 311-324.

Duplessy, J.C., Labeyrie, L., Arnold, M., Paterne, M., Duprat, J., van Weering, T.C., 1992. Changes in surface salinity of the North Atlantic Ocean during the last deglaciation. Nature 358, 485-488.

Duplessy, J.C., Labeyrie, L., Waelbroeck, C., 2002. Constraints on the ocean oxygen isotopic enrichment between the Last Glacial Maximum and the Holocene: paleoceanographic implications. Quat. Sci. Rev. 21, 315-330.

Dutton, A., Lambeck, K., 2012. Ice volume and sea level during the last interglacial. Science 337, 216-219.

Dutton, A., Carlson, A.E., Long, A.J., Milne, G.A., Clark, P.U., DeConto, R., Horton, B.P., Rahmstorf, S., Raymo, M.E., 2015a. Sea-level rise due to polar ice-sheet mass loss during past warm periods. Science 349. https://doi.org/10.1126/ science.aaa4019.

Dutton, A., Webster, J.M., Zwartz, D., Lambeck, K., Wohlfarth, B., 2015b. Tropical tales of polar ice: evidence of last interglacial polar ice sheet retreat recorded by fossil reefs of the granitic Seychelles islands. Quat. Sci. Rev. 107, 182-196.

Dyke, A.S., Andrews, J.T., Clark, P.U., England, J.H., Miller, G.H., Shaw, J., Veillette, J.J., 2002. The Laurentide and Innuitian ice sheets during the last glacial maximum. Quat. Sci. Rev. 21, 9-31.

Ehlers, J., Gibbard, P.L., 2007. The extent and chronology of Cenozoic global glaciation. Quat. Int. 164, 6-20.

Ehlers, L., Eissmann, L., Lippstreu, L., Stephan, H.-J., Wansa, S., 2004. Pleistocene glaciations of north Germany. In: Ehlers, J., Gibbard, P.L. (Eds.), Quaternary Glaciations. Extent and Chronology Part I: Europe. Elsevier, Amsterdam, 
pp. 135-146. Developments in Quaternary Science 2.

Developments in Quaternary Science 15. In: Ehlers, J., Gibbard, P.L., Hughes, P.D. (Eds.), 2011a. Quaternary Glaciations - Extent and Chronology, a Closer Look Elsevier, Amsterdam, 1108 pp.

Ehlers, J., Grube, A., Stephan, H.J., Wansa, S., 2011b. Pleistocene glaciations of North Germany - new results. In: Ehlers, J., Gibbard, P.L., Hughes, P.D. (Eds.), Quaternary Glaciations - Extent and Chronology: a Closer Look. Elsevier, Amsterdam, pp. 149-162. Developments in Quaternary Science 15.

Elderfield, H., Greaves, M., Barker, S., Hall, I.R., Tripati, A., Ferretti, P., Crowhurst, S. Booth, L., Daunt, C., 2010. A record of bottom water temperature and seawater $\delta^{18} \mathrm{O}$ for the Southern Ocean over the past $440 \mathrm{kyr}$ based on $\mathrm{Mg} / \mathrm{Ca}$ of benthic foraminiferal Uvigerina spp. Quat. Sci. Rev. 29, 160-169.

Elderfield, H., Ferretti, P., Greaves, M., Crowhurst, S., McCave, I.N., Hodell, D. Piotrowski, A.M., 2012. Evolution of ocean temperature and ice volume through the Mid-Pleistocene Climate Transition. Science 337, 704-709.

Engels, J.L., Edwards, M.H., Polyak, L., Johnson, P.D., 2008. Seafloor evidence for ice shelf flow across the Alaska-Beaufort margin of the Arctic Ocean. Earth Surf. Proc. Landf. 33, 1047-1063.

Fabel, D., Harbor, J., 1999. The use of in-situ produced cosmogenic radionuclides in glaciology and glacial geomorphology. Ann. Glaciol. 28, 103-110.

Fairbanks, R.G., 1989. A 17,000-year glacio-eustatic sea level record: influence of glacial melting rates on the Younger Dryas event and deep-ocean circulation. Nature 342, 637-642.

Fairbanks, R.G., Mortlock, R.A., Chiu, T.C., Cao, L., Kaplan, A., Guilderson, T.P. Fairbanks, T.W., Bloom, A.L., Grootes, P.M., Nadeau, M.J., 2005. Radiocarbon calibration curve spanning 0 to 50,000 years BP based on paired ${ }^{230} \mathrm{Th} /{ }^{234} \mathrm{U} /{ }^{238} \mathrm{U}$ and ${ }^{14} \mathrm{C}$ dates on pristine corals. Quat. Sci. Rev. $24,1781-1796$.

Fenton, M., Geiselhart, S., Rohling, E.J., Hemleben, C., 2000. Aplanktonic zones in the red sea. Mar. Micropal 40, 277-294.

Ferguson, G., Jasechko, S., 2015. The isotopic composition of the Laurentide Ice Sheet and fossil groundwater. Geophys. Res. Lett. 42, 4856-4861.

Flower, B.P., 1997. Overconsolidated section on the Yermak Plateau, Arctic Ocean: ice sheet grounding prior to ca. $660 \mathrm{ka}$ ? Geology 25, 147-150.

Friedrich, T., Timmermann, A., Tigchelaar, M., Timm, O.E., Ganopolski, A., 2016 Nonlinear climate sensitivity and its implications for future greenhouse warming. Sci. Adv. 2, e1501923,. https://doi.org/10.1126/sciadv.1501923.

Fugitt, F.L., Spahr, P.N., Pavey, R.R., Aden, D.J., Jones, M., Angle, M.P., 2016. Surfical Geology of the Hillsboro 30 X 60-minute Quadrangle in Ohio. Ohio Department of Natural Resources, Columbus. Division of Geological Survey Map SG-2-HIL, scale $1: 100,000$.

Gallimore, R.G., Kutzbach, J.E., 1996. Role of orbitally induced changes in tundra area in the onset of glaciation. Nature 381, 503-505.

Ganopolski, A., Calov, R., 2011. The role of orbital forcing, carbon dioxide and regolith in 100 kyr glacial cycles. Clim. Past. 7, 1415-1425.

Gaunt, G.D., Fletcher, T.P., Wood, C.J., 1992. Geology of the country around kingston upon hull and brigg. Brit. Geol. Surv. Mem. 172. HMSO, London.

Gebhardt, A.C., Jokat, W., Niessen, F., Matthießen, J., Geissler, W.H., Schenke, H.W., 2011. Ice sheet grounding and iceberg plow marks on the northern and centra Yermak Plateau revealed by geophysical data. Quat. Sci. Rev. 30, 1726-1738.

Gemmell, A.M.D., 1988. Thermoluminescence dating of glacially transported sediments: some considerations. Quat. Sci. Rev. 7, 277-285.

Gey, V., Saarnisto, M., Lunkka, J.P., Demidov, I., 2001. Mikulino and Valdai palaeoenvironments in the Vologda area, NW Russia. Glob. Planet. Change 31, $347-366$.

Gey, V.P., Kozlov, V.V., Malakhovsky, D.B., 2004. On the age and extent of the maximum Late Pleistocene ice advance along the Baltic-Caspian watershed. In: Ehlers, J., Gibbard, P.L. (Eds.), Quaternary Glaciations Extent and Chronology Part I: Europe. Elsevier, Amsterdam, pp. 355-358. Developments in Quaternary Sciences 2.

Gibbard, P.L., Clark, C.D., 2011. Pleistocene glaciation limits in great britain. In: Ehlers, J., Gibbard, P.L., Hughes, P.D. (Eds.), Quaternary Glaciations - Extent and Chronology: a Closer Look. Elsevier, Amsterdam, pp. 75-94. Developments in Quaternary Science 15

Gibbard, P.L., Cohen, K.M., 2008. Global chronostratigraphical correlation table for the last 2.7 million years. Episodes 31, 243-247.

Gibbard, P.L., West, R.G., Andrew, R., Pettit, M., 1992. The margin of a middle Pleistocene ice advance at Tottenhill, Norfolk, England. Geol. Mag. 129, 59-76.

Gibbard, P.L., Pasanen, A.H., West, R.G., Lunkka, J.P., Boreham, S., Cohen, K., Rolfe, C., 2009. Late middle Pleistocene glaciation in east Anglia, England. Boreas 38, $504-528$.

Glen, J.W., 1958. The flow law of ice: a discussion of the assumptions made in glacier theory, their experimental foundations and consequences. IASH Publ. 47, $171-183$.

Gosse, J.C., Phillips, F.M., 2001. Terrestrial in situ cosmogenic nuclides: theory and application. Quat. Sci. Rev. 20, 1475-1560.

Grant, K.M., Rohling, E.J., Bar-Matthews, M., Ayalon, A., Medina-Elizalde, M., Ramsey, C.B., Satow, C., Roberts, A.P., 2012. Rapid coupling between ice volume and polar temperature over the past $150 \mathrm{kyr}$. Nature 491, 744-747.

Grant, K.M., Rohling, E.J., Ramsey, C.B., Cheng, H., Edwards, R.L., Florindo, F, Heslop, D., Marra, F., Roberts, A.P., Tamisiea, M.E., Williams, F., 2014. Sea-level variability over five glacial cycles. Nat. Commun. 5, 5076.

Grosswald, M.G., 1980. Late Weichselian ice sheets of northern Eurasia. Quat. Res $13,1-32$

Grosswald, M.G., Hughes, T.J., 1999. The case for an ice shelf in the Pleistocene Arctic Ocean 1. Polar Geogr. 23, 23-54.
Guobyte, R., Satkunas, J., 2011. Pleistocene glaciations in Lithuania. In: Ehlers, J., Gibbard, P.L., Hughes, P.D. (Eds.), Quaternary Glaciations - Extent and Chronology: a Closer Look. Elsevier, Amsterdam, pp. 231-246. Developments in Quaternary Science 15.

Gurski, B.N., Levkov, E.A., Karabanov, A.K., Bessarab, D.A., 1990. New data about glaciations limits within the Belarus territory. Dokl. Akad. Nauk. Belarusi 34, 345-348 (in Russian).

Hansen, J., Sato, M., Kharecha, P., Russell, G., Lea, D.W., Siddall, M., 2007. Climate change and trace gases. Phil. Trans. R. Soc. Lond. A 365, 1925-1954.

Hansen, J., Sato, M., Kharecha, P., Beerling, D., Berner, R., Masson-Delmotte, V., Pagani, M., Raymo, M., Royer, D.L., Zachos, J.C., 2008. Target atmospheric $\mathrm{CO}_{2}$ : where should humanity aim? Open Atmos. Sci. J. 2, 217-231.

Hansen, J., Sato, M., Russell, G., Kharecha, P., 2013. Climate sensitivity, sea level, and atmospheric carbon dioxide. Phil. Trans. R. Soc. A 371, 20120294. https:// doi.org/10.1098/rsta.2012.0294.

Hansen, J., Sato, M., Kharecha, P., von Schuckmann, K., Beerling, D.J., Cao, J., Marcott, S., Masson-Delmotte, V., Prather, M.J., Rohling, E.J., Shakun, J., Smith, P., Lacis, A., Russell, G., Ruedy, R., 2017. Young people's burden: requirement of negative $\mathrm{CO}_{2}$ emissions. Earth Syst. Dyn. 8, 577-616.

Harris, S.A., 2005. Thermal history of the Arctic Ocean environs adjacent to North America during the last $3.5 \mathrm{Ma}$ and a possible mechanism for the cause of the cold events (major glaciations and permafrost events). Prog. Phys. Geogr. 29, $218-237$.

Hatfield, R.G., Reyes, A.V., Stoner, J.S., Carlson, A.E., Beard, B.L., Winsor, K., Welke, B., 2016. Interglacial responses of the southern Greenland ice sheet over the last 430,000 years determined using particle-size specific magnetic and isotopic tracers. Earth Planet. Sci. Lett. 454, 225-236.

Hebbeln, D., Wefer, G., 1997. Late quaternary paleoceanography in the Fram Strait. Paleoceanography 12, 65-78.

Hemming, S.R., 2004. Heinrich events: massive late Pleistocene detritus layers of the North Atlantic and their global climate imprint. Rev. Geophys 42, RG1005. https://doi.org/10.1029/2003RG000128.

Hennekam, R., 2015. High-frequency climate variability in the late Quaternary eastern Mediterranean - associations of Nile discharge and basin overturning circulation dynamics. Utrecht Stud. Earth Sci. 78, 160 pp., ISBN 978-90-6266$390-3$.

Hibbert, F.D., Rohling, E.J., Dutton, A., Williams, F.H., Chutcharavan, P.M., Zhao, C., Tamisiea, M.E., 2016. Corals as indicators of past sea-level change: a global repository of U-series dated benchmarks. Quat. Sci. Rev. 145, 1-56.

Hoffman, J.S., Clark, P.U., Parnell, A.C., He, F., 2017. Regional and global sea-surface temperatures during the last interglaciation. Science 355, 276-279.

Houmark-Nielsen, M., 2011. Pleistocene glaciations in Denmark: a closer look at chronology, ice dynamics and landforms. In: Ehlers, J., Gibbard, P.L., Hughes, P.D. (Eds.), Quaternary Glaciations - Extent and Chronology: a Closer Look. Elsevier, Amsterdam, pp. 47-58. Developments in Quaternary Science 15.

Hughes, T.J., Denton, G.H., Grosswald, M.G., 1977. Was there a late-Würm Arctic ice sheet? Nature 266, 596-602.

Hughes, P.D., Gibbard, P.L., Ehlers, J., 2013. Timing of glaciation during the last glacial cycle: evaluating the concept of a global 'Last Glacial Maximum' (LGM). EarthSci. Rev. 125, 171-198.

Huybers, P., 2006. Early Pleistocene glacial cycles and the integrated summer insolation forcing. Science 313, 508-511.

Huybrechts, P., 2002. Sea-level changes at the LGM from ice-dynamic reconstructions of the Greenland and Antarctic ice sheets during the glacial cycles. Quat. Sci. Rev. 21, 203-231.

Imbrie, J., Hays, J.D., Martinson, D.G., McIntyre, A., Mix, A.C., Morley, J.J., Pisias, N.G., Prell, W.L., Shackleton, N.J., 1984. The orbital theory of Pleistocene climate: support from a revised chronology of the marine $\delta^{18} \mathrm{O}$ record. In: Berger, A. (Ed.), Milankovitch and Climate, Part I. Springer, New York, pp. 269-305.

Imbrie, J., Berger, A., Boyle, E.A., Clemens, S.C., Duffy, A., Howard, W.R., Kukla, G., Kutzbach, J., Martinson, D.G., McIntyre, A., Mix, A.C., Molfino, B., Morley, J.J. Peterson, L.C. Pisias, N.G., Prell, W.L. Raymo, M.E., Shackleton, N.J., Toggweiler, J.R., 1993. On the structure and origin of major glaciation cycles. 2, the 100,000-year cycle. Paleoceanography 8, 699-735.

Israelson, C., Wohlfarth, B., 1999. Timing of the last-interglacial high sea level on the Seychelles Islands, Indian Ocean. Quat. Res. 51, 306-316.

Ivins, E.R., James, T.S., 2005. Antarctic glacial isostatic adjustment: a new assessment. Antarct. Sci. 17, 541-553.

Jackson, L., Ward, B., Duk-Rodkin, A., Hughes, O., 1991. The last Cordilleran ice sheet in southern Yukon Territory. Géogr. Phys. Quat. 45, 341-354.

Jackson, L.E., Andriashek, L.D., Phillips, F.M., 2011. Limits of successive Middle and Late Pleistocene continental ice sheets, interior plains of southern and central Alberta and adjacent areas. In: Ehlers, J., Gibbard, P.L., Hughes, P.D. (Eds.), Quaternary Glaciations - Extent and Chronology: a Closer Look. Elsevier, Amsterdam, pp. 575-590. Developments in Quaternary Science 15.

Jakobsson, M., 1999. First high-resolution CHIRP sonar profiles from the central Arctic Ocean reveal erosion of Lomonosov Ridge sediments. Mar. Geol. 158, $111-123$.

Jakobsson, M., Polyak, L., Edwards, M., Kleman, J., Coakley, B., 2008. Glacial geomorphology of the central Arctic Ocean: the Chukchi borderland and the Lomonosov Ridge. Earth Surf. Proc. Landf. 33, 526-545.

Jakobsson, M., Nilsson, J., O'Regan, M., Backman, J., Löwemark, L., Dowdeswell, J.A., Mayer, L., Polyak, L., Colleoni, F., Anderson, L.G., Björk, G., 2010. An Arctic Ocean ice shelf during MIS 6 constrained by new geophysical and geological data. Quat. Sci. Rev. 29, 3505-3517. 
Jakobsson, M., Andreassen, K., Bjarnadóttir, L.R., Dove, D., Dowdeswell, J.A., England, J.H., Funder, S., Hogan, K., Ingólfsson, Ó., Jennings, A., Larsen, N.K., 2014a. Arctic Ocean glacial history. Quat. Sci. Rev. 92, 40-67.

Jakobsson, M., Ingólfsson, Ó., Long, A.J., Spielhagen, R.F., 2014b. The dynamic Arctic. Quat. Sci. Rev. 92, 1-8.

Jakobsson, M., Nilsson, J., Anderson, L., Backman, J., Björk, G., Cronin, T.M., Kirchner, N., Koshurnikov, A., Mayer, L., Noormets, R., O'Regan, M., 2016. Evidence for an ice shelf covering the central Arctic Ocean during the penultimate glaciation. Nat. Commun. 7, 10365.

Kageyama, M., Valdes, P.J., 2000. Impact of the North American ice-sheet orography on the Last Glacial Maximum eddies and snowfall. Geophys. Res. Lett. 27, 1515-1518.

Kageyama, M., Valdes, P.J., Ramstein, G., Hewitt, C., Wyputta, U., 1999. Northern Hemisphere storm tracks in present day and last glacial maximum climate simulations: a comparison of the European PMIP models. J. Clim. 12, 742-760.

Karabanov, A.K., Matveyev, A.V., 2011. The Pleistocene glaciations in Belarus. In: Ehlers, J., Gibbard, P.L., Hughes, P.D. (Eds.), Quaternary Glaciations - Extent and Chronology: a Closer Look. Elsevier, Amsterdam, pp. 29-35. Developments in Quaternary Science 15.

Kendall, R.A., Mitrovica, J.X., Milne, G.A., 2005. On post-glacial sea level - II. Numerical formulation and comparative results on spherically symmetric models. Geophys. J. Int. 161, 679-706.

Kirschner, N., Furrer, R., Jakobsson, M., Zwally, H.J., Robbins, J.W., 2013. Statistical modeling of a former Arctic Ocean ice shelf complex using Antarctic analogies. J. Geophys. Res. 118, 1105-1117.

Knies, J., Spielhagen, R.F., 2016. A pan-Arctic ice shelf during late Marine Isotope Stage (MIS) 6: fact or fiction?. In: Abstracts, Past Gateways $4^{\text {th }}$ International Conference, pp. 45-46. Trondheim, Norway, 23-27 May 2016.

Knies, J., Nowaczyk, N., Müller, C., Vogt, C., Stein, R., 2000. A multiproxy approach to reconstruct the environmental changes along the Eurasian continental margin over the last 150000 years. Mar. Geol. 163, 317-344.

Knight, J., Coxon, P., McCabe, A.M., McCarron, S.G., 2004. Pleistocene glaciations in Ireland. In: Ehlers, J., Gibbard, P.L. (Eds.), Quaternary Glaciations Extent and Chronology - Part I: Europe. Elsevier, Amsterdam, pp. 183-191. Developments in Quaternary Sciences, 2.

Köhler, P., Bintanja, R., Fischer, H., Joos, F., Knutti, R., Lohmann, G., MassonDelmotte, V., 2010. What caused Earth's temperature variations during the last 800,000 years? Data-based evidence on radiative forcing and constraints on climate sensitivity. Quat. Sci. Rev. 29, 129-145.

Köhler, P., de Boer, B., von der Heydt, A.S., Stap, L.B., van de Wal, R., 2015. On the state dependency of the equilibrium climate sensitivity during the last 5 million years. Clim. Past. 11, 1801-1823.

Köhler, P., Bintanja, R., 2008. The carbon cycle during the mid Pleistocene transition: the southern ocean decoupling hypothesis. Clim. Past. 4, 311-332.

Krinner, G., Mangerud, J., Jakobsson, M., Crucifix, M., 2004. Enhanced ice sheet growth in Eurasia owing to adjacent ice-dammed lakes. Nature 427, 429-432.

Krinner, G., Boucher, O., Balkanski, Y., 2006. Ice-free glacial northern Asia due to dust deposition on snow. Clim. Dyn. 27, 613-625.

Kristoffersen, Y., Coakley, B., Jokat, W., Edwards, M., Brekke, H., Gjengedal, J., 2004. Seabed erosion on the Lomonosov Ridge, central Arctic Ocean: a tale of deep draft icebergs in the Eurasia Basin and the influence of Atlantic water inflow on iceberg motion? Paleoceanography 19. https://doi.org/10.1029/2003PA000985.

Kuijpers, A., Dalhoff, F., Brandt, M.P., Hümbs, P., Schott, T., Zotova, A., 2007. Giant iceberg plow marks at more than $1 \mathrm{~km}$ water depth offshore West Greenland. Mar. Geol. 246, 60-64.

Laban, C., van der Meer, J.J.M., 2004. Pleistocene glaciation in The Netherlands. In: Ehlers, J., Gibbard, P.L. (Eds.), Quaternary Glaciations Extent and Chronology Part I: Europe. Elsevier, pp. 251-260. Developments in Quaternary Sciences, 2.

Laban, C., van der Meer, J.J., 2011. Pleistocene glaciation in The Netherlands. In: Ehlers, J., Gibbard, P.L., Hughes, P.D. (Eds.), Quaternary Glaciations - Extent and Chronology: a Closer Look. Elsevier, pp. 247-260. Developments in Quaternary Science 15.

Lambeck, K., Chappell, J., 2001. Sea level change through the last glacial cycle. Science 292, 679-686.

Lambeck, K., Purcell, A., Funder, S., Kjær, K., Larsen, E., Moller, P.E.R., 2006. Constraints on the Late Saalian to early Middle Weichselian ice sheet of Eurasia from field data and rebound modelling. Boreas 35, 539-575.

Lambeck, K., Purcell, A., Zhao, J., Svensson, N.O., 2010. The scandinavian ice sheet: from MIS 4 to the end of the last glacial maximum. Boreas 39, 410-435.

Lambeck, K., Rouby, H., Purcell, A., Sun, Y., Sambridge, M., 2014. Sea level and global ice volumes from the Last Glacial Maximum to the Holocene. Proc. Natl. Acad. Sci. U.S.A. 111, 15296-15303.

Lambeck, K., Purcell, A., Zhao, S., 2017. The North American Late Wisconsin ice sheet and mantle viscosity from glacial rebound analyses. Quat. Sci. Rev. 158, $172-210$.

Landais, A., Dreyfus, G., Capron, E., Jouzel, J., Masson-Delmotte, V., Roche, D.M., Prié, F., Caillon, N., Chappellaz, J., Leuenberger, M., Lourantou, A., 2013. Twophase change in $\mathrm{CO}_{2}$, Antarctic temperature and global climate during Termination II. Nat. Geosci. 6, 1062-1065.

Larrasoaña, J.C., Roberts, A.P., Rohling, E.J., Winklhofer, M., Wehausen, R., 2003. Three million years of monsoon variability over the northern Sahara. Clim. Dyn. 21, 689-698.

Laskar, J., Robutel, P., Joutel, F., Gastineau, M., Correia, A.C.M., Levrard, B., 2004. A long-term numerical solution for the insolation quantities of the Earth. Astron. Astrophys. 428, 261-285.
Le Roy, I., 1994. Evolution des volcans en système de point chaud: île de Tahiti, Archipel de la Société (Polynésie Française). PhD thesis. University of Paris, 271 pp.

Lecavalier, B.S., Milne, G.A., Simpson, M.J., Wake, L., Huybrechts, P., Tarasov, L., Kjeldsen, K.K., Funder, S., Long, A.J., Woodroffe, S., Dyke, A.S., 2014. A model of Greenland ice sheet deglaciation constrained by observations of relative sea level and ice extent. Quat. Sci. Rev. 102, 54-84.

Liakka, J., Nilsson, J., Löfverström, M., 2012. Interactions between stationary waves and ice sheets: linear versus nonlinear atmospheric response. Clim. Dyn. 38, 1249-1262.

Liakka, J., Löverström, M., Colleoni, F., 2016. The impact of the North American glacial topography on the evolution of the Eurasian ice sheet over the last glacial cycle. Clim. Past. 12, 1225-1241.

Licciardi, J.M., Clark, P.U., Jenson, J.W., Macayeal, D.R., 1998. Deglaciation of a softbedded Laurentide ice sheet. Quat. Sci. Rev. 17, 427-448.

Lippstreu, L., 2002 (unpublished - see Lippstreu, L., Brose, F., Marcinek, J., 1995. Brandenburg. Das Quartär Deutschlands, 116-147.).

Lisiecki, L.E., Raymo, M.E., 2005. A Pliocene-Pleistocene stack of 57 globally distributed benthic $\delta^{18} \mathrm{O}$ records. Paleoceanography 20, PA1003,. https:// doi.org/10.1029/2004PA001071.

Litt, T., Behre, K.-E., Meyer, K.-D., Stephan, H.-J., Wansa, S., 2007. Stratigraphishe Begriffe für das Quartär des Norddeutschland Vereisungsgebietes. Quat. Sci. J. 56, 7-65.

Liverman, D.G., Catto, N.R., Rutter, N.W., 1989. Laurentide glaciation in west-central Alberta: a single (Late Wisconsinan) event. Canad. J. Earth Sci. 26, 266-274.

Lloyd, J.M., Kroon, D., Boulton, G.S., Laban, C., Fallick, A., 1996. Ice rafting history from the Spitsbergen ice cap over the last 200 kyr. Mar. Geol. 131, 103-121.

Löfverström, M., Caballero, R., Nilsson, J., Kleman, J., 2014. Evolution of the largescale atmospheric circulation in response to changing ice sheets over the last glacial cycle. Clim. Past. 10, 1453-1471.

Loulergue, L., Schilt, A., Spahni, R., Masson-Delmotte, V., Blunier, T., Lemieux, B. Barnola, J.M., Raynaud, D., Stocker, T.F., Chappellaz, J., 2008. Orbital and millennial-scale features of atmospheric $\mathrm{CH}_{4}$ over the past 800,000 years. Nature 453, 383-386.

Lourantou, A., Lavric, J.V., Koehler, P., Barnola, J.-M., Paillard, D., Michel, E., Raynaud, D., Chappellaz, J., 2010. Constraint of the $\mathrm{CO}_{2}$ rise by new atmospheric carbon isotopic measurements during the last deglaciation. Glob. Biogeochem. Cycles 24. https://doi.org/10.1029/2009GB003545.

Löwemark, L., Chao, W.S., Gyllencreutz, R., Hanebuth, T.J.J., Chiu, P.Y., Yang, T.N., Su, C.C., Chuang, C.K., Dominguez, D.C., Jakobsson, M., 2016. Variations in glacial and interglacial marine conditions over the last two glacial cycles off northern Greenland. Quat. Sci. Rev. 147, 164-177.

Mangerud, J., Astakhov, V., Svendsen, J.I., 2002. The extent of the barents-kara ice sheet during the last glacial maximum. Quat. Sci. Rev. 21, 111-119.

Mangerud, J., Jakobsson, M., Alexanderson, H., Astakhov, V., Clarke, G.K., Henriksen, M., Hjort, C., Krinner, G., Lunkka, J.P., Möller, P., Murray, A., 2004. Icedammed lakes and rerouting of the drainage of northern Eurasia during the Last Glaciation. Quat. Sci. Rev. 23, 1313-1332.

Marino, G., Rohling, E.J., Rodríguez-Sanz, L., Grant, K.M., Heslop, D., Roberts, A.P. Stanford, J.D., Yu, J., 2015. Bipolar seesaw control on last interglacial sea level. Nature 522, 197-201.

Marks, L., 2011. Quaternary glaciations in Poland. Dev. Quat. Sci. 15, 299-303.

Marks, L., 2012. Timing of the late vistulian (weichselian) glacial phases in Poland. Quat. Sci. Rev. 44, 81-88.

Marshall, S.J., Clark, P.U., 2002. Basal temperature evolution of North American ice sheets and implications for the 100-kyr cycle. Geophys. Res. Lett. 29, 671-674.

Marshall, S.J., James, T.S., Clarke, G.K., 2002. North American ice sheet reconstructions at the last glacial maximum. Quat. Sci. Rev. 21, 175-192.

Martin, P.A., Lea, D.W., Rosenthal, Y., Shackleton, N.J., Sarnthein, M., Papenfuss, T., 2002. Quaternary deep sea temperature histories derived from benthic foraminiferal Mg/Ca. Earth Planet. Sci. Lett. 198, 193-209.

Martínez-Botí, M.A., Foster, G.L., Chalk, T.B., Rohling, E.J., Sexton, P.F., Lunt, D.J., Pancost, R.D., Badger, M.P.S., Schmidt, D.N., 2015. Plio-Pleistocene climate sensitivity evaluated using high-resolution $\mathrm{CO}_{2}$ records. Nature 518, 49-54.

Martinson, D.G., Pisias, N.G., Hays, J.D., Imbrie, J., Moore, T.C., Shackleton, N.J., 1987 Age dating and the orbital theory of the ice ages: development of a highresolution 0 to 300,000-year chronostratigraphy. Quat. Res. 27, 1-29.

Matoshko, A.V., 2011. Chapter 31. Limits of the Pleistocene glaciation in the Ukraine: a closer look. In: Ehlers, J., Gibbard, P.L., Hughes, P.D. (Eds.), Quaternary Glaciations - Extent and Chronology: a Closer Look. Elsevier, Amsterdam, pp. 405-416. Developments in Quaternary Science 15.

Matoshko, A.V., Chugunny, Yu G., 1993. The Dnieper Glaciation of Ukraine (Geological Aspect). Naukova Dumka, Kiev, p. 192 (In Russian).

Matoshko, A.V., Chugunny, Yu G., 1995. Geological activity and dynamic evolution of the Dnieper glaciation. In: Ehlers, J., Kozarski, S., Gibbard, P.L. (Eds.), Glacial Deposits in North-East Europe. A.A. Balkema, Rotterdam, Brookfield, pp. 225-230.

Matthiessen, J., Knies, J., 2001. Dinoflagellate cyst evidence for warm interglacial conditions at the northern Barents Sea margin during marine oxygen isotope stage 5. J. Quat. Sci. 16, 727-737.

McKay III, E.D., Berg, R.C., 2008. Optical ages spanning two glacial-interglacial cycles from deposits of the ancient Mississippi river, north-central Illinois. Geol. Soc. Am. Abstr. Progr 40, 78.

McKay III, E.D., Berg, R.C., Hansel, A.K., Kemmis, T.J., Stumpf, A.J., 2008. Quaternary deposits and history of the ancient Mississippi river valley, north-centra 
Illinois. Ill. State Geol. Surv. Guideb. 35, 106 pp.

McKay, N.P., Overpeck, J.T., Otto-Bliesner, B.L., 2011. The role of ocean therma expansion in Last Interglacial sea level rise. Geophys. Res. Lett. 38, L14605. https://doi.org/10.1029/2011GL048280.

Mercer, J.H., 1970. A former ice sheet in the Arctic Ocean? Palaeogeogr. Palaeoclimatol. Palaeoecol. 8, 19-27.

Mitrovica, J.X., Wahr, J., Matsuyama, I., Paulson, A., 2005. The rotational stability of an ice-age earth. Geophys. J. Int. 161, 491-506.

Mix, A.C., Ruddiman, W.F., 1984. Oxygen-isotope analyses and Pleistocene ice volumes. Quat. Res. 21, 1-20.

Mix, A.C., Bard, E., Schneider, R., 2001. Environmental processes of the ice age: land oceans, glaciers (EPILOG). Quat. Sci. Rev. 20, 627-657.

Mohr, K., 1993. Tertiär und Quartär. In: Mohr, K. (Ed.), Geologie und Minerallagerstätten des Harzes. Schweizerbart Science Publications, Stuttgart, p. 384

Möller, P., Alexanderson, H., Funder, S., Hjort, C., 2015. The Taimyr Peninsula and the Severnaya Zemlya archipelago, Arctic Russia: a synthesis of glacial history and palaeo-environmental change during the Last Glacial cycle (MIS 5e-2). Quat. Sci. Rev. 107, 149-181.

Monnin, E., Indermühle, A., Dällenbach, A., Flückiger, J., Stauffer, B., Stocker, T.F. Raynaud, D., Barnola, J.M., 2001. Atmospheric $\mathrm{CO}_{2}$ concentrations over the last glacial termination. Science 291, 112-114.

Monnin, E., Steig, E.J., Siegenthaler, U., Kawamura, K., Schwander, J., Stauffer, B. Stocker, T.F., Morse, D.L., Barnola, J.M., Bellier, B., Raynaud, D., Fischer, H., 2004 Evidence for substantial accumulation rate variability in Antarctica during the Holocene, through synchronization of $\mathrm{CO}_{2}$ in the Taylor Dome, Dome $\mathrm{C}$ and DML ice cores. Earth Planet. Sci. Lett. 224, 45-54.

Montaggioni, L.F., 2005. History of Indo-Pacific coral reef systems since the last glaciation: development patterns and controlling factors. Earth Sci. Rev. 71, $1-75$.

Naafs, B.D.A., Hefter, J., Acton, G., Haug, G.H., Martínez-Garcia, A., Pancost, R Stein, R., 2012. Strengthening of north american dust sources during the late Pliocene (2.7 ma). Earth Planet. Sci. Lett. 317, 8-19.

Niessen, F., Hong, J.K., Hegewald, A., Matthiessen, J., Stein, R., Kim, H., Kim, S. Jensen, L., Jokat, W. Nam, S.I. Kang S.H., 2013, Repeated Pleistocene glaciation of the east siberian continental margin. Nat. Geosci. 6, 842-846.

Nørgaard-Pedersen, N., Mikkelsen, N., Lassen, S.J., Kristoffersen, Y., Sheldon, E., 2007. Reduced sea ice concentrations in the Arctic Ocean during the las interglacial period revealed by sediment cores off northern Greenland. Paleoceanography 22, PA1218,. https://doi.org/10.1029/2006PA001283.

O'Regan, M., Jakobsson, M., Kirchner, N., 2010. Glacial geological implications of overconsolidated sediments on the Lomonosov Ridge and Yermak plateau. Quat. Sci. Rev. 29, 3532-3544.

Obrochta, S.P., Crowley, T.J., Channell, J.E.T., Hodell, D.A., Baker, P.A., Seki, A. Yokoyama, Y., 2014. Climate variability and ice-sheet dynamics during the last three glaciations. Earth Planet. Sci. Lett. 406, 198-212.

Oglesby, R.J., 1990. Sensitivity of glaciation to initial snow cover, $\mathrm{CO}_{2}$, snow albedo and oceanic roughness in the NCAR CCM. Clim. Dyn. 4, 219-235.

Osborne, A.H., Vance, D., Rohling, E.J., Barton, N., Rogerson, M., Fello, N., 2008 A humid corridor across the Sahara for the migration "Out of Africa" of early modern humans 120,000 years ago. Proc. Natl. Acad. Sci. U. S. A. 105 $16444-16447$.

Palienko, V.P., 1982. Features of glacial relief of the Dnieper glacier marginal zone within Volyn' Polessie area. In: Bondarchuk, V.G. (Ed.), Materialy Po Izucheniyu Chetvertichnogo Perioda Na Teritorii Ukrainy. Naukova dumka, Kiev, pp. 203-211.

Parrenin, F., Masson-Delmotte, V., Köhler, P., Raynaud, D., Paillard, D., Schwander, J., Barbante, C., Landais, A., Wegner, A., Jouzel, J., 2013. Synchronous change of atmospheric $\mathrm{CO}_{2}$ and Antarctic temperature during the last deglacial warming. Science 339, 1060-1063.

Patton, H., Hubbard, A., Andreassen, K., Winsborrow, M., Stroeven, A.P., 2016. The build-up, configuration, and dynamical sensitivity of the Eurasian ice-sheet complex to Late Weichselian climatic and oceanic forcing. Quat. Sci. Rev. 153, 97-121.

Pattyn, F., 2010. Antarctic subglacial conditions inferred from a hybrid ice sheet/ice stream model. Earth Planet. Sci. Lett. 295, 451-461.

Pavey, R.R., Goldthwait, R.P., Brockman, C.S., Hull, D.N., Swinford, E.M., Van Horn, R.G., 1999. Quaternary Geology of Ohio. Ohio Division of Geological Survey. Map No. 2.

Payne, A.J., 1995. Limit cycles in the basal thermal regime of ice sheets. J. Geophys. Res. 100, 4249-4263.

Peltier, W.R., 1994. Ice age paleotopography. Science 265, 195-201.

Peltier, W.R., 1996. Mantle viscosity and ice-age ice sheet topography. Science 273 1359-1364.

Peltier, W.R., 2004. Global glacial isostasy and the surface of the ice-age Earth: the ICE-5G (VM2) model and GRACE. Ann. Rev. Earth Planet. Sci. 32, 111-149.

Peltier, W.R., Argus, D.F., Drummond, R., 2015. Space geodesy constrains ice-age terminal deglaciation: the global ICE-6G_C (VM5a) model. J. Geophys. Res. $120,450-487$

Peyaud, V., 2006. Rôle de la dynamique des calottes glaciaires dans les grands changements climatiques des périodes glaciaires-interglaciaires. $\mathrm{PhD}$ thesis. Université Joseph-Fourier-Grenoble, 247 pp.

Polyak, L., Edwards, M.H., Coakley, B.J., Jakobsson, M., 2001. Ice shelves in the Pleistocene Arctic Ocean inferred from glaciogenic deep-sea bedforms. Nature 410, 453-457.

Polyak, L., Curry, W.B., Darby, D.A., Bischof, J., Cronin, T.M., 2004. Contrasting glacial/ interglacial regimes in the western Arctic Ocean as exemplified by a sedimentary record from the Mendeleev Ridge. Palaeogeogr. Palaeoclimatol. Palaeoecol. 203, 73-93.

Polyak, L., Bischof, J., Ortiz, J.D., Darby, D.A., Channell, J.E.T., Xuan, C., Kaufman, D.S., Løvlie, R., Schneider, D.A., Eberl, D.D., Adler, R.E., 2009. Late Quaternary stratigraphy and sedimentation patterns in the western Arctic Ocean. Glob. Planet. Chang. 68, 5-17.

Polyak, L., Alley, R.B., Andrews, J.T., Brigham-Grette, J., Cronin, T.M., Darby, D.A., Dyke, A.S., Fitzpatrick, J.J., Funder, S., Holland, M., Jennings, A.E., 2010. History of sea ice in the Arctic. Quat. Sci. Rev. 29, 1757-1778.

Potter, E.K., Lambeck, K., 2003. Reconciliation of sea-level observations in the Western North Atlantic during the last glacial cycle. Earth Planet. Sci. Lett. 217, $171-181$.

Putkonen, J., Swanson, T., 2003. Accuracy of cosmogenic ages for moraines. Quat. Res. 59, 255-261.

Rabineau, M., Berné, S., Olivet, J.L., Aslanian, D., Guillocheau, F., Joseph, P., 2006 Paleo sea levels reconsidered from direct observation of paleoshoreline position during Glacial Maxima (for the last 500,000 yr). Earth Planet. Sci. Lett. 252, 119-137.

Raymo, M.E., Lisiecki, L.E., Nisancioglu, K.H., 2006. Plio-Pleistocene ice volume, Antarctic climate, and the global $\delta^{18} \mathrm{O}$ record. Science 313, 492-495.

Reimer, P.J., Bard, E., Bayliss, A., Beck, J.W., Blackwell, P.G., Ramsey, C.B., Buck, C.E., Cheng, H., Edwards, R.L., Friedrich, M., Grootes, P.M., 2013. INTCAL13 and MARINE13 radiocarbon age calibration curves $0-50,000$ years cal BP. Radiocarbon 55, 1869-1887.

Ringler, T.D., Cook, K.H., 1997. Factors controlling nonlinearity in mechanically forced stationary waves over orography. J. Atmos. Sci. 54, 2612-2629.

Roe, G.H., Lindzen, R.S., 2001. The mutual interaction between continental-scale ice sheets and atmospheric stationary waves. J. Clim. 14, 1450-1465.

Rohling, E.J., Fenton, M., Jorissen, F.J., Bertrand, P., Ganssen, G., Caulet, J.P., 1998. Magnitudes of sea-level lowstands of the past 500,000 years. Nature 394, $162-165$.

Rohling, E.J., Cane, T.R., Cooke, S., Sprovieri, M., Bouloubassi, I., Emeis, K.C., Schiebel, R., Kroon, D., Jorissen, F.J., Lorre, A., Kemp, A.E.S., 2002. African monsoon variability during the previous interglacial maximum. Earth Planet. Sci. Lett. 202, 61-75.

Rohling, E.J., Sprovieri, M., Cane, T. Casford, J.S., Cooke, S., Bouloubassi, I., Emeis, K.C., Schiebel, R., Rogerson, M., Hayes, A., Jorissen, F.J., 2004. Reconstructing past planktic foraminiferal habitats using stable isotope data: a case history for Mediterranean sapropel S5. Mar. Micropal 50, 89-123.

Rohling, E.J., Grant, K., Hemleben, C.H., Siddall, M., Hoogakker, B.A.A., Bolshaw, M., Kucera, M., 2008. High rates of sea-level rise during the last interglacial period. Nat. Geosci. 1, 38-42.

Rohling, E.J., Grant, K., Bolshaw, M., Roberts, A.P., Siddall, M., Hemleben, C., Kucera, M., 2009. Antarctic temperature and global sea level closely coupled over the past five glacial cycles. Nat. Geosci. 2, 500-504.

PALAEOSENS Project Members, Rohling, E.J., Sluijs, A., Dijkstra, H.A., Köhler, P., van de Wal, R.S.W, von der Heydt, A.S., Beerling. D., Berger, A., Bijl, P. Crucifix, M., deConto, R., Drijfhout, S.S., Fedorov, A., Foster, G., Ganopolski, A., Hansen, J., Hönisch, B., Hooghiemstra, H., Huber, M., Huybers, P., Knutti, R., Lea, D.W., Lourens, L.J., Lunt, D., Masson-Demotte, V., Medina-Elizalde, M., OttoBliesner, B., Pagani, M., Pälike, H., Renssen, H., Royer, D.L., Siddall, M., Valdes, P., Zachos, J.C., Zeebe, R.E., 2012. Making sense of palaeoclimate sensitivity. Nature 491, 683-691.

Rohling, E.J., Medina-Elizalde, M., Shepherd, J.G., Siddall, M., Stanford, J.D., 2012. Sea surface and high-latitude temperature sensitivity to radiative forcing of climate over several glacial cycles. J. Clim. 25, 1635-1656.

Rohling, E.J., Foster, G.L., Grant, K.M., Marino, G., Roberts, A.P., Tamisiea, M.E., Williams, F., 2014. Sea-level and deep-sea-temperature variability over the past 5.3 million years. Nature 508, 477-482.

Rohling, E.J., Marino, G., Grant, K.M., 2015. Mediterranean climate and oceanography, and the periodic development of anoxic events (sapropels). Earth-Sci. Rev. 143, 62-97.

Rose, J., 2009. Early and middle Pleistocene landscapes of eastern England. Proc. Geol. Assoc. 120, 3-33.

Rose, J., Candy, I., Moorlock, B.S.P., Wilkins, H., Lee, J.A., Hamblin, R.J.O., Lee, J.R., Riding, J.B., Morigi, A.N., 2002. Early and early Middle Pleistocene river, coastal and neotectonic processes, southeast Norfolk, England. Proc. Geol. Assoc. 113, 47-67.

Rovey, C.W., Balco, G., 2011. Summary of early and middle Pleistocene glaciations in northern Missouri, USA. In: Ehlers, J., Gibbard, P.L., Hughes, P.D. (Eds.), Quaternary Glaciations - Extent and Chronology: a Closer Look. Elsevier, pp. 553-562. Developments in Quaternary Science 15.

Ruddiman, W.E., 1977. Late Quaternary deposition of ice-rafted sand in the subpolar North Atlantic (40-60 N). Geol. Soc. Am. Bull. 88, 1813-1827.

Ruzicka, M., 2004. The Pleistocene glaciation of Czechia. In: Ehlers, J., Gibbard, P.L (Eds.), Quaternary Glaciations Extent and Chronology - Part I: Europe. Elsevier, Amsterdam, pp. 27-34. Developments in Quaternary Sciences, 2.

Schmitt, J., Schneider, R., Elsig, J., Leuenberger, D., Lourantou, A., Chappellaz, J., Köhler, P., Joos, F., Stocker, T.F., Leuenberger, M., Fischer, H., 2012. Carbon isotope constraints on the deglacial $\mathrm{CO}_{2}$ rise from ice cores. Science 336, 711-714.

Schneider, R., Schmitt, J., Koehler, P., Joos, F., Fischer, H., 2013. A reconstruction of atmospheric carbon dioxide and its stable carbon isotopic composition from the penultimate glacial maximum to the last glacial inception. Clim. Past. 9, 2507-2523. 
Schott, F.A., Xie, S.-P., McCreary Jr., J.P., 2009. Indian Ocean circulation and climate variability. Rev. Geophys. 47, RG1002. https://doi.org/10.1029/2007RG000245.

Schrag, D.P., Adkins, J.F., McIntyre, K., Alexander, J.L., Hodell, D.A., Charles, C.D., McManus, J.F., 2002. The oxygen isotopic composition of seawater during the Last Glacial Maximum. Quat. Sci. Rev. 21, 331-342.

Scrivner, A.E., Vance, D., Rohling, E.J., 2004. New neodymium isotope data quantify Nile involvement in Mediterranean anoxic episodes. Geology 32, 565-568.

Seguinot, J., Khroulev, C., Rogozhina, I., Stroeven, A.P., Zhang, Q., 2014. The effect of climate forcing on numerical simulations of the Cordilleran ice sheet at the Last Glacial Maximum. Cryosphere 8, 1087-1103.

Seidel, G., 2003. Geologische Ubersichtskarte von Thüringen 1:200,000. In: Seidel, G. (Ed.), Geologie von Thüringen. Schweizerbart Science Publishers, Stuttgart, p. 548.

Sejrup, H.P., Hjelstuen, B.O., Dahlgren, K.T., Haflidason, H., Kuijpers, A., Nygård, A., Praeg, D., Stoker, M.S., Vorren, T.O., 2005. Pleistocene glacial history of the NW European continental margin. Mar. Petrol. Geol. 22, 1111-1129.

Shakun, J.D., Lea, D.W., Lisiecki, L.E., Raymo, M.E., 2015. An 800-kyr record of global surface ocean $\delta^{18} \mathrm{O}$ and implications for ice volume-temperature coupling. Earth Planet. Sci. Lett. 426, 58-68.

Siani, G., Paterne, M., Arnold, M., Bard, E., Métivier, B., Tisnerat, N., Bassinot, F., 2000. Radiocarbon reservoir ages in the mediterranean sea and black sea. Radiocarbon 42, 271-280.

Siddall, M., Rohling, E.J., Almogi-Labin, A., Hemleben, C., Meischner, D., Schmelzer, I., Smeed, D.A., 2003. Sea-level fluctuations during the last glacial cycle. Nature $423,853-858$.

Siddall, M., Smeed, D.A., Hemleben, C., Rohling, E.J., Schmelzer, I., Peltier, W.R., 2004. Understanding the Red Sea response to sea level. Earth Planet. Sci. Lett. 225, $421-434$.

Siddall, M., Hönisch, B., Waelbroeck, C., Huybers, P., 2010. Changes in deep Pacific temperature during the mid-Pleistocene transition and Quaternary. Quat. Sci. Rev. 29, 170-182.

Siegert, M.J., Dowdeswell, J.A., Hald, M., Svendsen, J.I., 2001. Modelling the eurasian ice sheet through a full (weichselian) glacial cycle. Glob. Planet. Change 31, $367-385$.

Simpson, M.J.R., Milne, G.A., Huybrechts, P., Long, A.J., 2009. Calibrating a glaciological model of the Greenland ice sheet from the Last Glacial Maximum to present-day using field observations of relative sea level and ice extent. Quat. Sci. Rev. 28, 1631-1657.

Sivan, D., Sisma-Ventura, G., Greenbaum, N., Bialik, O.M., Williams, F.H., Tamisiea, M.E., Rohling, E.J., Frumkin, A., Avnaim-Katav, S., Shtienberg, G., Stein, M., 2016. Eastern Mediterranean sea levels through the last interglacial from a coastal-marine sequence in northern Israel. Quat. Sci. Rev. 145, 204-225.

Skinner, L.C., Shackleton, N.J., 2005. An Atlantic lead over Pacific deep-water change across Termination I: implications for the application of the marine isotope stage stratigraphy. Quat. Sci. Rev. 24, 571-580.

Snyder, C.W., 2016a. Bayesian hierarchical regression analysis of variations in sea surface temperature change over the past million years. Paleoceanography 31, $1283-1300$

Snyder, C.W., 2016b. Evolution of global temperature over the past two million years. Nature $538,226-228$.

Sosdian, S., Rosenthal, Y., 2009. Deep-sea temperature and ice volume changes across the Pliocene-Pleistocene climate transitions. Science 325, 306-310.

Spielhagen, R.F., Baumann, K.H., Erlenkeuser, H., Nowaczyk, N.R., NørgaardPedersen, N., Vogt, C., Weiel, D., 2004. Arctic Ocean deep-sea record of northern Eurasian ice sheet history. Quat. Sci. Rev. 23, 1455-1483.

Stein, R., Fahl, K., Gierz, P., Niessen, F., Lohmann, G., 2017. Arctic Ocean sea ice cover during the penultimate glacial and the last interglacial. Nat. Commun. 8, 373. https://doi.org/10.1038/s41467-017-00552-1.

Stenni, B., Masson-Delmotte, V., Selmo, E., Oerter, H., Meyer, H., Röthlisberger, R., Jouzel, J., Cattani, O., Falourd, S., Fischer, H., Hoffmann, G., 2010. The deuterium excess records of EPICA Dome $C$ and Dronning Maud Land ice cores (East Antarctica). Quat. Sci. Rev. 29, 146-159.

Stirling, C.H., Esat, T.M., McCulloch, M.T., Lambeck, K., 1995. High-precision U-series dating of corals from Western Australia and implications for the timing and duration of the Last Interglacial. Earth Planet. Sci. Lett. 135, 115-130.

Stocker, T.F., Qin, D., Plattner, G.K., Tignor, M., Allen, S.K., Boschung, J., Nauels, A., Xia, Y., Bex, V., Midgley, P.M., 2013. Climate Change 2013: the Physical Science Basis. Contribution of Working Group I to the Fifth Assessment Report of the Intergovernmental Panel on Climate Change. Cambridge University Press, Cambridge, UK, 1535 pp.

Stokes, C.R., Tarasov, L., Blomdin, R., Cronin, T.M., Fisher, T.G., Gyllencreutz, R., Hättestrand, C., Heyman, J., Hindmarsh, R.C., Hughes, A.L., Jakobsson, M., 2015. On the reconstruction of palaeo-ice sheets: recent advances and future challenges. Quat. Sci. Rev. 125, 15-49.

Straw, A., 1979. The Devensian glaciation. In: Straw, A., Clayton, K.M. (Eds.), The Geomorphology of the British Isles: Eastern and Central England. Methuen, London, pp. 21-45.

Stroeven, A.P., Fabel, D., Codilean, A.T., Kleman, J., Clague, J.J., MiguensRodriguez, M., Xu, S., 2010. Investigating the glacial history of the northern sector of the Cordilleran Ice Sheet with cosmogenic 10Be concentrations in quartz. Quat. Sci. Rev. 29, 3630-3643.

Stroeven, A.P., Fabel, D., Margold, M., Clague, J.J., Xu, S., 2014. Investigating absolute chronologies of glacial advances in the NW sector of the Cordilleran Ice Sheet with terrestrial in situ cosmogenic nuclides. Quat. Sci. Rev. 92, 429-443.

Svendsen, J.I., Alexanderson, H., Astakhov, V.I., Demidov, I., Dowdeswell, J.A.,
Funder, S., Gataullin, V., Henriksen, M., Hjort, C., Houmark-Nielsen, M., Hubberten, H.W., 2004. Late quaternary ice sheet history of northern Eurasia. Quat. Sci. Rev. 23, 1229-1271.

Syverson, K.M., Colgan, P.M., 2011. The Quaternary of Wisconsin: an updated review of stratigraphy, glacial history and landforms. In: Ehlers, J., Gibbard, P.L., Hughes, P.D. (Eds.), Quaternary Glaciations - Extent and Chronology: a Closer Look. Elsevier, Amsterdam, pp. 537-552. Developments in Quaternary Science 15.

Szabo, J.P., Totten, S.M., 1995. Multiple pre-Wisconsinan glaciations along the northwestern edge of the Allegheny Plateau in Ohio and Pennsylvania. Canad. J. Earth Sci. 32, 2081-2089.

Szabo, J.P., Angle, M.P., Eddy, A.M., 2011. Pleistocene glaciation of Ohio, USA. In: Ehlers, J., Gibbard, P.L., Hughes, P.D. (Eds.), Quaternary Glaciations - Extent and Chronology: a Closer Look. Elsevier, Amsterdam, pp. 521-529. Developments in Quaternary Science 15.

Tamisiea, M.E., 2011. Ongoing glacial isostatic contributions to observations of sea level change. Geophys. J. Int. 186, 1036-1044.

Tarasov, L., Dyke, A.S., Neal, R.M., Peltier, W.R., 2012. A data-calibrated distribution of deglacial chronologies for the North American ice complex from glaciological modeling. Earth Planet. Sci. Lett. 315, 30-40.

Thomas, A.L., Henderson, G.M., Deschamps, P., Yokoyama, Y., Mason, A.J., Bard, E., Hamelin, B., Durand, N., Camoin, G., 2009. Penultimate deglacial sea-level timing from uranium/thorium dating of Tahitian corals. Science 324, 1186-1189.

Toucanne, S., Zaragosi, S., Bourillet, J.F., Cremer, M., Eynaud, F., Van Vliet-Lanoë, B., Penaud, A., Fontanier, C., Turon, J.L., Cortijo, E., Gibbard, P.L., 2009. Timing of massive 'Fleuve Manche' discharges over the last 350kyr: insights into the European ice-sheet oscillations and the European drainage network from MIS 10 to 2. Quat. Sci. Rev. 28, 1238-1256.

Turner, D.G., Ward, B.C., Bond, J.D., Jensen, B.J., Froese, D.G., Telka, A.M., Zazula, G.D., Bigelow, N.H., 2013. Middle to Late Pleistocene ice extents, tephrochronology and paleoenvironments of the White River area, southwest Yukon. Quat. Sci. Rev. 75, 59-77.

Turney, C.S.M., Jones, R.T., 2010. Does the Agulhas Current amplify global temperatures during super-interglacials? J. Quat. Sci. 25, 839-843.

Ullman, D.J., LeGrande, A.N., Carlson, A.E., Anslow, F.S., Licciardi, J.M., 2014 Assessing the impact of Laurentide Ice Sheet topography on glacial climate. Clim. Past. 10, 487-507.

van den Berg, J., van de Wal, R., Oerlemans, H., 2008. A mass balance model for the Eurasian Ice Sheet for the last 120,000 years. Glob. Planet. Change 61, 194-208.

Velichko, A.A., Faustova, M.A., Pisareva, V.V., Gribchenko, Y.N., Sudakova, N.G., Lavrentiev, N.V., 2011. Glaciations of the east European Plain: distribution and chronology. In: Ehlers, J., Gibbard, P.L., Hughes, P.D. (Eds.), Quaternary Glaciations - Extent and Chronology: a Closer Look. Elsevier, Amsterdam, pp. 337-359. Developments in Quaternary Science 15. Developments in Quaternary Science 15.

Veres, D., Bazin, L., Landais, A., Toyé Mahamadou Kele, H., Lemieux-Dudon, B., Parrenin, F., Martinerie, P., Blayo, E., Blunier, T., Capron, E., Chappellaz, J., 2013. The Antarctic ice core chronology (AICC2012): an optimized multi-parameter and multi-site dating approach for the last 120 thousand years. Clim. Past. 9, 1733-1748.

Vogt, P.R., Crane, K., Sundvor, E., 1994. Deep Pleistocene iceberg plowmarks on the Yermak Plateau: sidescan and $3.5 \mathrm{kHz}$ evidence for thick calving ice fronts and a possible marine ice sheet in the Arctic Ocean. Geology 22, 403-406.

Waelbroeck, C., Labeyrie, L., Michel, E., Duplessy, J.C., McManus, J.F., Lambeck, K., Balbon, E., Labracherie, M., 2002. Sea-level and deep water temperature changes derived from benthic foraminifera isotopic records. Quat. Sci. Rev. 21, 295-305.

Wainer, K.A.I., Rowe, M.P., Thomas, A.L., Mason, A.J., Williams, B., Tamisiea, M.E. Williams, F.H., Düsterhus, A., Henderson, G.M., 2017. Speleothem evidence for MIS 5c and 5a sea level above modern level at Bermuda. Earth Planet. Sci. Lett. 457, 325-334.

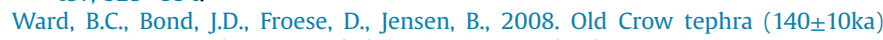
constrains penultimate Reid glaciation in central Yukon Territory. Quat. Sci. Rev. 27, 1909-1915.

Webb, N.D., Grimley, D.A., Phillips, A.C., Fouke, B.W., 2012. Origin of glacial ridges (OIS 6) in the Kaskaskia Sublobe, southwestern Illinois, USA. Quat. Res. 78, $341-352$.

Wekerle, C., Colleoni, F., Naslund, J.-O., Brandefelt, J., Masina, S., 2016. Numerical reconstructions of the penultimate glacial maximum Northern Hemisphere ice sheets: sensitivity to climate forcing and model parameters. J. Glaciol. 62, 607-622.

Weldeab, S., Emeis, K.C., Hemleben, C., Schmiedl, G., Schulz, H., 2003a. Spatial productivity variations during formation of sapropels S5 and S6 in the Mediterranean Sea: evidence from Ba contents. Palaeogeogr. Palaeoclimatol. Palaeoecol. 191, 169-190.

Weldeab, S., Siebel, W., Wehausen, R., Emeis, K.C., Schmiedl, G., Hemleben, C., 2003b. Late Pleistocene sedimentation in the Western Mediterranean Sea: implications for productivity changes and climatic conditions in the catchment areas. Palaeogeogr. Palaeoclimatol. Palaeoecol. 190, 121-137.

Whitehouse, P.L., Bentley, M.J., Le Brocq, A.M., 2012. A deglacial model for Antarctica: geological constraints and glaciological modelling as a basis for a new model of Antarctic glacial isostatic adjustment. Quat. Sci. Rev. 32, 1-24.

Williams, F.H., 2016. A Geophysical Approach to Reconstructing Past Global Mean Sea Levels Using Highly Resolved Sea-level Records. PhD Thesis. University of 
Southampton, UK, 503 pp.

Williams, D.F., Moore, W.S., Fillon, R.H., 1981. Role of glacial Arctic Ocean ice sheets in Pleistocene oxygen isotope and sea level records. Earth Planet. Sci. Lett. 56, $157-166$

Yamane, M., Yokoyama, Y., Abe-Ouchi, A., Obrochta, S., Saito, F., Moriwaki, K. Matsuzaki, H., 2015. Exposure age and ice-sheet model constraints on Pliocene East Antarctic ice sheet dynamics. Nat. Commun. 6, 7016,. https://doi.org/ 10.1038/ncomms8016.

Yokoyama, Y., Esat, T.M., 2011. Global climate and sea level - enduring variability and rapid fluctuations over the past 150,000 years. Oceanography 24, 54-69.

Young, R.R., Burns, J.A., Smith, D.G., Arnold, L.D., Rains, R.B., 1994. A single, late Wisconsin, Laurentide glaciation, Edmonton area and southwestern Alberta. Geology 22, 683-686.

\section{Further Reading}

Arkhipov, S.A., 1990. Explanatory Note to the Regional Stratigraphic Scheme of the Quaternary of the West Siberian Plain. Institute of Geology and Geophysics, Siberian Branch of Academy of Sciences of USSR, Novosibirsk, p. 95 (in Russian).

Arkhipov, S.A., 1989. A chronostratigraphic scale of the glacial pleistocene of the West Siberian North. In: Skabichevskaya, N.A. (Ed.), Pleistotsen Sibiri. Stratigrafia I Mezhregionalnye Korrelatsii. Nauka, Novosibirsk (in Russian).

Arkhipov, S.A., Levchuk, L.K., Shelkoplyas, V.N., 1994. Stratigraphy and geological structure of Quaternary cover in the lower-Ob-Yamal-Taz region, West Siberia. Russ. J. Geol. Geophys. 35, 74-89 (in Russian).

Arkhipov, S.A., Levchuk, L.K., Shelkoplyas, V.N., 1992. Marine quaternary sediments of the lower ob. In: Murzayeva, V.E., Punning, J.-M.K., Chichagova, O.A. (Eds.), Geokhronolohgia Chetvertichnogo Perioda. Nauka, Moscow, pp. 90-101 (in Russian).

Arkhipov, S.A., Panychev, V.A., Shelekhova, T.G., Shelkoplyas, V.N., 1978. Glacial Geology of the Belogorsk Upland, the West Siberian Plain, the Lower Ob Region. Siberian Branch of Academy of Sciences of the USSR, Novosibirsk, p. 132.

Armstrong, J.E., 1981. Post-Vashon Wisconsin Glaciation, Fraser Lowland, British Columbia (No. 322). Geological Survey of Canada, Ottawa, p. 34. ON Paper.

Armstrong, J.E., 1975. Quaternary Geology, Stratigraphic Studies and Revaluation of Terrain Inventory Maps, Fraser Lowland, British Columbia. Geological Survey of Canada, Ottawa, pp. 377-380. ON Paper. Number 75-1A.

Arslanov, K.A., Maksimov, F.E., Kuznetsov, V.Y., Chernov, S.B., Velichkevich, F.Y. Razina, V.V., Kuzmin, G.F., Baranova, N.G., 2005. U-Th age and paleobotanical characteristics of the interglacial peat in the Rodionovo key section. In: Yushkin, N.P. (Ed.), Proceedings of the IV All-Russia Quaternary Congress. Geoprint, Syktyvkar, pp. 21-23 (in Russian).

Arslanov, K.A, Yevzerov, V.Y., Tertichnyi, N.I, Gerasimov, S.A Lokshin, N.V., 1981 Kvoprocu o vozraste otlozhenii borealnoi transgressii (ponoiskikh sloev) na Kolskom poluostrove (On the age of deposits (Ponoi layers) Boreal transgression in the Kola Peninsula). In: Pleistotsenovye Oledeneniya Vostochno-evropeisko Ravniny (Pleistocene Glaciations at the East European Plain). Nauka, Moscow, pp. 28-37 (in Russian).

Astakhov, V.I., 2013. Pleistocene glaciations of northern Russia-a modern view. Boreas 42 (1), 1-24.

Astakhov, V., 2011. Ice margins of Northern Russia revisited. In: Ehlers, J., Gibbard, P.L., Hughes, P.D. (Eds.), Quaternary Glaciations - Extent and Chronology, a Closer Look, Developments in Quaternary Science, vol. 15. Elsevier, Amsterdam, pp. 323-336.

Astakhov, V.I., 2006. Evidence of Late pleistocene ice-dammed lakes in West Siberia. Boreas 35, 607-621.

Astakhov, V.I., 2004. Middle pleistocene glaciations of the Russian North. Quat. Sci. Rev. 23, 1285-1311.

Astakhov, V., Mangerud, J., 2007. The geochronometric age of Late Pleistocene terraces on the lower Yenisei. Dokl. Earth Sci. 416, 1022-1026.

Astakhov, V., Nazarov, D., 2010. Correlation of upper pleistocene sediments in northern West Siberia. Quat. Sci. Rev. 29, 3615-3629.

Astakhov, V.I., Mangerud, J., Svendsen, J.I., 2007. Trans-uralian correlation of the northern upper pleistocene. Reg. Geol. i Metallog. 30/31, 190-206 (in Russian).

Astakhov, V.I., Arslanov, K.A., Maksimov, F.E., Kuznetsov, V.Y., Razina, V.V., Nazarov, D.V., 2005. The age of interglacial peat on the Lower Ob. Dokl. Earth Sci. 401, 298-302.

Ballantyne, C.K. Hall, A.M., 2008. The altitude of the last ice sheet in Caithness and east Sutherland, northern Scotland. Scott. J. Geol. 44 (2), 169-181.

Ballantyne, C.K., Stone, J.O., Fifield, L.K., 2009. Glaciation and deglaciation of the SW Lake District, England: implications of cosmogenic $36 \mathrm{Cl}$ exposure dating. Proc. Geol. Assoc. 120, 139-144.

Baltrūnas, V., Šeirienè, V., Molodkov, A., Zinkutè, R., Katinas, V., Karmaza, B. Kisielienè, D., Petrošius, R., Taraškevičius, R., Piličiauskas, G., Schmölcke, U., 2013. Depositional environment and climate changes during the late Pleistocene as recorded by the Netiesos section in southern Lithuania. Quat. Int. 292 $136-149$.

Bardeyeva, M.A., 1986. The key sections of quaternary deposits in the central Siberian upland. In: Velichko, A.A., Isayeva, L.L. (Eds.), Chetvertichnye Oledeneniya Srednei Sibiri. Nauka, Moscow, pp. 35-52 (in Russian).

Bardeyeva, M.A., Isayeva, L.L., Andreyeva, S.M., Kind, N.V., Nikolskaya, M.V. Pirumova, L.G., Sulerzhitsky, L.D., Cherkasova, N.N., 1980. Stratigraphy, Geochronology and Palaeogeography of the Pleistocene and Holocene of the Northern Central Siberian Upland. Geokhronologia Chetvertichnogo Perioda.
Nauka, Moscow, pp. 198-207.

Barendregt, R.W. 2011. Magnetostratigraphy of quaternary sections in eastern Alberta. In: Ehlers, J., Gibbard, P.L., Hughes, P.D. (Eds.), Quaternary Glaciations Extent and Chronology, a Closer Look, Developments in Quaternary Science, vol. 15. Elsevier, Amsterdam, pp. 591-600.

Ber, A., 2006. Pleistocene interglacials and glaciations of northeastern Poland compared to neighbouring areas. Quat. Int. 149, 12-23.

Berg, R.C., McKay III, E.D., Stiff, B.J., 2012. Elevation of the Basal Sand and Gravel of the Middle Illinois River Valley, Bureau, LaSalle, Marshall, Peoria, Putnam, and Woodford Counties, Illinois. Illinois State Geological Survey. Illinois Map 17. Scale 1:62,500.

Bobrowsky, P., 1987. Quaternary Stratigraphy of the Northern Canadian Cordillera Based on New Evidence from the Finlay River of Northeastern British Columbia. International Quaternary Association, Xllth International Congress, Ottawa, p. 132.

Bobrowsky, P., Rutter, N.W., 1992. The quaternary geologic history of the Canadian rocky mountains. Géogr. Physique Quaternaire 46, 5-50.

Bolshiyanov, D., Molodkov, A., 1999. Marine Pleistocene deposits of the Taymyr Peninsula and their age from ESR dating. In: Kassens, H., Bauch, H.A., Dmitrenko, I.A., Eicken, H., Hubberten, H.-W., Melles, M., Thiede, J. Timochov, L.A. (Eds.), Land-ocean Systems in the Siberian Arctic. Dynamics and History. Springer-Verlag, Berlin, pp. 469-475.

Börner, A., Hrynowiecka, A., Kuznetsov, V., Stachowicz-Rybka, R., Maksimov, F. Grigoriev, V., Niska, M., Moskal-del Hoyo, M., 2015. Palaeoecological investigations and $230 \mathrm{Th} / \mathrm{U}$ dating of Eemian interglacial peat sequence of Banzin (Mecklenburg-Western Pomerania, NE-Germany). Quat. Int. 386, $122-136$.

Brzezina, R., 2000. Detailed Geological Map of Poland at 1:50000 Scale, Sheet Krzesk. Polish Geological Institute, Warszawa.

Busschers, F.S., van Balen, R.T., Cohen, K.M., Kasse, C., Weerts, H.J.T., Wallinga, J., Bunnik, F.P.M., 2008. Response of the Rhine-Meuse fluvial system to Saalian ice sheet dynamics. Boreas 37, 377-398.

Busschers, F.S., Kasse, C., Van Balen, R.T., Vandenberghe, J., Cohen, K.M., Weerts, HJT, Wallinga, J. Johns, C. Cleveringa, P, Bunnik, F.P.M., 2007, Late Pleistocene evolution of the Rhine-Meuse system in the southern North Sea basin: imprints of climate change, sea-level oscillation and glacio-isostacy. Quat. Sci. Rev. 26, 3216-3248.

Busschers, F.S., Weerts, H.J.T., Wallinga, J., Cleveringa, P., Kasse, C., Wolf, H.D., Cohen, K.M., 2005. Sedimentary architecture and optical dating of Middle and Late Pleistocene Rhine-Meuse deposits-fluvial response to climate change, sealevel fluctuation and glaciation. Geol. Mijnb. 84, 25-41.

Catt, J.A., 2007. The Pleistocene glaciations of eastern Yorkshire: a review. Proc. Yorks. Geol. Soc. 56, 177-207.

Counts, R.C., Murari, M.K., Owen, L.A., Mahan, S.A., Greenan, M., 2015. Late Quaternary chronostratigraphic framework of terraces and alluvium along the lower Ohio River, southwestern Indiana and western Kentucky. USA. Quat. Sci. Rev. 110, 72-91.

Curry, B.B., 1998. Evidence at lomax, Illinois, for Mid-Wisconsin ( 40,000 yr BP) position of the Des Moines LLobe and for diversion of the Mississippi river by the Lake Michigan Lobe (20,350 yr BP). Quat. Res. 50, 128-138.

Curry, B.B., Baker, R.G., 2000. Palaeohydrology, vegetation, and climate since the late Illinois Episode $(\sim 130 \mathrm{ka})$ in south-central Illinois. Palaeogeogr. Palaeoclimatol. Palaeoecol. 155, 59-81.

Curry, B.B., Pavich, M.J., 1996. Absence of glaciation in Illinois during marine isotope stages 3 through 5. Quat. Res. 46, 19-26.

Curry, B.B., Troost, K.G., Berg, R.C., 1994. Quaternary geology of the Martinsville alternative site, Clark County, Illinois, a proposed low level radioactive waste disposal site. Ill. State Geol. Surv, Circ, 556, 85.

Demuro, M., Froese, D.G., Arnold, L.J., Roberts, R.G., 2012. Single-grain OSL dating of glaciofluvial quartz constrains Reid glaciation in NW Canada to MIS 6. Quat. Res. 77, 305-316.

Duk-Rodkin, A., Barendregt, R.W., 2011. Stratigraphical record of glacials/interglacials in northwest Canada. In: Ehlers, J., Gibbard, P.L., Hughes, P.D. (Eds.), Quaternary Glaciations - Extent and Chronology, a Closer Look, Developments in Quaternary Science, vol. 15. Elsevier, Amsterdam, pp. 661-698.

Duk-Rodkin, A., Barendregt, R.W., White, J.M., 2010. An extensive late Cenozoic terrestrial record of multiple glaciations preserved in the Tintina Trench of west-central Yukon: stratigraphy, paleomagnetism, paleosols, and pollen. Can. J. Earth Sci. 47, 1003-1028.

Duk-Rodkin, A., Barendregt, R.W., White, J.M., Singhroy, V.H., 2001. Geologic evolution of the Yukon River: implications for placer gold. Quat. Int. 82, 5-31.

Duk-Rodkin, A., Barendregt, R.W., Tarnocai, C., Phillips, F.M., 1996. Late tertiary to late quaternary record in the Mackenzie mountains, Northwest territories, Canada: stratigraphy, paleosols, paleomagnetism, and chlorine-36. Can. J. Earth Sci. 33 (6), 875-895.

Ehlers, J., Grube, A., Stephan, H.J., Wansa, S., 2011b. Pleistocene glaciations of North Germany-new results. In: Ehlers, J., Gibbard, P.L., Hughes, P.D. (Eds.), Quaternary Glaciations - Extent and Chronology, a Closer Look, Developments in Quaternary Science, vol. 15. Elsevier, Amsterdam, pp. 149-162.

Ehlers, L., Eissmann, L., Lippstreu, H.-J., Stephan, S., Wansa, 2004. Pleistocene glaciations of North Germany. In: Ehlers, J., Gibbard, P.L. (Eds.), 2004. Quaternary Glaciations. Extent and Chronology Part I: Europe, Developments in Quaternary Science, vol. 2. Elsevier, Amsterdam, pp. 135-146.

Elias, S.A., Hamilton, T.D., Edwards, M.E., Begét, J.E., Krumhardt, A.P., Lavoie, C., 1999. Late Pleistocene environments of the western Noatak basin, northwestern 
Alaska. Geol. Soc. Am. Bull. 111, 769-789.

Fard, A.M., Gruszka, B., 2007. Subglacial Conditions in a Branching Saalian Esker in North-central Poland.

Filonowicz, P., 1980. Objaśnienia Do Mapy Geologicznej Polski W Skali 1:200000, Ark. Kielce [Explanations to the Geological Map of Poland 1: 200 000, Kielce Sheet], p. 143. Warszawa.

Follmer, L.R., Nelson, W.J., 2010. Surfical Geology of Johnston City Quadrangle. Williamson and Franklin Counties, Illinois. Illinois State Geological Survey, Illinois Quadrangle Map. IGQ Pittsburg, SG, 1: 24,000.

Fugitt, F.L., Spahr, P.N., Pavey, R.R., Aden, D.J., Jones, M., Angle, M.P., 2016. Surfical Geology of the Hillsboro $30 \times 60$-mintue Quadrangle in Ohio: Columbus. Ohio Department of Natural Resources, Division of Geological Survey Map SG-2-HIL, scale 1:100,000.

Fulton, R.J., Irving, E., Wheadon, P.M., 1992. Stratigraphy and paleomagnetism of brunhes and matuyama (>790 ka) quaternary deposits at Merritt, British Columbia. Can. J. Earth Sci. 29, 76-92.

Gaigalas, A., Arslanov, K.A., Maksimov, F.E., Kuznetsov, V.Y., Chernov, S.B., 2007. Uranium-Thorium isochron dating results of penultimate (Late Mid-Pleistocene) Interglacial in Lithuania from Mardasavas site. Geologija 57, 21-29.

Gallagher, C., Thorp, M., 1997. The age of the Pleistocene raised beach near Fethard, County Wexford, using infrared stimulated luminescence (IRSL). Ir. Geogr. 30, 68-89.

Gemmell, A.M.D., Murray, A.S., Connell, E.R., 2007. Devensian glacial events in Buchan (NE Scotland): a progress report on new OSL dates and their implications. Quat. Geochronol. 2, 237-242.

Gey, V.P., Kozlov, V.V., Malakhovsky, D.B., 2004. On the age and extent of the maximum Late Pleistocene ice advance along the Baltic-Caspian watershed. In: Ehlers, J., Gibbard, P.L. (Eds.), Quaternary Glaciations - Extent and Chronology. Part 1: Europe, vol. 2. Developments in Quaternary Sciences, pp. 355-358.

Gey, V., Saarnisto, M., Lunkka, J.P., Demidov, I., 2001. Mikulino and Valdai palaeoenvironments in the Vologda area, NW Russia. Glob. Planet. Change 31, 347-366.

Gibbard, P.L., Pasanen, A.H., West, R.G., Lunkka, J.P., Boreham, S., Cohen, K., Rolfe, C., 2009. Late middle pleistocene glaciation in East Anglia, England. Boreas 38, 504-528.

Gibbard, P.L., West, R.G., Andrew, R., Pettit, M., 1992. The margin of a middle pleistocene ice advance at Tottenhill, Norfolk. Engl. Geol. Mag. 129, 59-76.

Gibbard, P.L., West, R.G., Andrew, R., Pettit, M., 1991. Tottenhill, Norfolk (TF 636115). 1991. In: Lewis, S.G., Whiteman, C.A., Bridgland, D.R. (Eds.), Central East Anglia and the Fen Basin - Field Guide, Quaternary Research Association, pp. 131-144. London.

Gillespie, A.R., Clark, D.H., 2011. Glaciations of the sierra Nevada, California, USA. In: Ehlers, J., Gibbard, P.L., Hughes, P.D. (Eds.), 2011, Quaternary Glaciations Extent and Chronology, a Closer Look, Developments in Quaternary Science, vol. 15. Elsevier, Amsterdam, pp. 447-462.

Glapa, H., 1971. Warthezeitliche Eisrandlagen im Gebiet der Letzlinger Heide. Geologie 20, 1087-1110.

Godlewska, A., 2014. Dynamics of the Younger Saalian Ice-sheet in the Marginal Zone in the Krzna and Bug Interfluve in the Light of Lithofacies Analysis. Maria Curie-Sklodowska University Press, Lublin (in Polish, with English summary).

Godlewska, A., Terpiłowski, S., 2012. Transverse, supraglacially derived crevasse infillings in a Pleistocene ice-sheet margin zone (eastern Poland): genesis and sedimentary record. Geomorphology 161, 73-81.

Grichuk, V.P., Zaklinskaya, E.D., Mizerov, B.V., 1971. Excursion Guide on Silts of Cenozoic Deposits of Tomskoe Priob'ye. IGiG SO AN SSSR, Novosibirsk, pp. 1-64 (in Russian).

Grimley, D.A., McKay, E.D., 2004. Surficial Geology of French Village Quadrangle, St. Clair County, IL. Illinois State Geological Survey, Illinois Geologic Quadrangle Map. IGQ French Village-SG, 1:24,000.

Grimley, D.A., Phillips, A.C., 2011. Surficial Geology of St. Clair County, Illinois. Illinois State Geological Survey, Illinois County Geologic Map. ICGM St. Clair-SG, 2 sheets, $1: 62,500$.

D.A.Grimley, Phillips, A.C., 2006. Surficial Geology of Grantfork Quadrangle, Madison County, Illinois. Illinois State Geological Survey, Illinois Geologic Quadrangle Map. IGQ Grantfork-SG, 1:24,000.

Grimley, D.A., Webb, N.D., 2009. Surficial Geology of New Athens East Quadrangle, St. Clair County, Illinois. Illinois State Geological Survey, Illinois Geologic Quadrangle Map, p. 12. IGQ New Athens East-SG, 1:24,000, report.

Grimley, D.A., Phillips, A.C., Follmer, L.R., Wang, H., Nelson, R.S., 2001. Quaternary and environmental geology of the St. Louis Metro East area. In: Malone, D. (Ed.), Guidebook for Field Trip for the 35th Annual Meeting of the North-Central Section of the Geological Society of America, vol. 33. Illinois State Geological Survey, Guidebook, pp. 21-73.

Grimley, D.A., Follmer, L.R., McKay, E.D., 1998. Magnetic susceptibility and mineral zonations controlled by provenance in loess along the Illinois and central Mississippi River valleys. Quat. Res. 49, 24-36.

Grüger, E., 1972. Late Quaternary vegetation development in south-central Illinois. Quat. Res. 2, 217-231.

Gruszka, B., Van Loon, A.J., Zielinski, T., 2006. Bridging the gap in quaternary geology between East and West: the Brodzikowski heritage. Sediment. Geol. 193, $1-5$.

Guobyte, R., Satkunas, J., 2011. Pleistocene glaciations in Lithuania. In: Ehlers, J., Gibbard, P.L. (Eds.), Quaternary Glaciations - Extent and Chronology. Part 1: Europe. Developments in Quaternary Sciences, vol. 2. Elsevier, Amsterdam, pp. $231-246$.
Hamblin, R.J.O., Moorlock, B.S.P., Rose, J., Lee, J.R., Riding, J.B., Booth, S.J., Pawley, S.M., 2005. Revised Pre-Devensian glacial stratigraphy in Norfolk, England, based on mapping and till provenance. Geol. Mijnb. 84, 77-85.

Hicock, S.R., 1990. Last interglacial muir point formation, Vancouver island, British Columbia. Géogr. Physique Quaternaire 44, 337-340.

Hicock, S.R., Lian, O.B., 1995. The Sisters Creek Formation: pleistocene sediments representing a nonglacial interval in southwestern British Columbia at about 18 ka. Can. J. Earth Sci. 32, 758-767.

Hjort, C., Funder, S., 2008. Mountain-derived versus shelf-based glaciations on the western Taymyr peninsula, Siberia. Polar Res. 27, 273-279.

Höfle, H.C., Lade, U., 1983. The stratigraphic position of the lamstedter moraine within the Younger Drenthe substage (middle Saalian). In: Muller, E.H. (Ed.), Glacial Deposits in North-West Europe. AA Balkema Rotterdam, pp. 343-346.

Houmark-Nielsen, M., Demidov, I., Funder, S., Grøsfjeld, K., Kjær, K.H., Larsen, E. Lavrova, N., Lysă, A., Nielsen, J.K., 2001. Early and Middle Valdaian glaciations, ice-dammed lakes and periglacial interstadials in northwest Russia: new evidence from the Pyoza River area. Glob. Planet. Change 31, 215-237.

Huscroft, C.A., 2002. Late Cenozoic History of the Yukon River Valley, Fort Selkirk to the Stevenson Ridge Map Area. PhD thesis. Simon Fraser University, Burnaby, British Columbia.

Huscroft, C.A., Ward, B.C., Barendregt, R.W., Jackson Jr., L.E., Opdyke, N.D., 2004. Pleistocene volcanic damming of Yukon river and the maximum age of the reid glaciation, west-central Yukon. Can. J. Earth Sci. 41, 151-164.

Isayeva, L.L., Kind, N.V., Laukhin, S.A., Kolpakov, V.V., Shofman, I.L., Fainer, Y.B., 1986. The Stratigraphic Scheme of the Quaternary of Central Siberia. Chetvertichnye Oledeneniya Srednei Sibiri. Nauka, Moscow, pp. 4-17.

Jackson, L.E., Andriashek, L.D., Phillips, F.M., 2011. Limits of successive Middle and Late Pleistocene continental ice sheets, interior plains of southern and centra Alberta and adjacent areas. In: Ehlers, J., Gibbard, P.L., Hughes, P.D. (Eds.), 2011, Quaternary Glaciations - Extent and Chronology, a Closer Look, Developments in Quaternary Science, vol. 15. Elsevier, Amsterdam, pp. 575-590.

Johnson, W.H., Follmer, L., Gross, D.L., Jacobs, A.M., 1972. In: Pleistocene stratigraphy of the east-central Illinois. Illinois State Geological Survey Guidebook Series, vol. 9. Illinois State Geological Survey, pp. 1-97.

Kajak, K., 1995. Map of the Quaternary Deposits of Estonia 1:2500000. Eesti Geoloogiakeskus, Tallinn, p. 26 (In Estonian).

Kajak, K., Raukas, A., Hütt, G., 1981. Experience in dating different-aged tills using thermoluminescence method. In: Gaigalas, A., Jevzerov, V., Ivanova, L. Raukas, A., Ruhina, E. (Eds.), Pleistocene Geology in Northwestern Part of the USSR. Kola Branch of the USSR Academy of Sciences, Apatity, pp. 3-11 (in Russian).

Kalm, V., Raukas, A., Rattas, M., Lasberg, K., 2011. Pleistocene glaciations in Estonia. In: Ehlers, J., Gibbard, P.L., Hughes, P.D. (Eds.), Quaternary Glaciations - Extent and Chronology, a Closer Look, Developments in Quaternary Science, vol. 15. Elsevier, Amsterdam, pp. 95-104.

Karabanov, A.K., Matveyev, A.V., 2011. The Pleistocene glaciations in Belarus. In: Ehlers, J., Gibbard, P.L., Hughes, P.D. (Eds.), 2011. Quaternary Glaciations Extent and Chronology: a Closer Look, Developments in Quaternary Science, vol. 15. Elsevier, Amsterdam, pp. 29-35.

Kaufman, D.S., Manley, W.F., Forman, S.L., Layer, P.W., 2001a. Pre-late-Wisconsin glacial history, coastal Ahklun Mountains, southwestern Alaska - new amino acid, thermoluminescence, and 40Ar/39Ar results. Quat. Sci. Rev. 20, 337-352.

Kaufman, D.S., Manley, W.F., Wolfe, A.P., Hu, F.S., Preece, S.J., Westgate, J.A., Forman, S.L., 2001b. The last interglacial to glacial transition, Togiak Bay, southwestern Alaska. Quat. Res. 55, 190-202.

Kind, N.V., 1974. Late Quaternary Geochronology According to Isotopes Data. Nauka, Moscow, p. 255 (in Russian).

Kind, N.V., Leonov, B.N., 1982. The Anthropocene of Taimyr (Antropogen Taimyra), Nauke, Moscow, p. 184 (in Russian).

King, J.E., Saunders, J.J., 1986. Geochelone in Illinois and the Illinoian-Sangamonian vegetation of the type region. Quat. Res. 25, 89-99.

Kjaer, K.H., Larsen, E., Funder, S., Demidov, I., Jensen, M., Hakansson, L., Murray, A. 2006. Eurasian ice-sheet interaction in northwestern Russia throughout the late Quaternary. Boreas 35, 444-475.

Korsakova, O.P., 2009. Pleistocene marine deposits in the coastal areas of Kola Peninsula (Russia). Quat. Int. 206, 3-15.

Krebetschek, M.R., Degering, D., Alexowsky, W., 2008. Ifrarot-RadiofluoreszenzAlter (IR-RF) unter-saalezeitlicher Sedimente Mittel-und Ostdeutschlands, vol. 159. Zeitschrift der Deutschen Gesellschaft für Geowissenschaften, pp. $133-140$.

Krzyszkowski, D., 2002. Sedimentary successions in ice-marginal fans of the Late Saalian glaciation, southwestern Poland. Sediment. Geol. 149, 93-109.

Lang, J., Winsemann, J., Steinmetz, D., Polom, U., Pollok, L., Böhner, U., Serangeli, J., Brandes, C., Hampel, A., Winghart, S., 2012. The Pleistocene of Schöningen, Germany: a complex tunnel valley fill revealed from 3D subsurface modelling and shear wave seismics. Quat. Sci. Rev. 39, 86-105.

Larsen, E., Kjær, K.H., Jensen, M., Demidov, I., Håkansson, L., Paus, A., 2006. Early Weichselian palaeoenvironments reconstructed from a mega-scale thrust-fault complex, Kanin Peninsula, northwestern Russia. Boreas 35, 476-492.

Lauhkin, S., Gaigalas, A., 2008. On the palaeoclimatic structure of MIS-5 analogues in the midland part of Siberia (palaeobotanical and U/Th dating data). Geologija 50, 176-187.

Leonard, A.B., Frye, J.C., 1960. Wisconsinan molluscan faunas of the Illinois Valley region Ill. Geol. Surv. Circ. 304, 32.

Leonard, A.B., Frye, J.C., Johnson, W.H., 1971. Illinoian and kansan molluscan faunas 
of Illinois ill. State Geol. Surv. Circ. 461, 23.

Levina, T.P. 1964. Quaternary Pollen Spectra from the Proglacial Zone of the Samarovo Ice Sheet (The Yenissei Catchment). Sistematika I Metody Izucheniya Iskopayemykh Pyltsy I Spor. Nauka, Moscow, pp. 208-217.

Lewis, S.G., Rose, J., 1991. Tottenhill, Norfolk (TF 639 120). In: Lewis, S.G., Whiteman, C.A., Bridgland, D.R. (Eds.), Central East Anglia and the Fen Basin, Field Guide. Quaternary Research Association, London, pp. 145-148.

Lian, O.B., Hu, J., Huntley, D.J., Hicock, S.R., 1995. Optical dating studies of Quaternary organic-rich sediments from southwestern British Columbia and northwestern Washington State. Can. J. Earth Sci. 32, 1194-1207.

Lindner, L., Astapova, S.D., 2000. The age and geological setting of Pleistocene glacigenic beds around the border between Poland and Belarus. Geol. Quart. 44, 187-198.

Lindner, L., Marks, L., 1994. Pleistocene glaciations and interglacials in the Vistula, the oder, and the Elbe drainage basins (central European Lowland). Acta Geol. Pol. 44, 153-165.

Lindner, L., Marciniak, B., Sanko, A.A., Khursevich, G.K., 2001. The age of the oldest Scandinavian glaciations in mid-eastern Poland and southwestern Belarus. Geol. Quart. 45, 373-386.

Lippstreu, L., Brose, F., Marcinek, J., 1995. Brandenburg. Das Quartär Deutschlands, pp. 116-147.

Litt, T., Behre, K.-E., Meyer, K.-D., Stephan, H.-J., Wansa, S., 2007. Stratigraphische Begriffe für das Quartär des norddeutschen Vereisungsgebietes. Eiszeitalt. Ggw. $56,7-65$.

Loseva, E.I., Duryagina, D.A., 1983. Palaeobotanic evidence for stratigraphy of Cenozoic sediments of the central Pai-Hoi. Tr. Inst. Geol. Komi Branch Acad. Sci. Syktyvkar, USSR 43, 56-68 (in Russian).

Ludwikowska-Kędzia, M., Pawelec, H., Adamiec, G., 2015. Sedimentological interpretation and stratigraphical position of glacigenic deposits in the Napęków area (Holy Cross Mountains, Poland). Geologos 21, 261-284.

Lunkka, J.P., Saarnisto, M., Gey, V., Demidov, I., Kiselova, V., 2001. Extent and age of the Last glacial maximum in the southeastern sector of the scandinavian ice sheet. Glob. Planet. Change 31, 407-425.

Luethgens, C., Boese, M., Preusser, F., 2011. Age of the Pomeranian ice-margina position in northeastern Germany determined by Optically Stimulated Luminescence (OSL) dating of glaciofluvial sediments. Boreas 40, 598-615.

Lüthgens, C., Böse, M., Krbetschek, M., 2010a. On the age of the young morainic morphology in the area ascribed to the maximum extent of the Weichselian glaciation in north-eastern Germany. Quat. Int. 222, 72-79.

Lüthgens, C., Krbetschek, M.R., Böse, M., Fuchs, M.C., 2010b. Optically stimulated luminescence dating of fluvioglacial (sandur) sediments from north-eastern Germany. Quat. Geochron 5, 237-243.

Lüthgens, C., Böse, M., Lauer, T., Krbetschek, M., Strahl, J., Wenske, D., 2010c. Timing of the last interglacial in Northern Europe derived from optically stimulated Luminescence (OSL) dating of a terrestrial Saalian-Eemian-Weichselian sedimentary sequence in NE-Germany. Quat. Int. 241, 79-96.

Maksimov, F.E., Laukhin, S.A., Arslanov, K.A., Kuznetsov, V.-Y., Shilova, G.N., Chernov, S.B., Zherebtsov, IE. Levchenko, S.B., 2010. The first uranium-thorium dating of the middle neopleistocene peat in West Siberia. Dokl. Earth Sci. 433 915-919.

Mangerud, J., Gosse, J., Matiouchkov, A., Dolvik, T., 2008. Glaciers in the polar urals, Russia, were not much larger during the Last global glacial maximum than today. Quat. Sci. Rev. 27, 1047-1057.

Mangerud, J., Astakhov, V., Svendsen, J.I., 2002. The extent of the Barents-Kara ice sheet during the Last glacial maximum. Ouat. Sci. Rev. 21, 111-119.

Mangerud, J., Astakhov, V.I., Murray, A., Svendsen, J.I., 2001. The chronology of a large ice-dammed lake and the Barents-Kara Ice Sheet advances, Northern Russia. Glob. Planet. Change 31, 321-336.

Mangerud, J., Svendsen, J.I., Astakhov, V.I., 1999. Age and extent of the Barents and Kara ice sheets in Northern Russia. Boreas 28, 46-80.

McClenaghan, B., Seaman, A., Parkhill, M., Pronk, A., 2014. Till geochemical signatures associated with the Sisson W-Mo deposit, New Brunswick, Canada. Atl. Geol. 50, 116-137.

McCarroll, D., Stone, J.O., Ballantyne, C.K., Scourse, J.D., Fifield, L.K., Evans, D.J. Hiemstra, J.F., 2010. Exposure-age constraints on the extent, timing and rate of retreat of the last Irish Sea ice stream. Quat. Sci. Rev, 29, 1844-1852.

McKay, D., Berg, R.C., 2008. April. Optical ages spanning two glacial-interglacia cycles from deposits of the ancient Mississippi River, north-central Illinois. In: Geol. Soc. Am. Abstr, vol. 40, p. 78.

McKay, E.D., Berg, R.C., Hansel, A.K., Kemmis, T.J., Stumpf, A.J., 2008. Quaternary Deposits and History of the Ancient Mississippi River Valley, North-central Illinois. Illinois State Geological Survey Guidebook, 35, Illinois State Geological Survey, Champaign, Illinois, pp. 1-98.

Meng, S., Wansa, S., 2008. Sedimente und Prozesse am Außenrand der Saale-Vereisung südwestlich von Halle (Saale) [Sediments and processes at the borderline of Saalian glaciation southwest of Halle (Saale)]. Z. Dtsch. Ges. für Geowiss. 159, 205-220.

Mirecki, J.E., Miller, B.B., 1994. Aminostratigraphic correlation and geochronology of two Quaternary loess localities, central Mississippi Valley. Quat. Res. 41, 289-297.

Möller, P., Hjort, C., Alexanderson, H., Sallaba, F., 2011. Glacial history of the Taymy peninsula and the severnaya Zemlya Archipeligo, Arctic Russia. In: Ehlers, J. Gibbard, P.L., Hughes, P.D. (Eds.), Quaternary Glaciations - Extent and Chronology, a Closer Look, Developments in Quaternary Science, vol. 15. Elsevier, Amsterdam, pp. 373-384.
Möller, P., Fedorov, G., Pavlov, M., Seidenkrantz, M.-S., Sparrenbom, C., 2008. Glacial and palaeoenvironmental history of the cape chelyuskin area, Arctic Russia. Polar Res. 27, 222-248.

Möller, P., Lubinski, D.J., Ingólfsson, O., Forman, S.L., Seidenkrantz, M.-S., Bolshiyanov, D.Y., Lokrantz, H., Antonov, O., Pavlov, M., Ljung, K., Zeeberg, J.J., Andreev, A., 2007. Erratum to: severnaya Zemlya, Arctic Russia: a nucleation area for Kara sea ice sheets during the middle to Late quaternary [Quat. Sci. Rev. 25, 2894-2936] Quat. Sci. Rev. 26, 1149-1191.

Möller, P., Lubinski, D.J., Ingólfsson, Ó., Forman, S.L., Seidenkrantz, M.-S., Bolshiyanov, D.Y., Lokrantz, H., Antonov, O., Pavlov, M., Ljung, K., Zeeberg, J.J., Andreev, A., 2006. Severnaya Zemlya, Arctic Russia: a nucleation area for Kara sea ice sheets during the middle to Late quaternary. Quat. Sci. Rev. 25, 2894-2936.

Molodkov, A., 2001. ESR dating evidence for early man at a Lower Palaeolithic cavesite in the Northern Caucasus as derived from terrestrial mollusc shells. Quat. Sci. Rev. 20, 1051-1055.

Molodkov, A.N., Bolikhovskaya, N.S., 2009. Climate change dynamics in Northern Eurasia over the last $200 \mathrm{ka}$ : evidence from mollusc-based ESR-chronostratigraphy and vegetation sucessions of the loess-palaeosol records. Quat. Int. 201, $67-76$.

Molodkov, A.N., Bolikhovskaya, N.S., 2002. Eustatic sea-level and climate changes over the last $600 \mathrm{ka}$ as derived from mollusc-based ESR-chronostratigraphy and pollen evidence in Northern Eurasia. Sediment. Geol. 150, 185-201.

Murray, A., Buylaert, J.-P., Henriksen, M., Svendsen, J.-I., Mangerud, J., 2008. Testing the reliability of quartz OSL ages beyond the Eemian. Radiat. Meas. 43, 776-780.

Murray, A.S., Svendsen, J.I., Mangerud, J., Astakhov, V.I., 2007. Quartz OSL age of an Eemian site on the Sula River, northern Russia. Quat. Geochron 2, 102-109.

Nazarov, D.V., 2007. New data on quaternary sediments in the central part of the West Siberian Arctic. Reg. Geol. i Metallog. 30/31, 213-221 (in Russian).

Nazarov, D., Henriksen, M., 2010. New Data on Quaternary Stratigraphy of the Lower Yenissei Area, Arctic Siberia. APEX Fourth International Conference and Workshop. University of Iceland, Höfn, p. 62.

Nelson, WJ 2013. Surficial geology of Carbondale quadrangle, Jackson and Williamson Counties, Illinois. Illinois State Geological Survey, Illinois Geologic quadrangle Map. IGQ Carbondale-SG, 1:24,000.

O'Cofaigh, C.Ó., Telfer, M.W., Bailey, R.M., Evans, D.J., 2012. Late Pleistocene chronostratigraphy and ice sheet limits, southern Ireland. Quat. Sci. Rev. 44, 160-179.

Occhietti, S., Long, B., Clet, M., Boespflug, X., Sabeur, N., 1995. Séquence de la transition Illinoien-Sangamonien: forage IAC-91 de l'île aux Coudres, estuaire moyen du Saint-Laurent, Québec. Can. J. Earth Sci. 32, 1950-1964.

Pavlovskaya, I.E.P., 2000. The Middle and Late Pleistocene glacial-interglacial succession of eastern Belarus. Geol. Quart. 44, 199-204.

Peeters, J., Busschers, F.S., Stouthamer, E., Bosch, J.H.A., Van den Berg, M.W., Wallinga, J., Versendaal, A.J., Bunnik, F.P.M., Middelkoop, H., 2016. Sedimentary architecture and chronostratigraphy of a late Quaternary incised-valley fill: a case study of the late Middle and Late Pleistocene Rhine system in The Netherlands. Quat. Sci. Rev. 131, 211-236.

Philips, A.C., 2008. Surfical Geology of New Athens West Quadrangle. Munroe and St. Claire Counties, Illinois, Illinois State Geological Survey, 1:10,000 (2 sheets).

Phillips, A.C., 2004. Surficial Geology of Collinsville Quadrangle, Madison and St. Clair Counties, Illinois. Illinois State Geological Survey. Illinois Preliminary Geologic Map, IPGM Collinsville-SG scale 1:24,000.

Phillips, F.M., Zreda, M., Plummer, M.A., Elmore, D., Clark, D.H., 2009. Glacial geology and chronology of Bishop Creek and vicinity, eastern Sierra Nevada, California. Geol. Soc. Am. Bull. 121, 1013-1033.

Phillips, W.M., Hall, A.M., Mottram, R., Fifield, L.K., Sugden, D.E., 2006. Cosmogenic $10 \mathrm{Be}$ and $26 \mathrm{Al}$ exposure ages of tors and erratics, Cairngorm Mountains, Scotland: timescales for the development of a classic landscape of selective linear glacial erosion. Geomorphology 73, 222-245.

Preece, S.J., Pearce, N.J., Westgate, J.A., Froese, D.G., Jensen, B.J.L., Perkins, W.T., 2011 Old Crow tephra across eastern Beringia: a single cataclysmic eruption at the close of Marine Isotope Stage 6. Quat. Sci. Rev. 30, 2069-2090.

Rattas, M. Kalm, V. Kihno, K. Liivrand, E, Tinn, O, Tänavsuu-Milkeviciene, K. Sakson, M., 2010. Chronology of Late Saalian and Middle Weichselian episodes of ice-free lacustrine sedimentation recorded in the Arumetsa section, southwestern Estonia. Est. J. Earth Sci. 59, 125-140.

Raukas, A., 1995. Properties, origin and stratigraphy of Estonian tills. Glacial Deposits North-East Eur. 93-101.

Raukas, A., Kajak, K., 1997. Quaternary cover. Geol. mineral Resour. Est. 125-136.

Rose, J., 2009. Early and middle pleistocene landscapes of eastern England. Proc. Geol. Assoc. 120, 3-33.

Roskosch, J., Winsemann, J., Polom, U., Brandes, C., Tsukamoto, S., Weitkamp, A., Bartholomäus, W.A., Henningsen, D., Frechen, M., 2015. Luminescence dating of ice-marginal deposits in northern Germany: evidence for repeated glaciations during the Middle Pleistocene (MIS 12 to MIS 6). Boreas 44, 103-126.

Salamon, T., 2014. Basal till and subglacial conditions at the base of the Upper Odra ice lobe (southern Poland) during the Odranian (Saalian) Glaciation. Geol. Quart. 58, 779-794.

Scourse, J.D., Evans, D.J.A., Hiemstra, J., McCarroll, D., Rhodes, E., 2004. Late Devensian Glaciation of the Isles of Scilly. Quat. Res. Assoc. Research Fund Report. Quaternary Newsletter, vol. 102, pp. 49-54.

Sier, M.J., Peeters, J., Dekkers, M.J., Parés, J.M., Chang, L., Busschers, F.S., Cohen, K.M., Wallinga, J., Bunnik, F.P., Roebroeks, W., 2015. The Blake Event recorded near the 
Eemian type locality - a diachronic onset of the Eemian in Europe. Quat. Geochron 28, 12-28.

Stauch, G., Gualtieri, L., 2008. Late Quaternary glaciations in northeastern Russia. J. Quat. Sci. 23, 545-558.

Stauch, G., Lehmkuhl, F., 2011. Extent and timing of quaternary glaciations in the Verkhoyansk mountains. In: Ehlers, J., Gibbard, P.L., Hughes, P.D. (Eds.), Quaternary Glaciations - Extent and Chronology, a Closer Look, Developments in Quaternary Science, vol. 15. Elsevier, Amsterdam, pp. 877-881.

Stauch, G., Lehmkuhl, F., 2010. Quaternary glaciations in the Verkhoyansk mountains, Northeast Siberia. Quat. Res. 74, 145-155.

Stauch, G., Lehmkuhl, F., Frechen, M., 2007. Luminesence chronology from the Verkhoyansk mountains (North-Eastern Siberia). Quat. Geochron 2, 255-259.

Stea, R.R., Seaman, A.A., Pronk, T., Parkhill, M.A., Allard, S., Utting, D., 2011. The appalachian glacier complex in Maratime Canada. In: Ehlers, J., Gibbard, P.L., Hughes, P.D. (Eds.), Quaternary Glaciations - Extent and Chronology, a Closer Look, Developments in Quaternary Science, vol. 15. Elsevier, Amsterdam, pp. 631-660.

Stea, R.R., Piper, D.J.W., Fader, G.B.J., Boyd, R., 1998. Wisconsinan glacial and sealevel history of Maritime Canada and the adjacent continental shelf: a correlation of land and sea events. Geol. Soc. Am. Bull. 110, 821-845.

Stea, R.R., Mott, R.J., Belknap, D.F., Radtke, U., 1992. The pre-late Wisconsinan chronology of Nova Scotia, Canada. Geol. Soc. Am. Spec. Pap. In: Clark, P.U., Lea, P.D. (Eds.), The Last Interglaciation/glaciation Transition in North America, vol. 270, pp. 185-206.

Stepanov, A.N., 1974. Stratigraphy and Sedimentary Environments of the Upper Cenozoic of the Pechora-kama Interfluve. Resume of PhD thesis. Geological Faculty of Moscow University, p. 34 (in Russian).

Stephan, H.J., 1980. Glazialgeologische Untersuchungen im südlichen Geestgebiet Dithmarschens.

Stroeven, A.P., Fabel, D., Margold, M., Clague, J.J., Xu, S., 2014. Investigating absolute chronologies of glacial advances in the NW sector of the Cordilleran Ice Sheet with terrestrial $\beta$ cosmogenic nuclides. Quat. Sci. Rev. 92, 429-443.

Stroeven, A.P., Fabel, D., Codilean, A.T., Kleman, J., Clague, J.J., MiguensRodriguez, M., Xu, S., 2010. Investigating the glacial history of the northern sector of the Cordilleran Ice Sheet with cosmogenic 10Be concentrations in quartz. Quat. Sci. Rev. 29, 3630-3643.

Stumpf, A.J., Dey, W.S., 2012. Understanding the Mahomet Aquifer: Geological, Geophysical, and Hydrogeological Studies in Champaign County and Adjacent Areas. Prairie Research Institute, Illinois State Geological Survey, Champaign, Illinois, p. 350.

Svendsen, J.I., Alexanderson, H., Astakhov, V.I., Demidov, I., Dowdeswell, J.A., Funder, S., Gataullin, V., Henriksen, M., Hjort, C., Houmark-Nielsen, M., Hubberten, H.W., 2004. Late Quaternary ice sheet history of northern Eurasia. Quat. Sci. Rev. 23, 1229-1271.

Szabo, J.P., Totten, S.M., 1995. Multiple pre-Wisconsian glaciations along the northwestern edge of the Allegheny Plateau in Ohio and Pennsylvania. Can. J. Earth Sci. 32, 2081-2089.

Teed, R., 2000. A > 130,000-year-long pollen record from Pittsburg Basin, Illinois. Quat. Res. 54, 264-274.

Thomas, J.P., Murray, A.S., Kjaer, H., Funder, S., Larsen, E., 2006. Optically Stimulated Luminescence (OSL) dating of glacial sediments from Arctic Russia - depositional bleaching and methodological aspects. Boreas 35, 587-599.

Törnqvist, T.E., Wallinga, J., Busschers, F.S., 2003. Timing of the last sequence boundary in a fluvial setting near the highstand shoreline - insights from optical dating. Geology 31, 279-282.

Törnqvist, T.E., Wallinga, J., Murray, A.S., De Wolf, H., Cleveringa, P., De Gans, W., 2000. Response of the Rhine-Meuse system (west-central Netherlands) to the last Quaternary glacio-eustatic cycles: a first assessment. Glob. Planet. Change
27, 89-111.

Van Gijssel, K., 1987. A lithostratigraphic and glaciotectonic reconstruction of the Lamstedt Moraine, Lower Saxony (FRG). In: Houmark-Nielsen, M. (Ed.), Tills and Glaciotectonics. Boreas, vol. 18, pp. 145-155.

Velichko, A.A., Faustova, M.A., Pisareva, V.V., Gribchenko, Y.N., Sudakova, N.G., Lavrentiev, N.V., 2011. Glaciations of the East European Plain: distribution and chronology. In: J Ehlers, J., Gibbard, P.L., Hughes, P.D. (Eds.), Quaternary Glaciations - Extent and Chronology, a Closer Look, Developments in Quaternary Science, vol. 15. Elsevier, Amsterdam, pp. 337-359.

von Poblozki, B., 1995. Quaternary geology of the Altmark region. In: Ehlers, J., Kozarski, S., Gibbard, P.L. (Eds.), 1995. Glacial Deposits in North-East Europe. Balkema, Rotterdam, Brookfield, pp. 473-484.

Wallinga, J., Törnqvist, T.E., Busschers, F.S., Weerts, H.J., 2004. Allogenic forcing of the late Quaternary Rhine-Meuse fluvial record: the interplay of sea-level change, climate change and crustal movements. Basin Res. 16, 535-547.

Wang, H., Follmer, L.R., Liu, J.C.L., 2000. Isotope evidence of paleo-El Niño-Southern Oscillation cycles in loess-paleosol record in the central United States. Geology 28, 771-774.

Ward, B.C., Bond, J.D., Froese, D.G., Jensen, B., 2008. Old Crow tephra (140 \pm 10 ka) constrains penultimate Reid glaciation in central Yukon Territory. Quat. Sci. Rev. 27, 1909-1915.

Waythomas, C.F., Lea, P.D., Walter, R.C., 1993. Stratigraphic context of Old Crow tephra, Holitna Lowland, interior southwest Alaska. Quat. Res. 40, 20-29.

Webb, N.D., Grimley, D.A., Phillips, A.C., Fouke, B.W., 2012. Origin of glacial ridges (OIS 6) in the Kaskaskia Sublobe, southwestern Illinois, USA. Quat. Res. 78, $341-352$.

Westgate, J.A., Hamilton, T.D., Gorton, M.P., 1983. Old Crow tephra: a new late Pleistocene stratigraphic marker across north-central Alaska and western Yukon Territory. Quat. Res. 19, 38-54.

Włodarski, W., Godlewska, A., 2016. Sedimentary and structural evolution of a Pleistocene small-scale push moraine in eastern Poland: new insight into paleoenvironmental conditions at the margin of an advancing ice lobe. Quat. Sci. Rev. 146, 300-321.

Wood, J.R., Forman, S.L., Pierson, J., Gomez, J., 2010. New insights on Illinoian deglaciation from deposits of Glacial Lake Quincy, central Indiana. Quat. Res. 73, $374-384$.

Zarkhidze, V.S., 1981. Stratigraphy and correlation of Pliocene and Pleistocene deposits. In: Kamaletdinov, M.A., Yakhimovich, V.L. (Eds.), Pliotsen I Pleistotsen Volgo-uralskoi Oblasti. Nauka, Moscow, pp. 7-28.

Zarkhidze, V.S., 1972. The Padimei formation of the western and central TimanUralian Region. In: Yakhimovich, V.L. (Ed.), Voprosy Stratigrafii I Korrelatsii Pliotsenovykh I Pleistotsenovykh Otlozheniy Ssevernoi I Yuzhnoi Chastei Preduralya, vol. 1. Bashkir Branch of Academy of Sciences of USSR, Ufa, pp. 56-66 (in Russian).

Zech, M., Andreev, A., Zech, R., Müller, S., Hambach, U., Frechen, M., Zech, W., 2010. Quaternary vegetation changes derived from a loess-like permafrost palaosol sequence in northeast Siberia using alkane biomarker and pollen analyses. Boreas 39, 540-555.

Zech, M., Zech, R., Zech, W., Glaser, B., Brodowski, S., Amelung, W., 2008. Characterisation and palaeoclimate of the loess-like permafrost palaeosol sequence in NE Siberia. Geoderma 143, 281-295.

Zhu, H., Baker, R.G., 1995. Vegetation and climate of the last glacial-interglacial cycle in southern Illinois, USA. J. Paleolim 14, 337-354.

Zubakov, V.A., 1972a. Recent Sediments of the West Siberian Lowland. Nedra, Leningrad, p. 312 (in Russian).

Zubakov, V.A., 1972b. Anthropogene Deposits of the West Siberian Lowland. Nedsra, Leningrad, p. 312 (in Russian). 